\title{
Empirical evidence on explicit and implicit corporate tax burdens : three studies
}

Citation for published version (APA):

Janssen, J. B. P. E. C. (2003). Empirical evidence on explicit and implicit corporate tax burdens : three studies. [Doctoral Thesis, Maastricht University]. Universiteit Maastricht. https://doi.org/10.26481/dis.20031218jj

Document status and date:

Published: 01/01/2003

DOI:

10.26481/dis.20031218jj

Document Version:

Publisher's PDF, also known as Version of record

\section{Please check the document version of this publication:}

- A submitted manuscript is the version of the article upon submission and before peer-review. There can be important differences between the submitted version and the official published version of record.

People interested in the research are advised to contact the author for the final version of the publication, or visit the DOI to the publisher's website.

- The final author version and the galley proof are versions of the publication after peer review.

- The final published version features the final layout of the paper including the volume, issue and page numbers.

Link to publication

\footnotetext{
General rights rights.

- You may freely distribute the URL identifying the publication in the public portal. please follow below link for the End User Agreement:

www.umlib.nl/taverne-license

Take down policy

If you believe that this document breaches copyright please contact us at:

repository@maastrichtuniversity.nl

providing details and we will investigate your claim.
}

Copyright and moral rights for the publications made accessible in the public portal are retained by the authors and/or other copyright owners and it is a condition of accessing publications that users recognise and abide by the legal requirements associated with these

- Users may download and print one copy of any publication from the public portal for the purpose of private study or research.

- You may not further distribute the material or use it for any profit-making activity or commercial gain

If the publication is distributed under the terms of Article $25 \mathrm{fa}$ of the Dutch Copyright Act, indicated by the "Taverne" license above, 


\section{Empirical Evidence on Explicit and Implicit Corporate Tax Burdens:}

Three Studies 
ISBN: 90-9017484-2

C 2003, B. Janssen

All rights reserved. No part of this publication may be reproduced, stored in a retrieval system, or transmitted in any form or by any means of electronic, mechanical, photocopying, recording, or otherwise, without the prior written permission of the author. 


\title{
Empirical Evidence on Explicit and Implicit Corporate Tax Burdens:
}

\author{
Three Studies
}

\section{PROEFSCHRIFT}

ter verkrijging van de graad van doctor aan de Universiteit Maastricht, op gezag van de Rector Magnificus, Prof. dr. A.C. Nieuwenhuijzen Kruseman, volgens het besluit van het College van Decanen, in het openbaar te verdedigen op donderdag 18 december 2003 om 16.00 uur

door

Boudewijn Janssen 


\section{Promotor:}

Prof. dr. W.F.J. Buijink (Universiteit van Tilburg)

\section{Beoordelingscommissie:}

Prof. dr. R.H.G. Meuwissen RA (voorzitter)

Prof. dr. J.G.A. van Mierlo

Prof. dr. R.G.A. Vergoossen RA 


\section{acknowledgements}

During the process of writing a dissertation it is sometimes difficult to stay focused on the final goal, that is, to publish this booklet. Often this goal is obscured by all kinds of other activities, either of a professional or of a personal nature. However, when the end is near, the pace of the work on the dissertation increases and other concerns are (temporarily) set aside. Although I am pleased to have finished this dissertation, I am looking forward to unravel further mysteries which life holds.

In writing this dissertation, I owe gratitude to a lot of people. Thanks, first of all, to David Guenther who introduced me to the subject area of tax accounting during his sabbatical visit at Universiteit Maastricht. A sincere appreciation of gratitude is owed to Willem Buijink, who was willing to accompany me on the road towards completion of this dissertation. I thank him for being there to answer all those (sometimes silly) questions I put forward to him.

I also would like to thank all former and current colleagues at the Department of Accounting and Information Management of Universiteit Maastricht, as well as colleagues at other institutions, especially The University of Arizona.

Furthermore, I would like to thank family and friends in helping me write this dissertation, with a special note of thanks to Jim and Sandra. For her frontline assistance in helping answering all kind of queries I put to her, thanks to Yvonne.

Last, but not least, thanks to those special persons in my life (in alphabetical order): Alexander, Annet, and Irene.

Boudewijn Janssen 



\section{contents}

\section{chapter 1}

Introduction

1.1 Introduction 1

1.2 Taxes 4

1.2.1 Overview 4

1.2.2 Income taxes 4

1.2.3 Payroll taxes 5

1.2.4 Other direct taxes 5

1.2.5 Indirect taxes 6

1.2.6 Value added taxes/sales taxes 6

1.2.7 Duties/excises 6

1.2.8 Other indirect taxes 6

1.2.9 Taxes: conclusion $\quad 7$

1.3 Tax research fields focusing on corporate income taxes 7

1.3.1 Overview 7

$\begin{array}{lll}1.3 .2 & \text { Economics } & 7\end{array}$

$\begin{array}{lll}1.3 .3 & \text { Business } & 8\end{array}$

1.3.4 Legal 8

1.4 Tax research domains in accounting 9

1.4.1 Overview 9

1.4.2 Tax compliance 9

1.4.3 Tax planning 9

$\begin{array}{lll}1.4 .4 & \text { Tax policy } & 10\end{array}$

$\begin{array}{lll}1.5 & \text { Dissertation topic } & 10\end{array}$

$\begin{array}{lll}1.6 & \text { Conclusion } & 12\end{array}$

\section{chapter 2}

Evidence of the Effect of Domicile on Corporate Average Effective Tax Rates in the European Union

2.1 Introduction

2.2 Motivation, ETR measurement, financial accounting issues, and previous research

2.2.1 Motivation and ETR measurement 14

2.2.2 Within-EU accounting related ETR measurement issues 17

2.2.3 Average ETRs: prior cross-country research 19

2.3 Methodology: measurement of the average ETR and sample 20

$\begin{array}{ll}2.3 .1 & \text { Average ETR } \\ \end{array}$ 
$\begin{array}{lll}2.3 .2 & \text { Sample } & 21\end{array}$

2.4 Results 23

2.4.1 Statutory tax rates (STRs) in EU member states 23

2.4.2 Average ETRs in the EU member states 26

2.5 Additional analyses 28

2.5.1 Alternative ETRs 28

$\begin{array}{lll}2.5 .2 & \text { STRs } & 29\end{array}$

2.5.3 Different sets of countries 29

$\begin{array}{lll}2.6 & \text { Conclusion } & 29\end{array}$

\section{chapter 3}

Determinants of the Variability of Corporate Effective Tax Rates (ETRs): Evidence for the Netherlands

3.1 Introduction and motivation 31

3.2 Background, previous research, and hypotheses 32

$\begin{array}{lll}3.2 .1 & \text { Background } & 32\end{array}$

3.2.2 Previous research 33

3.2.2.1 Size. 33

3.2.2.2 Other determinants and control variables. $\quad 34$

3.2.3 Development of hypotheses 36

3.2.4 Discussion 37

3.3 ETRs, the financial accounting treatment of company income tax in The Netherlands, and the relevant statutory company tax rate $\quad 38$

3.3.1 Financial accounting treatment of company income tax in $\begin{array}{ll}\text { The Netherlands } & 38\end{array}$

3.3.2 Relevant statutory corporate income tax rate 39

3.4 Research methods: data, sample, model, and variables 39

3.4.1 The REACH data file 39

3.4.2 Sample selection 39

3.4.3 Multivariate model and variable definitions $\quad 40$

$\begin{array}{ll}3.4 .3 .1 \mathrm{Model} . & 40\end{array}$

3.4.3.2 Calculation of ETRs. 41

3.4.3.3 Estimation procedure. $\quad 42$

3.5 Results 43

3.5.1 Descriptive and univariate results 43

3.5.2 OLS regression results 45

3.5.3 Sensitivity analyses $\quad 46$

3.5.3.1 Rank regression (RR) results. $\quad 46$

$\begin{array}{ll}\text { 3.5.3.2 Other sensitivity analyses. } & 47\end{array}$

3.6 Summary and conclusion $\quad 48$

$\begin{array}{ll}\text { Appendices } & 49\end{array}$ 


\section{chapter 4}

Implicit Taxes in the Corporate Sector:

Evidence for the European Union

4.1 Introduction 61

4.2 Background and hypotheses 62

4.2.1 Background 62

4.2.2 Hypotheses 64

4.2.2.1 Product and factor market frictions. 64

4.2.2.2 Tax rate differences. $\quad 65$

4.2.2.3 Risk. $\quad 66$

4.3 Research method $\quad 66$

$\begin{array}{lll}\text { 4.3.1 Data } & 66\end{array}$

4.3.2 Model(s) and variables $\quad 67$

$\begin{array}{lll}4.4 & \text { Results } & 71\end{array}$

4.4.1 Descriptive and univariate results 71

$\begin{array}{ll}\text { 4.4.2 Multivariate analysis } & 74\end{array}$

$\begin{array}{lll}4.4 .3 & \text { Sensitivity analyses } & 75\end{array}$

$\begin{array}{lll}4.5 & \text { Conclusion } & 78\end{array}$

$\begin{array}{ll}\text { Appendices } & 79\end{array}$

\section{chapter 5}

Conclusion

$\begin{array}{lll}5.1 & \text { Introduction } & 91\end{array}$

$\begin{array}{lll}5.2 & \text { Summary } & 91\end{array}$

5.3 The use of financial statement data 95

5.4 Strengths and weaknesses 96

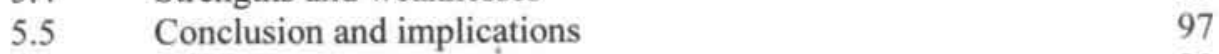

5.6 Directions for future research 98

$\begin{array}{ll}\text { references } & 101\end{array}$

summary in Dutch 111

$\begin{array}{ll}\text { curriculum vitae } & 117\end{array}$ 



\section{chapter 1}

\section{Introduction}

\subsection{Introduction}

The goal of this dissertation is to examine (determinants of) explicit and implicit corporate income tax burdens in the Netherlands and the European Union.

This dissertation consists of three studies:

- An empirical study of the explicit corporate tax burdens on companies domiciled in the European Union;

- An empirical study of the determinants of explicit corporate tax burdens on companies domiciled in the Netherlands;

- An empirical study of the implicit corporate tax burden on companies domiciled in the European Union.

The purpose of the first study is to assess the between-country differences in corporate tax burdens within the European Union, using financial statement information. Earlier research has either tended to focus on single-country observations and/or to use modeling to estimate tax burdens. The current study uses tax burdens as reported in financial statements, i.e., attempts to measure the actual tax burden in several countries.

In the second study the purpose is to identify factors affecting corporate tax burdens between companies in the Netherlands.

The purpose of the third study is to investigate implicit taxes (Scholes and Wolfson 1992) in a corporate setting in the European Union. Prior corporate setting research is only available in a U.S. setting. 
To place the three empirical studies of this dissertation in context, this chapter discusses the general background (see Figure 1.1), whereas specific backgrounds are discussed in each empirical chapter. This chapter continues along the following lines. Section 1.2 describes different types of taxes, which are available to lawmakers in general and explains the relevance of these taxes within the context of this dissertation. In the following section, 1.3, the different tax research fields are introduced along with the characteristics of these research fields. Section 1.4 explains the different research domains and the positioning of these in tax research. Section 1.5 continues with the topics addressed in the empirical studies in this dissertation. Section 1.6 concludes this chapter. 
Figure 1.1 Tax research

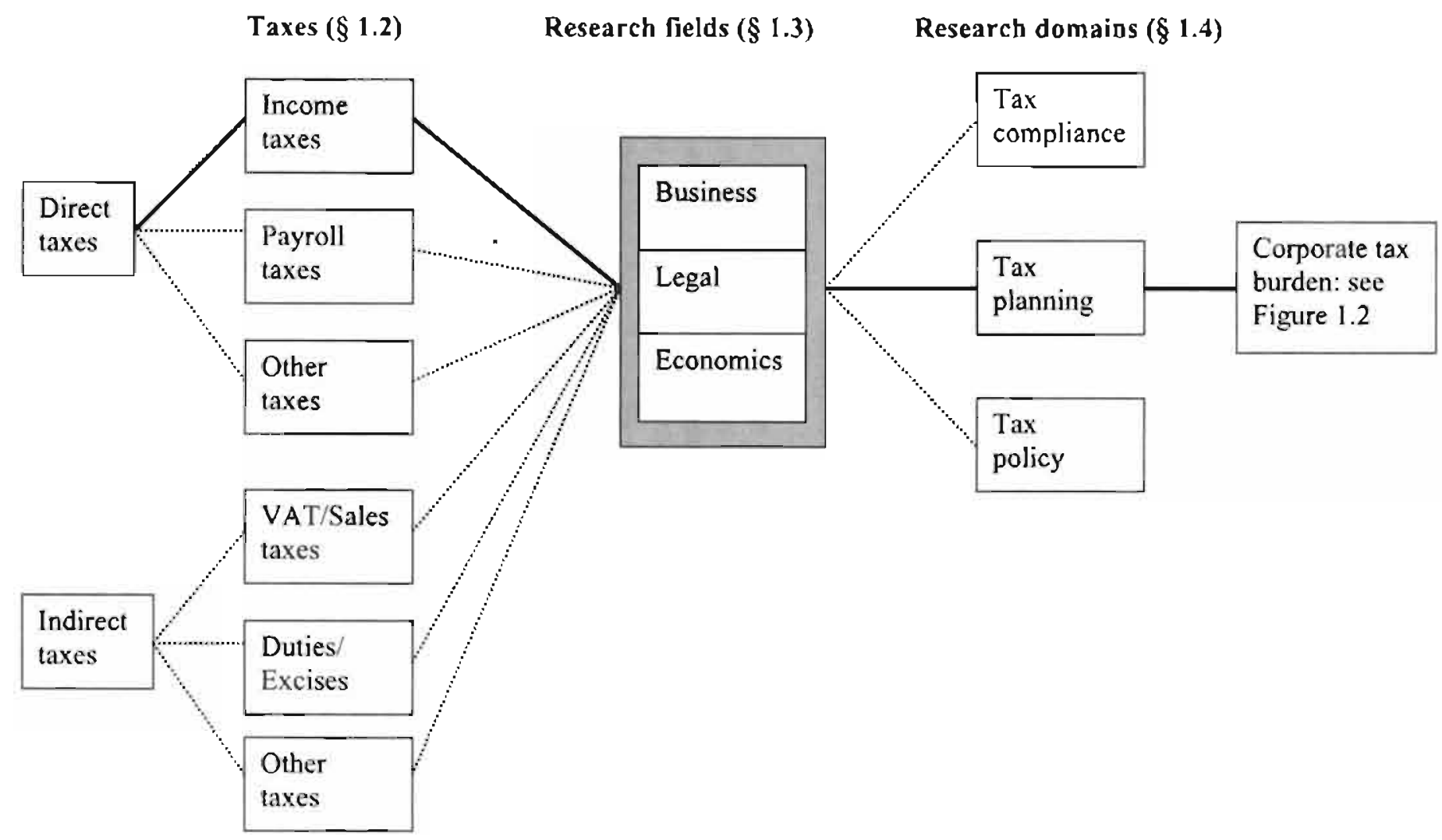




\subsection{Taxes}

\subsubsection{Overview}

The last few decades, total tax revenues within the EU have risen from an average of $33.5 \%$ of Gross Domestic Product in 1970 to $42.5 \%$ in 2000 (Cnossen 2001). To generate these revenues, lawmakers can design different forms of taxes (Musgrave 1969; Stiglitz 2000). The two broad classes of taxes are:

- Direct taxes on individuals and corporations;

- Indirect taxes on goods and services.

Direct taxes are directly borne by the tax subject (i.e., individuals or organizations) and are for the largest part levied on income (Stiglitz 2000). In contrast, indirect taxes are levied on tax objects (e.g., goods and services). Direct taxes include:

- Income taxes, both personal and corporate;

- Payroll taxes;

- Other taxes.

Below, a short description of each category is provided.

\subsubsection{Income taxes}

Income taxes are levied either on personal income or on corporate income. Personal income taxes are usually progressively levied on taxable income, whereas corporate income taxes are levied mainly proportional to taxable income. Common elements taken into account when assessing the level of (corporate) income taxes to be paid are:

- Tax base: what elements are to be included in taxable income;

- Tax incentives ${ }^{1}$ : deduction(s), special depreciation rules, and the like;

- Tax rates: which rate is applied to tax taxable income.

These three common elements vary with regard to their definitions and levels between countries, but also within countries, between companies. Not only do lawmakers purposely implement tax incentives for specific (groups of) taxpayers, individual and corporate taxpayers often do their best to structure

\footnotetext{
'Along with "tax incentives", also the comparable expressions "tax facilities" and "tax subsidies" are used in the literature. This dissertation will use "tax incentives" throughout, even when tax disincentives are meant.
} 
their activities in such a manner as to reduce their taxes payable. Such structuring of activities can be legal ("tax planning") or be illegal ("tax evasion"”) (Pearlman 1998).

\subsubsection{Payroll taxes}

Payroll taxes are levied directly on the payrolls of employers and have to be remitted to the taxing authorities by these employers. They are withholding taxes with regard to the personal income tax, that is: payroll taxes are deducted from the personal income taxes payable.

In cases where no personal income taxes are levied ${ }^{4}$, payroll taxes are sometimes not settled with income taxes and thus can be the only taxes levied on personal income. Like personal income taxes, payroll taxes tend to be progressively levied on payroll levels. Due to the nature of payroll taxes (paid by employers on behalf of employees and calculated using predetermined tables), there are limited opportunities to reduce payroll taxes payable by the tax subjects.

\subsubsection{Other direct taxes}

One of the most important other direct taxes (this depends on the country though) are social security contributions. Especially in continental European countries, social security contributions generate a large portion of governmental revenues. In some instances (e.g., the Netherlands), social security contributions are levied in an integrated manner, together with personal income taxes.

Social security contributions comprise a variety of elements, depending on country and socio-demographic properties of the tax subjects, but can include contributions for: disability benefits, unemployment benefits, widow(er) and orphan(s) benefits, and health benefits. Often social security benefits are partially paid by the employer and partially by the employee. This leaves fewer opportunities for the tax subject to try to reduce social securities contributions payable.

\footnotetext{
2This is also referred to as "tax avoidance" (Slemrod and Yitzhaki 2000).

3 "Tax evasion" includes "tax fraud", but also other forms of income underreporting (Engel and Hines 1999).

${ }^{4}$ For instance, when the taxpayer does not file a personal income tax return.
} 


\subsubsection{Indirect taxes}

Indirect taxes are characterized as taxes levied on tax objects, not on tax subjects (Stiglitz 2000). They are typically levied on a proportional basis. Within the European Union, value added taxes (VAT) are one of the most important indirect taxes. Indirect taxes include:

- Value added taxes (VAT)/Sales taxes;

- Duties on imported goods/excises on particular products, such as tobacco and alcohol;

- Other taxes, such as property taxes and transfer taxes.

\subsubsection{Value added taxes/sales taxes}

Most countries in the world have either a sales tax or a value added tax (VAT). A sales tax is levied on the final sale of a good or service to the consumer, whereas a VAT is levied on the value added to a good or service during the stages of the production process.

A sales tax is applied in Canada and the U.S. among others (with rates mainly varying between 0 and $10 \%$ ), whereas all European Union countries apply a VAT with a minimum rate of $15 \%$, generating on average about $17 \%$ of total tax revenues in the European Union (Van den Noord and Heady 2001).

\subsubsection{Duties/excises}

Duties and excises are levied on a variety of goods, ranging from duties on agricultural products $^{5}$ to excises on alcohol. The use of duties and excises is often motivated by specific reasons, such as limiting of competition and prevention of behavior deemed unhealthy.

Due to these different reasons for the institution of duties and excises and the different levels of taxation (ranging from a few percent to several hundred percent), this particular kind of indirect taxes offers a (very) complicated structure.

\subsubsection{Other indirect taxes}

Governments levy a large amount of other indirect taxes, such as property and transfer taxes, to name but just two. These taxes can be characterized by their specific nature; they are levied by specific governments (e.g., provincial governments) and/or are levied on specific objects (e.g., share capital).

\footnotetext{
"Within the EU, these duties are part of the "common agricultural policy (CAP)".
} 


\subsubsection{Taxes: conclusion}

The above discussion of direct and indirect taxes shows a large variety in purposes and structures of taxes. In general, two types of taxes can be distinguished: direct and indirect taxes. Direct taxes offer more opportunities for tax planning than indirect taxes, as the tax subject is also the actual taxpayer.

Within the category of direct taxes, corporate income taxes offer more possibilities for tax planning, as organizations (being a collection of capital investments) are more mobile than individuals (representing a combination of capital and labor), both within and between countries (Gorter and Parikh 2000). Corporate income taxes are the subject of this dissertation.

\subsection{Tax research fields focusing on corporate income taxes}

\subsubsection{Overview}

With regard to corporate income taxes, three broad research fields exist:

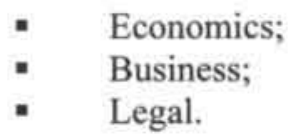

Below, a short description of each research field with respect to corporate income taxes is provided.

\subsubsection{Economics}

As with business research, economics research comprises a variety of research techniques and research questions. Stiglitz (2000) provides some examples of research questions typically addressed in economics research:

- On what economic elements is the corporation tax a tax on?

- Who bears the burden: stockholders, employees, or consumers?

- How does the corporation tax affect economic efficiency?

- How does the corporation tax affect financial decisions: debt, dividend, and mergers?

- Should there be a tax on corporations?

Earlier economics research (Atkinson and Stiglitz 1980; Musgrave 1969; Musgrave and Musgrave 1989) has shown that corporate income taxes affect economic decisions taken by organizations. More recent economics research has developed the notion of "tax competition" between governments (Hines 1999; 
Wilson 1999). Several empirical studies (e.g., De Mooij and Ederveen 2001, Van den Noord and Heady 2001) document the possible effects of such "tax competition". Cnossen (2001) provides a comprehensive economic perspective review of tax policy in the EU, including current developments, issues, and options.

\subsubsection{Business}

Business type research deals with the interaction between corporate income taxes and company activities in the broadest sense, mainly in the finance and accounting areas. Although tax research tends to be concentrated in specific areas, such as finance and accounting, a variety of research is encountered, including empirical, normative, and positive research (Shackelford and Shevlin 2001). Some major research areas are (Shackelford and Shevlin 2001):

- Coordination of tax and non-tax costs;

- Effects of taxes on asset prices;

- Taxation of multi-jurisdictional commerce.

These research areas show a close link between the economics and business research fields. Especially with regard to the topics in this dissertation (see below), there is a close link between the economics and business research fields. The business research field has input from the economics research field, whereas the economics research field receives input from business researchers (Shackelford and Shevlin 2001). This dissertation will mainly focus on the business research field in taxation research, with a further focus on the accounting area within this research field.

\subsubsection{Legal}

In contrast to business and economics research, legal research tends to focus on descriptive research, describing the corporate tax law(s) and its applications. As a result of this and of the nature of laws, legal research tends to be national in character. As far as international legal research is undertaken, it mainly deals with specific instances of cross-border transactions. Such research can be found in a variety of legal journals. Details on national tax laws themselves can be found in reference works, such as the European Tax Handbook (1998; published yearly) and International Tax Summaries (1998; published yearly). Detailed information on the Dutch corporate income tax can, for instance, be found in Verburg (2000). 


\subsection{Tax research domains in accounting}

\subsubsection{Overview}

The accounting area of the business research field relating to corporate income taxes research includes the following research domains (Shevlin 1999): Tax compliance; this domain focuses on the reporting aspect of taxes (e.g., filing tax returns) and is thus ex post. This is in contrast to tax planning, which deals ex ante with the structuring of (corporate) activities. The third domain, tax policy, is economics based and assesses the effects of tax behavior by tax subjects.

To investigate issues within these domains, researchers can use the following methodologies (Shevlin 1999): behavioral, using this methodology tax researchers can investigate the effects of tax rules on the behavior of tax subjects; experimental markets, using this methodology tax researchers can investigate responses of test subjects to specific settings in a laboratory environment; analytical, using this methodology tax researchers use theoretical frameworks to analyze relationships between tax and non-tax factors; archival empirical, using this methodology tax researchers use existing data sources (e.g., financial statements) to investigate relationships between tax and non-tax factors.

Below, a brief description of these research domains and relevant methodologies is provided.

\subsubsection{Tax compliance}

Research in this domain tries to answer the question what factors determine compliance with the tax code (Shevlin 1999). This domain mainly employs the following research methodologies: behavioral, analytical, and archival empirical. Roberts (1998) and Shields, Solomon, and Jackson (1995) all provide an overview of this research domain. In general the authors describe the relationship between (environmental) factors and the level of compliance of taxpayers.

\subsubsection{Tax planning}

Tax planning research tries to answer the question how individuals and companies respond to tax rules (Shevlin 1999). Most of the research in this domain uses the archival empirical research methodology. This dissertation is an example of research within this domain, specifically with regard to companies. More information is provided in section 1.5 and the empirical chapters. 


\subsubsection{Tax policy}

The overall goal of tax policy research is to assess the effects (and possibly effectiveness) of tax rule changes (Shevlin 1999). The main research methodologies employed in this area are archival empirical and to a lesser extent analytical research (e.g., Harris and Sansing 1998). Most tax policy research is ex post, thus evaluating tax rule changes. Zimmerman (1983) has had an influential role in encouraging this type of research. His research deals with the distribution of taxes within the corporate sector. Research in this area is closely related to the empirical studies in this dissertation.

\subsection{Dissertation topic}

Within the tax planning domain ${ }^{6}$, this dissertation investigates the tax burden issue, which includes both equity and efficiency issues (Callihan 1994). Equity of the tax system ${ }^{7}$ is often measured by comparing average effective tax rates across organizations, whereas efficiency of the tax system ${ }^{8}$ is often measured by comparing marginal effective tax rates of alternative investments.

Figure 1.2 provides more information on these different ways to measure tax burdens, starting with the distinction between average and marginal tax burdens. Using one of these burdens, several measurements can be used: macro backward, which uses macro-economic data, such as the ratio of corporate tax revenues to total government revenues; micro backward, which uses company data, usually financial statement information, and micro forward, using forward looking theoretical models, often based on the King-Fullerton approach. Nicodème (2001) provides more information on the different measurement methods.

As the goal of this dissertation is to examine (determinants of) explicit and implicit corporate tax burdens, average effective tax rates (ETRs) are used in the empirical chapters. ETRs are defined as (current) tax charge (derived from the company's financial statements) divided by pre-tax financial accounting income (Callihan 1994). Thus, ETRs measure the amount of (explicit) taxes payable by the company, as a fraction of pre-tax accounting income.

\footnotetext{
${ }^{6}$ The tax planning and tax policy domains are closely related. Thus, tax planning research has often tax policy implications and vice versa. Part of the empirical research in this dissertation could also be labelled as "tax policy" research.

${ }^{7}$ Equity of the tax system refers to the extent in which different taxpayers are taxed in the same manner. In contrast, efficiency of the tax system refers to the influence of taxes on economic decisions.

${ }^{8}$ Köthenbürger (2002) provides more information on the effects of tax competition, especially with regard to efficiency.
} 
Figure 1.2 Tax burden measurement

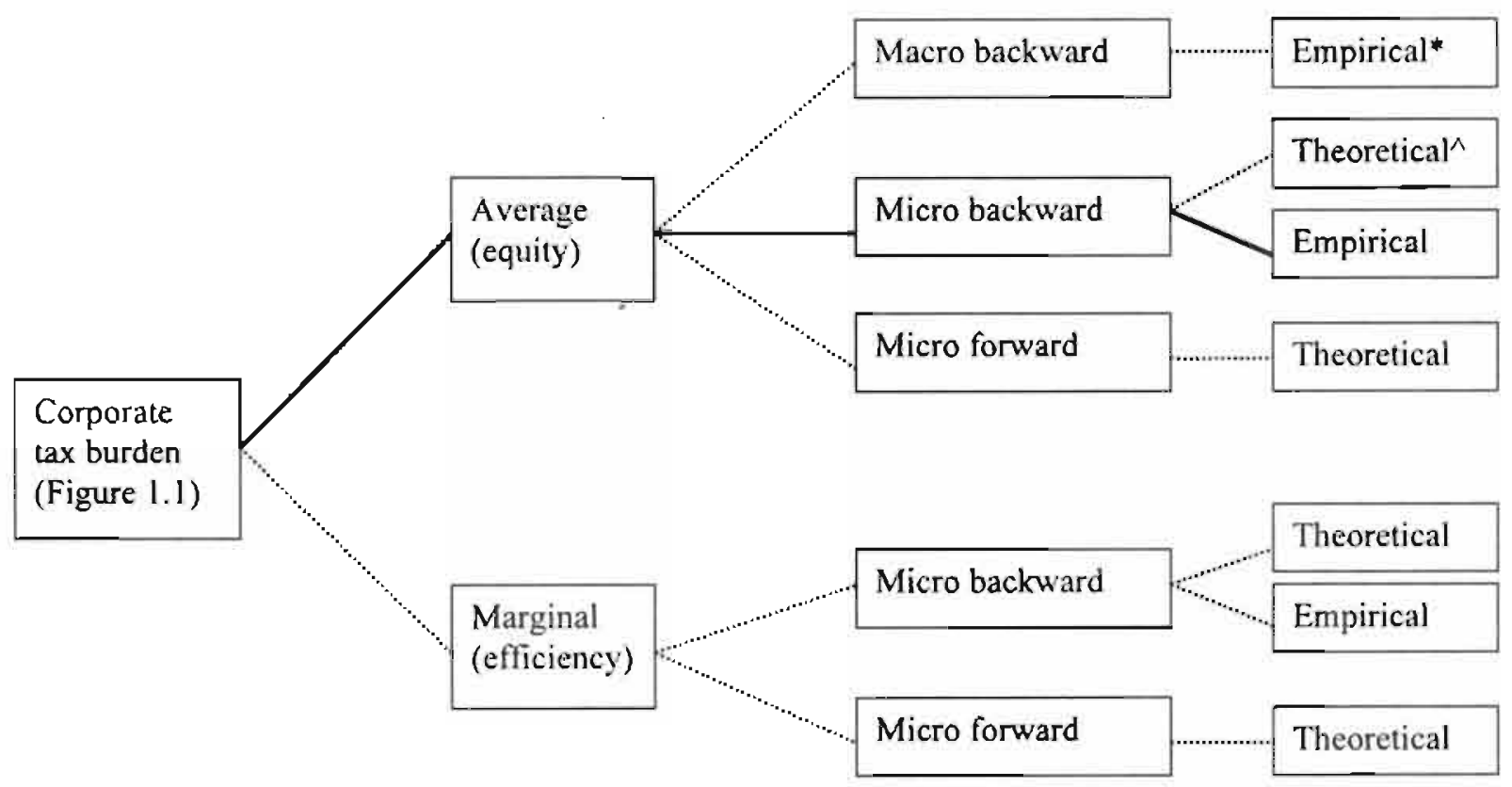

- Empirical: Calculated using empirical data (e.g., financial statement information)

"Theoretical: Calculated using statulory features of the comporate income tax

$=\quad$ Note: Figure is partially based on Nicodeme (2001). 


\subsection{Conclusion}

The purpose of this chapter is to provide a context for the three empirical chapters in this dissertation. An, admittedly brief, overview of corporate income tax research shows that the three empirical chapters can be set in the accounting area of business research (with a strong link to the economics research field) addressing the corporate income tax using an archival empirical methodology.

To measure (determinants of) implicit and explicit corporate tax burdens, the three following chapters use (derivatives of) average effective tax rates based on financial statement information. The first empirical chapter, chapter 2 , will investigate the explicit corporate tax burden on companies domiciled in the European Union. Chapter 3 contains a study on the determinants of explicit corporate tax burdens in the Netherlands. Following this, chapter 4 includes a study on the implicit corporate tax burdens in the European Union. The last chapter, chapter 5 , will provide a conclusion. 


\section{chapter 2}

\section{Evidence of the Effect of Domicile on Corporate Average Effective Tax Rates in the European Union}

\subsection{Introduction}

This chapter' uses consolidated financial statements to determine actual or effective tax rates (ETRs) for companies domiciled in European Union (EU) member states. There already exist differences in statutory corporate tax rates (STRs) $^{2}$ between EU countries. These differences are relatively easy to observe (see below). But EU countries also provide tax incentives to companies. To the extent that this happens, STRs do not provide a complete picture of (1) actual corporate tax burdens in EU countries, and (2) of differences in actual corporate tax burdens between companies domiciled in different EU countries. In this chapter an attempt is made to determine ETRs experienced by companies in EU countries using consolidated financial statement data for the recent $1990-1996$ period. These ETRs provide a picture of both differences in STRs and the provision of tax incentives between EU member states, i.e., of actual corporate tax burdens.

Such a picture is important because actual corporate tax burdens, which ETRs attempt to measure, are generally thought to be an important element in the "competitive" position of a country, e.g., in terms of location decisions of companies $^{3}$ or of founding rates of new companies. Also, actual corporate tax burdens are a constant item in discussions about tax competition between countries in general and between EU countries in particular. Knowledge about actual tax burdens is important for these discussions.

This chapter is the first empirical study to measure ETRs using financial statement information for (public) companies in all 15 current EU member

\footnotetext{
I This chapter is based on Buijink, Janssen, and Schols (2002).

${ }^{2}$ Statutory tax rates are the tax rates mentioned in the applicable corporate tax laws.

${ }^{3}$ For a recent empirical study, see Devereux and Griffith (1998).
} 
states. There are alternative approaches to measuring ETRs. This chapter uses financial statement-based ETRs to measure company-level worldwide corporate tax burdens. Another approach is to measure assumption-based ETRs.

ETRs determined using financial statements are company specific and require no simulation and underlying assumptions. They also can be used conveniently to make a distinction between permanent tax incentives and temporary tax incentives provided by the EU member state governments to companies domiciled in their jurisdiction.

Although differences between STRs and ETRs can also provide information on other factors, such as earnings management, such factors are not considered in the empirical design(s) in this dissertation.

The empirical findings are as follows. First, comparing EU member states on the basis of the difference between the STR and the ETR that takes into account permanent tax incentives, reveals considerable variation. That is, the use of (permanent) tax incentives differed quite substantially between EU member states (corporate domiciles) in the recent 1990-1996 period. Second, the range of the ETRs across EU member states is less centered than the statutory tax rate range. This means that the provision of permanent tax incentives does not have the effect of "equalizing" the existing differences in STRs between EU member states (corporate domiciles).

Additional analyses based on (1) using two alternative ETR measures (one less sensitive to financial accounting differences between EU member states and one taking into account temporary tax incentives as well), (2) restricting the analysis to those countries that already were a EU member state in 1990 , and (3) restricting the analysis to those EU member states that had already adapted national law to the seventh EU company law Directive, requiring consolidated financial statements from EU companies, by 1990, do not change these findings.

\subsection{Motivation, ETR measurement, financial accounting issues, and previous research}

\subsubsection{Motivation and ETR measurement}

STRs and tax bases (the amount of income on which entities are taxed) differ between EU Member States. The last few years these intra-EU differences have given rise to an increasingly active political discussion. The discussion is driven by the fact that taxes represent an actual cash outflow to companies and can be expected to affect (1) the attractiveness of company formation in EU countries, as well as (2) location decisions of EU (and non-EU) companies. These differences in corporate tax rates and tax bases create both an interest of the various national governments in corporate tax policy and an interest in tax 
policy on the part of companies in order to be able to decide on their preferred domicile.

Tax competition between countries in the area of corporate taxes can focus on (1) the STR, and additionally on (2) the provision of tax incentives in various forms ${ }^{4}$. To measure the corporate tax rate effectively experienced by a company domiciled in a given country, it is necessary to measure the tax rate in that country inclusive of the tax incentives effects, i.e., the effective tax rate, as opposed to statutory, tax rate. This chapter uses data for the companies in the current $15 \mathrm{EU}$ member states. The data used are for the years from 1990 to 1996. Of the current $15 \mathrm{EU}$ member states, 12 joined the EU before 1990. Austria, Finland and Sweden joined the EU in 1995. As a sensitivity check, an analysis of the data of the 12 pre-1990 EU members is provided.

The research question that this chapter attempts to answer is the following: what effect does the provision of tax incentives have on actual corporate tax burdens in EU member states? In particular: how do tax incentives affect the differences in actual corporate tax burden (ETR) within the EU when compared with the differences between EU member state STRs? Note, that larger, smaller, or similar differences in ETRs would all be consistent with tax incentives based tax competition between EU member states. That is, tax competition using tax incentives can have all three effects. This paper attempts to find out which effect is present. Examples of tax incentives that would affect ETRs in EU member states differentially are the following: the possibility of tax-loss carry backs and carry forwards, fiscal unity arrangements (compensating losses and profits between companies, in a group of companies), and participation exemption arrangements (relief for the income of (possibly foreign) subsidiaries already taxed).

Prior research has developed various ETR measures to measure corporate tax burdens taking into account tax incentives. Basically four (classes of) measures exist: (1) the effective marginal tax rate, (2) the effective average tax rate, (3) the financial accounting information based marginal effective tax rate, and (4) the financial accounting information based average effective tax rate. The four classes of measures are named this way to avoid confusion. The original terminology used in the literature is slightly different. The important distinction is that (3) and (4) are based, completely or in part, on actual financial accounting data, whereas (1) and (2) are based on an assumed "typical" investment project. Below, each measure is briefly discussed.

The effective marginal and the effective average tax rate are computed for a "typical" investment project earning no economic rents (for the effective marginal tax rate) and assumed positive rents (for the effective average tax rate). In both cases, the tax rate is the difference between the pre-tax return and the

\footnotetext{
${ }^{4}$ Alternatively, the statement here could be phrased referring to differences in the corporate tax base, i.e., taxable income.
} 
post-tax return as a proportion of the post-tax return in a given country (tax jurisdiction) for a "typical" project. Chennells and Griffith (1997, appendix A) provide a clear recent discussion of both measures.

In contrast, both the financial accounting information based marginal and average effective tax rate are calculated using actual company financial statements. Graham (1996, p. 189) conceptually defines the marginal effective tax rate in year $t$ for a company as "... the present value of [the current and] future tax obligation with earning US\$1 of (taxable) income in year $t$ ". He discusses eight possible effective marginal tax rate measures found in the literature. All are at least in part financial statements based. The average effective tax rate, finally, can be broadly defined as taxes paid by a company in a fiscal year divided by financial accounting income (Graham 1996, p. 195).

Callihan (1994, section 1), Chennells and Griffith (1997, appendix A), and Collins and Shackelford (1995, pp. 56-57) all discuss the relative advantages of the different classes of ETR measures.

In this chapter the effect of domicile on corporate tax incentives in EU member states is measured using the financial accounting information based average effective tax rate (average ETR), because the objective is to estimate the effect of tax incentives on the tax burden as it affects actual companies in the EU. As will become clear below, the average ETR purports to measure worldwide taxes payable for a given year as a fraction of worldwide pre-tax financial accounting income.

A comparison of worldwide ETRs for companies in EU member states with STRs in the countries in which these companies are domiciled is made. In the case of domestic companies, this comparison is non-controversial. In the case of multinational companies, also the STR of the country in which the parent company of the group is domiciled is used. This domicile STR is used because it is the government of the country in which the parent company is domiciled that makes the final decision on how worldwide income of the group of companies is taxed, i.e., that determines the worldwide tax burden. It must explicitly decide to exempt or not to exempt from domicile taxation, foreign source income already taxed abroad, but at a rate (STR or ETR) different from the domicile STR. If exemption is granted, the exemption is equivalent to the provision of a tax incentive (when the foreign STR or ETR is lower). Hence, both in this case and in the case where such an exemption is not granted, the parent company's domicile STR provides a relevant benchmark for the actual corporate tax burden in that domicile also for multinational companies.

In case of multinational companies, potential issues also include the (non-)repatriation of foreign subsidiary income and the in- or exclusion of subsidiary countries from bilateral tax treaties. All EU countries, except France, apply a worldwide tax base to their calculation of taxable income. The worldwide tax base principally covers worldwide income from all sources, 
including dividend and capital gains from foreign subsidiaries as an accrual basis is used to determine income.

\subsubsection{Within-EU accounting related ETR measurement issues}

A problem with the determination of company average ETRs in EU member states is that not all member states make the distinction between income in company financial statements and company taxable income (book-tax link). This is the case, to a varying degree, in the period considered in this paper, in: Austria, Belgium, Finland, France, Germany, Greece, Italy, Luxembourg, Portugal, and Sweden. The distinction does exist in the remaining five EU member states: Denmark, Ireland, The Netherlands, Spain, and the U.K. (Hoogendoorn 1996a).

However, the book-tax link is primarily an issue at the legal entity level. Therefore, in this paper consolidated financial statements ${ }^{5}$ are used. In consolidated financial statements a distinction is made in all EU member states between consolidated financial accounting income and consolidated taxable income $^{6}$.

The financial accounting background for the determination of the average ETR from financial statements is the following.

Two types of differences can exist between financial accounting income and taxable income. The first type are "temporary differences". These differences will exist as long as a certain item is included in the tax accounts but not in the financial accounts or the other way around. A sub-category of temporary differences are "semi-permanent differences". These differences will exist as long as a company will continue (1) its operations in general, or (2) operate the tax-affected assets, and will not reverse during those periods. Such temporary and semi-permanent differences lead to a deferral of (part of) taxes payable.

The second type of differences is "permanent differences". These differences will never cease to exist, i.e., will never reverse, not even when the company is discontinued. Permanent differences lead to elimination of (part of) taxes payable.

\footnotetext{
${ }^{5}$ The seventh EU company law Directive harmonized consolidated financial accounting in the $\mathrm{EU}$. In five of the current $15 \mathrm{EU}$ member states the seventh Directive was implemented after 1990: Finland in 1992, Ireland in 1992, Italy in 1991, Portugal in 1991, and Sweden in 1995 (see Nobes and Parker 2000, table 5.7). As a sensitivity check, an analysis for the 10 pre-1990 seventh Directive adopters is included.

${ }^{6}$ Documentation that underlies this remark for each of the "no-book-tax difference" EU countries is in Maukner (1998, p. 60) for Austria; in Jorissen and Maes (1996, p. 921) for Belgium; in Järvenpää (1996, p. 906) for Finland; in Hoareau (1998, p. 112) for France; in Haller (1998, p. 93) for Germany; in Caseley (1998, p. 479) for Greece; in Zambon (1998, p. 194) for Italy; in Clark (1994, p. 175) for Luxembourg; in Fernandes Ferreira (1998, p. 829) for Portugal; and in Heurlin and Pettersohn (1998, p. 1109) for Sweden.
} 
Within the EU, financial accounting for corporate taxes in consolidated financial statements proceeds as follows. The matching principle requires that the corporate tax expense item in the financial statements should relate to the financial accounting income reported in those statements, i.e., requires "interperiod tax allocation". When financial accounting income is not equal to taxable income, taxes actually paid will not be equal to the tax expense. In the financial statements this book-tax difference can be "accommodated" in two steps. First, permanent differences are always excluded from the tax expense item in the financial statements. Second, using "interperiod tax allocation", temporary differences are ex(in)cluded from (in) the tax expense item and this leads to a deferred tax liability (deferred tax asset) ${ }^{7}$. All EU countries use the matching principle for consolidated financial statements and thus, in principle, require recognition of the deferred tax liability/deferred tax asset.

The above shows that taxes payable for a company for a given year can be calculated from its consolidated financial statements by using the tax expense item, which is already exclusive of permanent differences (tax incentives), or by using an adjusted tax expense item, adjusted for either the appropriation to (from) the deferred tax liability (asset) or the change in the net deferred tax position ${ }^{8}$. This adjustment will reflect the temporary differences (tax incentives).

Hence, uniformly the tax expense in the consolidated financial statements in EU member states is exclusive of the permanent differences. In practice differences between EU member states in financial accounting for corporate taxes are possible, but they all concern temporary differences. Examples of a lack of uniformity in accounting for temporary differences between and withinEU member states are (Hoogendoorn 1996a, Table 3):

- A deferred tax asset is not recognized consistently because of the prudence principle or is netted against the deferred tax liability;

- There is no uniformity in "partial" or "full provision" for deferred taxes;

- There is no uniformity in the use of nominal or present value for deferred taxes;

- There is no uniformity in the approach for dealing with (expected) tax rate changes;

- There is no uniformity in deferred tax accounting for asset revaluation.

However, these complications are less of a problem in the consolidated financial statements that are used here, because EU consolidated financial statements are more standardized than EU parent-company financial statements.

\footnotetext{
${ }^{7}$ An alternative treatment is to ignore the book-tax difference. The advantage of this "flowthrough accounting" treatment is simplicity. The disadvantage of the method is that it does not adhere to the matching principle.

8 Actually, this is an estimate of that amount, see Plesko (2003). This is a further complication.
} 
Notwithstanding intra-EU financial accounting harmonization efforts, such as the fourth EU company law Directive that sets standards for the format and layout of EU financial statements, other differences in prescribed financial accounting methods still exist. But again, this problem is less important at the level of consolidated financial statements. This argument is a second reason for restricting the analysis to consolidated financial statements in EU member states.

The above underlies the three ETR measures used below. The first ETR measure relates tax expense (which excludes permanent differences) to before tax financial accounting income. In the second ETR measure, a company income measure is used that is less sensible to financial accounting differences between EU member states. In the third ETR measure, the tax expense is adjusted for temporary differences.

Also, 7-, 6-, or 5-year panels (see below for an explanation) of companies domiciled in the EU are used to calculate average ETRs for each company for the 7-, 6-, or 5-year periods. Note that this approach will further alleviate the effect of lack of uniformity between EU member states in financial accounting for temporary differences and of financial accounting, in general. This is caused by the reversal property of temporary differences and of accrual accounting methods, in general, on the ETR measures that are calculated.

\subsubsection{Average ETRs: prior cross-country research}

There exist a number of single-country financial accounting-based average ETR studies. Studies using EU member state data include Holland (1998) for the U.K., Janssen and Buijink (1998) for The Netherlands, and Ballas and Hevas (1999) for Greece. The most recent single-country papers using U.S. data are Gupta and Newberry (1997), and Plesko (2003). The last two papers provide references to earlier papers using U.S. data.

In this section, however, the focus is on the available comparative crosscountry studies. Comparative cross-country ETR results are rare, but include Chennells and Griffith (1997), and Collins and Shackelford (1995).

Collins and Shackelford (1995) calculate average ETRs (adjusted for temporary differences) for companies domiciled in Canada, Japan, the U.K., and the U.S. They use the Global Vantage database, for the period from 1982 to 1991 , resulting in a total of 30,037 firm-year observations. One central finding is that Japanese companies pay higher and Canadian companies pay lower percentages of financial accounting income in corporate tax (have higher (lower) ETRs) then do companies from the U.K. and the U.S.

\footnotetext{
${ }^{9}$ As Nobes and Parker (2000, p. 88) conclude: "The seventh Directive has achieved a significant degree of harmonization in group accounting (within the EU)."
} 
Chennells and Griffith (1997) also use the Global Vantage database to calculate average ETRs (not adjusted for temporary differences). They calculate these annually for the 1985-1994 period for 10 countries: Australia, Canada, France, Germany, Ireland, Italy, Japan, Spain, U.K., and the U.S. Chennells and Griffith (1997) find considerable differences between STR and mean ETR for Germany, Italy, and Spain with smaller differences for the other countries.

The results below are directly comparable to the Collins and Shackelford (1995) and Chennells and Griffith (1997) findings for a larger group of countries (compared to both studies) and larger company samples per country (compared to Chennells and Griffith (1997)).

\subsection{Methodology: measurement of the average ETR and sample}

\subsubsection{Average ETR}

The average ETR is measured in three different ways. Section 2.2.2 provided the financial accounting background. The ETRs are defined in the context of the Worldscope financial statement template and its terminology.

The first measure, ETR1, is income taxes (tax expense) divided by financial accounting pre-tax income before minority interest income, equity in earnings, and extraordinary income. Extraordinary income is presented net of tax in the Worldscope template, as is equity in earnings of non-consolidated subsidiaries. The inclusion of minority interest income (i.e., its non-elimination) is conventional in this literature. ETR1 "picks up" permanent tax incentives. Income taxes are worldwide income taxes. ETR1 is comparable to the accounting-based ETR measure used in Chennells and Griffith (1997). It is also used frequently in country-specific ETR research.

As explained earlier, ETR1 is potentially affected by inter-country differences in accrual financial accounting practices between EU countries. This result may occur even though this chapter uses consolidated financial statements and given European financial accounting harmonization. Therefore also, as a first sensitivity check, a second ETR measure less affected by differences in financial accounting practices between countries is calculated. An obvious candidate would be a measure with operating cash flow, i.e., operating income before non-cash expenses, as the denominator. However, cash flow statement data are not uniformly available on the Worldscope CD-ROM, especially in the earlier years of the period considered. Thus, the income statement item net sales as the denominator for the second ETR measure, ETR2 (again using income tax expense as the numerator) is used.

As a second sensitivity check, ETR3 is used. In ETR3, income tax expense adjusted for the net change in the deferred taxes (balance sheet item) is the numerator and financial accounting pretax income before minority interest 
(income), equity in earnings (from unconsolidated subsidiaries), and extraordinary income, is the denominator. ETR 3 "picks up" both permanent and temporary tax incentives. ETR 3 is directly comparable to the main ETR measure used in Collins and Shackelford (1995). ETR3 is also frequently used in previous country-specific research.

Table 1 gives the three ETR measures in terms of the Worldscope financial statement template terminology and item codes.

Table 1 Effective tax rate (ETR) measures

\begin{tabular}{|c|c|c|}
\hline $\begin{array}{l}\text { ETR } \\
\text { measures }\end{array}$ & 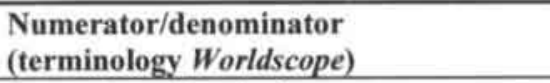 & Worldscope item codes \\
\hline ETRI & income taxes/pre-tax income & $01451 / 01401$ \\
\hline ETR2 & income taxes/net sales & $01451 / 01001$ \\
\hline ETR3 & $\begin{array}{l}\text { (income taxes - (deferred taxes } \text { - deferred }_{1} \\
\left.\text { taxes } s_{t-1}\right) \text { )/pre-tax income }\end{array}$ & $\left(01451-\left(03263_{t}-03263_{t-1}\right)\right) / 01401$ \\
\hline
\end{tabular}

\subsubsection{Sample}

The sample is a panel of all active (less inactive status companies), non-financial (less SIC codes 60, 61, 63 (financial companies) and less non-industrial financial statement template: i.e., "other" financial companies) companies whose consolidated financial statements (filter: only consolidated statements) are available on the Worldscope CD-ROM in all years from 1990 to 1996 (inclusive). Of course, only companies with domicile in one of the current 15 EU member states were selected. Note, that Worldscope's coverage is restricted to public companies.

For all three ETR measures, only those companies are retained for which all data-items necessary are available in all 7 years. A last filter removes for all three measures observations $><2$ standard deviations (S.D.) from the mean (outliers).

The year 1996 was the latest year available on this version (December 1998) of the Worldscope CD-ROM that is used and 1990 the first year (except for ETR3 for which 1991 is the first year for which results can be calculated).

Table 2 provides details about the initial sample selection. The initial panel (first five filters) consists of 2,958 companies in EU member states with data for seven years, i.e., 20,706 firm-years in all. The use of the last two filters leads to a panel of 2,118 companies (14,826 firm-years) for which ETR1 can be determined, of 2,083 companies (14,581 firm-years) for ETR2, and of 1,393 companies (8,358 firm-years) for ETR3 (6-year panel). The adjustment for deferred taxes in ETR3 (1) makes 1991 the first year for which results can be given, but also (2) leads to considerable loss of company year panels due to loss of observations in the last year 1996. Therefore also a second ETR3 panel is 
used (ETR3 (5-year panel)) for the period 1991-1995, consisting, after the last two filters, of 1,628 companies ( 8,140 firm-years).

Table 2 Sample selection criteria (firm-years between brackets)

\begin{tabular}{|c|c|c|c|}
\hline Step & Description & Not available & Available \\
\hline I & $\begin{array}{l}\text { Companies domiciled in EU member states with } \\
\text { consolidated financial statements available in } \\
\text { Worldscope database }\end{array}$ & & 5,180 \\
\hline 2 & Less: companies with inactive status & 1,093 & 4,087 \\
\hline 3 & Less: SIC codes $60,61 \& 63$ (financial companies) & 606 & 3,481 \\
\hline 4 & $\begin{array}{l}\text { Less: companies with a non-industrial template (other } \\
\text { financial companies) }\end{array}$ & 523 & 2,958 \\
\hline & Available companies in initial panel & 2,958 & $(20,706)$ \\
\hline & Available companies in panel for ETR $1^{a}$ & 2,118 & $(14,826)$ \\
\hline & Available companies in panel for ETR2 ${ }^{\mathrm{b}}$ & 2,083 & $(14,581)$ \\
\hline & Available firm-years for ETR $3^{\circ}$ (6-year ${ }^{d}$ panel) & 1,393 & $(8,358)$ \\
\hline & Available firm-years for ETR $3^{\mathrm{C}}$ (5-year ${ }^{\mathrm{d}}$ panel) & 1,628 & $(8,140)$ \\
\hline
\end{tabular}

"ETRI = income taxes/pre-tax income.

${ }^{\mathrm{b}} \mathrm{ETR} 2=$ income taxes/net sales.

${ }^{\mathrm{C}}$ ETR3 $=\left(\right.$ income taxes $-\left(\right.$ deferred taxes - deferred taxes t-1 $\left.\left._{1}\right)\right) /$ pre-tax income.

${ }^{\mathrm{d}}$ As explained in the text, for ETR3, 6- and 5-year panels are used.

Table 3 provides the number of companies in the sub-panel for each of the EU member states and the corresponding number of firm-years, for each of the ETR measures. As can be seen, for Luxembourg and Greece the number of firmyears available is relatively small for ETR1 and ETR2. This is also the case for those two countries and for Austria and Sweden for ETR3 (6-year panel and 5year panels), but not for Greece for the ETR3 for the 5-year panel ${ }^{10}$.

\footnotetext{
${ }^{10}$ Note, that different panel length (6-year vs. 5-year) leads to considerable changes in the number of observations available in the countries in Table 3.
} 
Table 3 Number of companies in panel and for effective tax rate (ETR) calculations for European Union member states (1990-1996, 19911995/1996 for ETR3) (firm-years between brackets)

\begin{tabular}{|c|c|c|c|c|c|c|c|c|}
\hline EU member states & ETR1 $^{2}$ & & ETR2 & & $\begin{array}{l}\text { ETR3 }^{c} \\
\text { (6-year }\end{array}$ & panel) & $\begin{array}{l}\text { ETR3 }^{c} \\
\text { (5-year }\end{array}$ & panel) \\
\hline Austria & 39 & (273) & 37 & (259) & 1 & (6) & 1 & (5) \\
\hline Belgium & 50 & $(350)$ & 52 & (364) & 21 & $(126)$ & 35 & (175) \\
\hline Denmark & 101 & (707) & 96 & $(672)$ & 76 & (456) & 88 & $(440)$ \\
\hline Finland & 69 & (483) & 75 & (525) & 29 & (174) & 36 & $(180)$ \\
\hline France & 289 & $(2,023)$ & 276 & $(1,932)$ & 149 & (894) & 178 & (890) \\
\hline Germany & 319 & $(2,233)$ & 317 & $(2,219)$ & 41 & (246) & 57 & (285) \\
\hline Greece & 5 & (35) & 5 & (35) & 4 & (24) & 23 & (115) \\
\hline Ireland & 40 & $(280)$ & 35 & (245) & 41 & (246) & 42 & $(210)$ \\
\hline Italy & 27 & (189) & 25 & (175) & 16 & (96) & 47 & (235) \\
\hline Luxembourg & 5 & (35) & 5 & (35) & 1 & (6) & 2 & (10) \\
\hline The Netherlands & 123 & $(861)$ & 123 & (861) & 112 & $(672)$ & 119 & (595) \\
\hline Portugal & 32 & (224) & 32 & (224) & 32 & (192) & 36 & (180) \\
\hline Spain & 84 & (588) & 79 & (553) & 61 & (366) & 78 & (390) \\
\hline Sweden & 103 & (721) & 101 & (707) & 1 & (6) & 1 & (6) \\
\hline United Kingdom & 832 & $(5,824)$ & 825 & $(5,775)$ & 808 & $(4,848)$ & 885 & $(4,425)$ \\
\hline $\begin{array}{l}\text { Total number of } \\
\text { companies } \\
\text { (firm-years) }\end{array}$ & 2,118 & $(14,826)$ & 2,083 & $(14,581)$ & 1,393 & $(8,358)$ & 1,628 & $(8,140)$ \\
\hline
\end{tabular}

${ }^{\text {"ETRI }}=$ income taxes/pre-tax income

${ }^{\mathrm{b}} \mathrm{ETR} 2=$ income taxes/net sales

${ }^{c}$ ETR3 $=\left(\right.$ income taxes $-\left(\right.$ deferred taxes - deferred taxes st-1 $\left.\left._{1}\right)\right) /$ pre-tax income

\subsection{Results}

\subsubsection{Statutory tax rates (STRs) in EU member states}

Various sources are used to determine the STRs in the EU member states between 1990 and 1996. Table 4 provides an overview of the annual STRs in the EU member states for a number of years. A number of member states, notably France, Germany, and Ireland have multiple corporate tax rates.

It is not immediately obvious how to determine the average STR in each EU member state for the 1990-1996 period. The average STR for each country is determined in two ways.

In Table 4 the unweighted average STR for each country is the simple average, assuming a $50 \%$ pay-out ratio for countries (years) with a split-rate system. For the weighted average STR in Table 4, the weight for each year is the total pre-tax income for all companies in the ETR1 sample. Additionally, in countries (years) with a split-rate system the total relative amount of pre-tax income distributed is also used as weight. For Ireland the number of companies 
in the sample in qualifying industries and their total pre-tax income is used as weight.

The STRs in Table 4 were calculated disregarding differential capital gains tax rates and differential tax rates for "low" profits that exist(ed) in a number of countries. Previous research has often used unweighted STRs, disregarding differences in STRs across time and companies. Table 4 reports both unweighted and weighted STRs (taking into account differences in STRs and relative profit levels), but subsequent analyses are only based on weighted STRs. As can be seen in Table 4, the average STRs (both unweighted and weighted) are in the $30-50 \%$ region. The top three STRs are in Italy, Germany, and Belgium, whereas the lowest rates are found in Greece, Sweden, and Ireland. The correlation between unweighted and weighted STRs is high: Pearson's correlation coefficient is 0.97 . Below, the weighted STR is used with additional results for the unweighted STR. 


\begin{tabular}{|c|c|c|c|c|c|c|c|c|c|}
\hline Country & 1990 & 1991 & 1992 & 1993 & 1994 & 1995 & 1996 & Uw.avg. & W. avg. \\
\hline Austria & 39.00 & 39.00 & 39.00 & 39.00 & 34.00 & 34.00 & 34.00 & 36.86 & 36.02 \\
\hline Belgium & 43.00 & 39.00 & 39.00 & 39.00 & 40.17 & 40.17 & 40.17 & 40.07 & 40.28 \\
\hline Denmark & 40.00 & 38.00 & 38.00 & 36.00 & 34.00 & 34.00 & 34.00 & 36.29 & 35.78 \\
\hline Finland & 40.20 & 40.20 & 40.20 & 34.10 & 28.00 & 28.00 & 28.00 & 34.10 & 34.02 \\
\hline France & $\begin{array}{l}\operatorname{RE}^{d}: 37 \\
\operatorname{DP}^{\mathrm{c}}: 42\end{array}$ & $\begin{array}{l}\text { RE: } 34.0 \\
\text { DP: } 42.0\end{array}$ & 33.33 & 33.33 & 33.33 & 36.67 & 36.67 & $35.83^{i}$ & 34.70 \\
\hline Germany & $\begin{array}{l}\text { RE: } 56.5 \\
\text { DP: } 44.3\end{array}$ & $\begin{array}{l}\text { RE: } 56.5 \\
\text { DP: } 44.3\end{array}$ & $\begin{array}{l}\text { RE: } 58.1 \\
\text { DP: } 45.5\end{array}$ & $\begin{array}{l}\mathrm{RE}: 56.5 \\
\mathrm{DP}: 44.1\end{array}$ & $\begin{array}{l}\text { RE: } 54.9 \\
\text { DP: } 42.6\end{array}$ & $\begin{array}{l}\text { RE: } 54.9 \\
\text { DP: } 42.6\end{array}$ & $\begin{array}{l}\text { RE: } 56 \\
\text { DP: } 42\end{array}$ & $49.90^{f}$ & 50.05 \\
\hline Greece & $\begin{array}{r}\text { RE: } 46 \\
\text { DP: } 0\end{array}$ & $\begin{array}{l}\text { RE: } 46.0 \\
\text { DP: } 0.00\end{array}$ & $\begin{array}{r}-\mathrm{RE}: 46.0 \\
\mathrm{DP}: 0.00\end{array}$ & 35.00 & 35.00 & 35.00 & 35.00 & $29.86^{\prime}$ & 32.53 \\
\hline Ireland & $\begin{array}{r}43.00 \\
Q^{2}: 10\end{array}$ & $\begin{array}{l}43.00 \\
Q: 10\end{array}$ & $\begin{array}{r}40.00 \\
Q: 10\end{array}$ & $\begin{array}{l}40.00 \\
Q: 10\end{array}$ & $\begin{array}{l}40.00 \\
Q: 10\end{array}$ & $\begin{array}{l}38.00 \\
Q: 10\end{array}$ & $\begin{array}{l}38.00 \\
Q: 10\end{array}$ & $28.69^{h}$ & $21.94^{\mathrm{b}}$ \\
\hline Italy & 46.00 & 47.80 & 47.80 & 52.20 & 52.20 & 53.20 & 53.20 & 50.34 & 50.48 \\
\hline Luxembourg & 39.40 & 39.40 & 39.40 & 39.40 & 39.40 & 39.40 & 39.40 & 39.40 & 39.40 \\
\hline The Netherlands & 35.00 & 35.00 & 35.00 & 35.00 & 35.00 & 35.00 & 35.00 & 35.00 & 35.00 \\
\hline Portugal & 39.60 & 39.60 & 39.60 & 39.60 & 39.60 & 38.80 & 38.80 & 39.37 & 39.29 \\
\hline Spain & 35.30 & 35.30 & 35.30 & 35.30 & 35.30 & 35.30 & 35.30 & 35.30 & 35.30 \\
\hline Sweden & 30.00 & 30.00 & 30.00 & 29.00 & 28.00 & 28.00 & 28.00 & 29.00 & 28.54 \\
\hline U.K. & 34.00 & 34.00 & 33.00 & 33.00 & 33.00 & 33.00 & 33.00 & 33.29 & 33.35 \\
\hline
\end{tabular}

"The sources used for this Table are: Cnossen (1996), Coopers \& Lybrand (1998), Easson (1993), Messeree (1993), OECD (1991), Teixeira (1997), and Tirard (1994); ${ }^{b}$ Unw.avg. = unweighted average of the statutory tax rates for the 1990-1996 period: ${ }^{\mathrm{C}}$ W.avg. = weighted average, taking into account relative profits per year and the distinction between the RE and DP tax rates where applicable, for the 1990-1996 period; ${ }^{\circ}$ RE gives corporate tax on retained earnings; ${ }^{\circ}$ DP gives corporate tax on distributed profits; ${ }^{f}$ assuming a proportion of retained earnings/distributed profits of $50 / 50:{ }^{B} \mathrm{Q}$ gives corporate tax on qualifying companies: i.e. manufacturing companies, manufacturing services, international financial services, trading operations in Shannon airport, repair and maintenance of aircraft, ships and computer equipment, film production, engineering services for projects outside Ireland, and organic production; ${ }^{h}$ companies allocated to either tax regime based on SIC industry code. 


\subsubsection{Average ETRs in the EU member states}

The total panel of 2,118 companies for ETR1 has been subdivided in 15 subpanels, one for each EU member state. For each country panel of companies, ETR1 is calculated for each company as the average ETR1 for the period 19901996. The results are shown in Table 5.

Table 5 Statutory tax rates (STR) and mean (standard deviation) and median (interquartile range) effective tax rates ((filtered) ETR1) for European Union member states (1990-1996) (\%)

\begin{tabular}{|lccccc|}
\hline Country & STR $^{\mathbf{a}}$ & $\begin{array}{c}\text { Mean } \\
\text { ETR1 }^{\text {b }}\end{array}$ & $\begin{array}{l}\text { Standard } \\
\text { deviation }\end{array}$ & $\begin{array}{l}\text { Median } \\
\text { ETR1 }^{\text {b }}\end{array}$ & $\begin{array}{l}\text { Interquartile } \\
\text { range }\end{array}$ \\
\hline Austria & 36.02 & 19.72 & 16.55 & 17.67 & 27.62 \\
Belgium & 40.28 & 21.64 & 23.35 & 20.99 & 24.63 \\
Denmark & 35.78 & 23.29 & 91.18 & 29.40 & 18.38 \\
Finland & 34.02 & 25.28 & 40.46 & 29.82 & 23.26 \\
France & 34.70 & 28.45 & 40.84 & 32.82 & 17.38 \\
Germany & 50.05 & 33.61 & 31.51 & 38.53 & 29.25 \\
Greece & 32.53 & 19.79 & 5.97 & 20.85 & 11.60 \\
Ireland & 21.94 & 13.78 & 9.75 & 13.86 & 19.24 \\
Italy & 50.48 & 30.66 & 16.06 & 35.32 & 23.58 \\
Luxembourg & 39.40 & 35.81 & 20.32 & 34.09 & 30.50 \\
The Netherlands & 35.00 & 26.84 & 13.59 & 31.80 & 17.88 \\
Portugal & 39.29 & 16.89 & 17.23 & 17.19 & 29.38 \\
Spain & 35.30 & 22.90 & 13.44 & 24.11 & 17.10 \\
Sweden & 28.54 & 27.01 & 20.93 & 27.47 & 21.24 \\
U.K. & 33.35 & 25.98 & 15.91 & 29.00 & 16.14 \\
\hline
\end{tabular}

"Statutory tax rates (weighted STRs) are taken from last column of Table 4.

${ }^{\mathrm{b}} \mathrm{ETR} 1=$ income taxes/pre-tax income.

As explained earlier, the ETR1 results in Table 5 are on a filtered panel basis. The panel for each country was filtered by removing outlying observations with an ETR1, which out-centered the average ETR1 for the panel by more than two standard deviations. Table 5 shows that the mean and median ETR1 are quite close. The focus is on median ETR1. Focusing on the median results for the filtered data provides additional assurance that outlying observations, e.g., as in the case of Denmark, do not affect the results. Table 5 shows that median ETRs in EU member states are highest in Germany, Italy, and Luxembourg, and lowest in Austria, Portugal, and Ireland.

EU member states can also be ranked on the basis of the size of differences between STR (weighted average) and median ETR1, to show the effects of tax incentives. Table 6 provides the ranking. 
Table 6 European Union member states ranked by the difference between statutory tax rate and effective tax rate ((filtered) median ETR1)(19901996)

\begin{tabular}{|clc|}
\hline \multicolumn{1}{|l}{ Rank } & Country & STR $^{\text {a }}$ - median ETR1 \\
\hline 1 & Sweden & 1.07 \\
\hline 2 & France & 1.88 \\
3 & The Netherlands & 3.20 \\
4 & Finland & 4.20 \\
5 & United Kingdom & 4.35 \\
6 & Luxembourg & 5.31 \\
7 & Denmark & 6.38 \\
8 & Ireland & 8.08 \\
- & AVERAGE EU & 9.58 \\
9 & Spain & 11.19 \\
10 & Germany & 11.52 \\
11 & Greece & 11.68 \\
12 & Italy & 15.16 \\
13 & Austria & 18.35 \\
14 & Belgium & 19.29 \\
15 & Portugal & 22.10 \\
\hline
\end{tabular}

"Statutory tax rates (weighted STR) are taken from last column of Table 4.

${ }^{b}$ ETRI is taken from before last column of Table 5 .

Table 6 shows that, on average, in the EU the median ETRI is almost 10 percentage points below the STR. There are, however, considerable differences between the different EU member states. Whereas Sweden and France have a median ETR1 less then 2 percentage-points below their STR, Austria, Belgium, and Portugal have a median ETR1 of around 20 percentage points below their STR.

However (in accordance with the research question in section 2.2.1), the provision of tax incentives does not lead to ETRs being more equal between EU member states than the STRs.

Here, and below, the coefficient of variation $(\mathrm{CV}=$ standard deviation/mean) is used as a simple metric to measure the relative variability in STRs and ETRs between EU member states. The CV of the weighted STR (in Table 4) is below the coefficient of variation of the filtered median ETR1 (in Table 5): $19.1 \%$ versus $26.6 \%$. Hence, corporate effective tax burdens (ETR1) do not differ less between countries than do corporate STRs. The provision of tax incentives does not make corporate tax burdens in the EU more equal compared to STRs. 


\subsection{Additional analyses}

\subsubsection{Alternative ETRs}

A problem with the ETR1 scores for different EU member states is the potentially confounding influence of differences in financial reporting practices between the member states. As explained earlier, ETR2 was also calculated with a denominator less susceptible to financial accounting practice differences. Net sales is used as denominator, which "eliminates" all between EU country accounting related differences. The result, the (filtered) median ETR2 for the 1990-1996 period, is shown in Table 7.

Table 7 Effective tax rates (filtered median ETR2 and filtered median ETR3) for European Union member states 1990-1996 (1991-1995 or 1991-1996 for ETR3) (\%)

\begin{tabular}{|lccc|}
\hline Country & Median ETR2 $^{{ }^{\mathbf{a}}}$ & Median ETR3 $^{{ }^{b}}$ & Median ETR3 $^{\mathbf{c}}$ \\
\hline Austria & 0.83 & 13.64 & 13.64 \\
Belgium & 1.19 & 23.56 & 26.83 \\
Denmark & 0.95 & 23.54 & 23.86 \\
Finland & 1.02 & 27.49 & 26.68 \\
France & 1.43 & 31.72 & 32.28 \\
Germany & 1.08 & 36.21 & 38.14 \\
Greece & 1.66 & 23.18 & 23.67 \\
Ireland & 1.10 & 12.58 & 12.85 \\
Italy & 2.56 & 37.35 & 34.77 \\
Luxembourg & 3.69 & 68.35 & 40.24 \\
The Netherlands & 1.25 & 31.37 & 31.36 \\
Portugal & 0.84 & 16.97 & 18.30 \\
Spain & 1.23 & 23.45 & 22.29 \\
Sweden & 0.92 & 18.68 & 18.68 \\
U.K. & 1.76 & 28.28 & 27.53 \\
\hline
\end{tabular}

"ETR2 $=$ income taxes/net sales

${ }^{b}$ ETR3 $^{-}=\left(\right.$income taxes $-\left(\right.$deferred taxes $_{t}-$ deferred taxes $\left.\left._{-1-1}\right)\right) /$ pre-tax income, 6-year panel

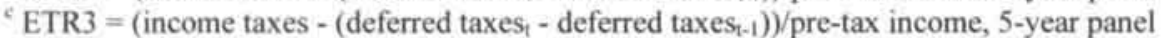

The CV for median ETR2 in Table 7 is also higher than the CV for STR (Table 5): $51.8 \%$ vs. $19.1 \%$. However, the Pearson's correlation coefficient between median ETR1 (Table 5) and median ETR 2 (Table 7) is only 0.44, indicating that ETR1 and ETR2 do not rank EU member states consistently. Hence, part of the ETR1 differences between countries may be attributable to financial accounting differences. On the other hand, as explained earlier, ETR2 as defined here is not the ideal "financial accounting differences free" measure.

As a further sensitivity check, ETR3 was calculated, which is ETR1 adjusted for the change in the (net) deferred tax liability. The results are also in Table 7. They show the filtered median ETR3 scores for each EU member state, 
both for the 6- and the 5-year panel in which 1996 is not used, i.e., for the 1991 1995 period. As explained earlier, in the 5-year panel, loss of observations for the ETR3 is less severe. Overall median ETR3 and ETR1 (Table 5) scores are similar. ETR3 is lower most of the time, as expected, indicating a slow reversal of temporary differences. Note, that the 6-year panel ETR3 score for Luxembourg ( 1 observation, see Table 3 ) is extreme. The focus is therefore on the 5-year panel results therefore. Median ETR1 and ETR3 (5-year panel) also rank member states similarly, underscoring the results given earlier: Pearson's correlation coefficient is 0.88 . Again, the CV of median ETR3 (5-year panel) is higher then that for STR (Table 5): $30.7 \%$ versus $19.1 \%$.

\subsubsection{STRs}

Inspection of the CVs of unweighted average STRs in Table 4 and of median ETR1, ETR2, and ETR3 (5-year panel) already reported does not change the conclusions of the previous section.

\subsubsection{Different sets of countries}

Additionally, CVs for weighted STR and median ETR1 (both in Table 5) were calculated for (1) the group of current EU member states that were already in the EU before 1990 (15 current member states except Austria, Finland, and Sweden), and (2) the group of current EU members that had already adapted national law to the seventh EU company law Directive on consolidated financial statements in 1990 (fifteen current member states except Ireland, Italy, Finland, Portugal, and Sweden). For the group of pre-1990 EU members, CVs for STR and ETR1 are 19.7 and $27.3 \%$. For the group of pre-1990 seventh Directive adopters the CVs are 13.0 and $22.9 \%$. Again, in both cases, tax incentives appear to widen the differences in effective corporate tax burdens in the EU compared to the STRs.

\subsection{Conclusion}

This chapter is the first study that attempts to measure actual worldwide corporate tax burdens for companies domiciled in all EU member states based on financial statement information. The main results are that (1) the provision of tax incentives, both those of a permanent and of a temporary nature, differs substantially between EU member states, and (2) these tax incentives do not have the effect of equalizing actual corporate tax burdens in the EU, i.e., actual corporate tax burdens differ more between EU member states (company domiciles) than do the statutory tax rates (STRs). 
A limitation of this research is that differences in (1) accounting for corporate taxation, and in (2) financial accounting in general between EU member states are problematic. To address both problems, this chapter (1) used only consolidated financial statements, (2) calculated ETRs for several years, and (3) provided additional results based on alternative ETR measures.

A further limitation of this paper is that it focused on public companies in EU member states. Results for ETRs of non-public companies would potentially provide a more balanced picture of corporate tax burdens in the EU.

An interesting question is, what factors cause differences in ETRs between EU countries. Collins and Shackelford (1995) begin to explore the effect on ETRs of foreign activities of companies. However, foreign activity is but one of several company characteristics that affect ETRs in a given domicile. Other characteristics that can have this effect, for local and multinational companies alike, are size (e.g., there could be economies of scale in tax planning investments), capital intensity (through the tax treatment of depreciation), R\&D intensity (through the tax treatment of R\&D expenditures), leverage (through the tax treatment of interest), ownership status (more concentrated ownership may lead to more aggressive tax planning), etc. Another interesting question is whether ETR levels persist over time. In other words, are companies able to retain tax incentives over time? Although interesting, such questions are outside the scope of this dissertation and not investigated. 


\section{chapter 3}

\section{Determinants of the Variability of Corporate Effective Tax Rates (ETRs): Evidence for The Netherlands}

\subsection{Introduction and motivation}

Recent empirical research has documented significant differences in financial statement based estimates of tax costs of corporate domicile between EU member states (Buijink, Janssen, and Schols (1999, 2000a) and de Mooij and Gorter (2001)) and OECD member states (Buijink, Janssen, and Schols (2000b), Chennells and Griffith (1997), and Collins and Shackelford (1995, 2001)). This research also documents that in the countries surveyed effective tax rates (ETRs) vary, but are systematically below the statutory tax rates (STRs) (see also chapter 2 of this dissertation). The ETR is a measure of a company's tax burden generally calculated as (current or total) income tax expense divided by before-tax financial accounting income (Callihan 1994). The differences between STRs and ETRs reflect differences in tax incentives provided by the governments of these countries to companies.

This chapter focuses on the variability of the tax costs of corporate domicile within one country, i.e., on the question of what explains the variation of ETRs around the country average or median.

Examination of the determinants of the variability of corporate ETRs within one jurisdiction will lead to an understanding of the pattern and effects of tax incentives provided to companies within that jurisdiction. This provides the main motivation for this chapter, with the focus being on the Netherlands.

This chapter builds on earlier research investigating determinants of ETRs. This research regarding determinants of the cross-section of ETRs has not been matched by Dutch research. A study by the Dutch tax authorities (Belastingdienst 1997) does investigate cross-sectional differences between the company financial accounting tax expense and actual taxes paid. Although interesting, the study is descriptive, focusing on individual not consolidated financial statements and only 
providing aggregated results. It provides no information on the differences observed in relation to company characteristics. This chapter is the first study to provide information on the determinants of ETRs for Dutch companies.

This chapter uses a company level panel firm-years sample for six years from 1994 to 1999.

The findings suggest the following. First, ETRs are (at most) a few percentage points below the statutory tax rates, indicating the (small) magnitude of tax incentives that are provided to Dutch companies (regarding this point, see also chapter 2).

Second, statistical results indicate a number of significant relationships between company characteristics and ETRs. However, the magnitude of these relationships is small. In general, the levying of corporate income taxes in the Netherlands appears to be fairly neutral. That is, ETR levels appear, to a large extent, to be not significantly affected by company characteristics in the Netherlands.

The remainder of this chapter is organized as follows. Section 3.2 describes previous research on the variability of ETRs and the hypotheses development. Section 3.3 explains financial accounting for income taxes in The Netherlands. Section 3.4 discusses research methods: the source of the data sample, variable definitions, and model specification. Results are given in section 3.5. The chapter ends with a summary and concluding remarks in section 3.6.

\subsection{Background, previous research, and hypotheses}

\subsubsection{Background}

Research on the determinants of the cross-section of company ETR data begins with Stickney and McGee (1982). Callihan (1994) is a useful survey of ETR research up to 1994. As explained in Callihan there are two varieties of empirical ETR research: research looking at marginal ETRs and research into average ETRs. The marginal ETR for a specific investment is the rate of tax paid on an additional unit of income from a specific investment project. Marginal ETRs should be used to investigate the effect of taxation on investment decisions. Marginal ETRs can also be used at the level of a company, but of course a company is a collection of investment projects, which makes the uses of marginal ETRs at that level problematic. For a discussion, see Callihan (1994, section 3.1.3; see also chapters 1 and 2 of this dissertation).

Average ETRs are better suited to express the overall tax burden on the company (Callihan 1994). They express the rate of tax paid on company income. This chapter, because of its focus on the determinants of the variability of the tax burden across companies, looks at average ETRs. This review of previous research therefore focuses on average ETRs. 
To provide structure for the discussion of existing company level average ETR research, this chapter uses an approach developed by Wilkie (1988), that identifies categories of determinants of the variability of average ETRs across companies.

ETR is the ratio of tax expense ( $\mathrm{T}$ ) over pre-tax financial accounting income (I) of a company. Thus,

$$
\mathrm{ETR}=\frac{\mathrm{T}}{\mathrm{I}}
$$

And tax expense $\mathrm{T}$ is taxable income $(\mathrm{TI})$ times the statutory tax $\operatorname{rate}(\mathrm{t}): \mathrm{T}=\mathrm{TI}^{*} \mathrm{t}$. Therefore,

$$
\operatorname{ETR}=\frac{(\mathrm{TI} * \mathrm{t})}{\mathrm{I}}
$$

Wilkie (1988) then introduces the notion of tax preferences ${ }^{\prime}$ (TP), which is the difference between financial accounting pre-tax income and taxable income: TP $=\mathrm{I}-\mathrm{TI}$, hence $\mathrm{TI}=\mathrm{I}-\mathrm{TP}$. Tax preferences include the temporary and permanent differences between financial accounting pre-tax income and taxable income. Substituting TI in (2) leads to ETR $=[(\mathrm{I}-\mathrm{TP}) / \mathrm{I}] * \mathrm{t}$, which simplifies to,

$$
\mathrm{ETR}=\frac{(1-\mathrm{TP})}{\mathrm{I}} * \mathrm{t}
$$

for a company, and the subscript $\mathrm{i}$ has been omitted.

Equation (3) shows how company ETRs are influenced by the variability across companies in tax preferences (TP), financial accounting pre-tax income (I), and tax rate changes $(t)$.

This last equation implicitly underlies previous research on the determinants of the cross-section of ETRs.

\subsubsection{Previous research}

\subsubsection{Size.}

In previous research, tax incentives have been modeled as a function of company size and of a company's operating, financing, and investment decisions.

Zimmerman (1983) suggested that larger companies would, because of their larger political visibility, have fewer tax incentives available to them than smaller

\footnotetext{
'Tax preferences are the collective tax incentives provided by the governments of the different countries the company is located in. Apart from this section, this chapter uses "tax incentives" throughout.
} 
companies. An interesting alternative rationale for such an effect is that suggested by Scholes and Wolfson (1992). They expect that large mature companies may find it difficult to aggressively pursue tax planning, because that may interfere with other tax impacted contracts.

The counter argument is that larger companies have, or can buy, more tax expertise, or have more political clout to obtain advantageous tax incentives. Zimmerman (1983) did indeed find, as he expected, a positive effect of company size on ETRs. However, his findings were disputed by Porcano (1986) who found a negative effect on ETRs of company size. Wilkie and Limberg (1990) subsequently reconciled these different findings by pointing out relevant differences in the research designs of Zimmerman (1983) and Porcano (1986). Among them were differences in ETR definitions.

In a contemporaneous paper, Omer, Molloy, and Ziebart (1991) make a similar methodological contribution. In a later paper, Shevlin and Porter (1992), after taking into account Wilkie and Limberg's (1990) remarks, still report the finding of progressive company income taxes, albeit in a univariate framework. Holland (1998) finds a positive size effect for the UK for a number of years in his twenty-six year period. However, he also finds a few years with negative size effects.

\subsubsection{Other determinants and control variables.}

Neither Zimmerman (1983), nor Porcano (1986) studied the variation in ETRs in a multivariate framework. However, there are more company characteristics potentially influencing tax incentives to companies. This point was made early on by Stickney and McGee (1982), and more recently by Gupta and Newberry (1997). Capital structure (i.e., leverage) can inversely affect ETRs (i.e., lower ETRs) because interest expenses are tax deductible, whereas dividends are not. Also, asset mix may impact ETRs inversely because tax incentives are often granted for capital investment: investment credits or favorable tax depreciation schedules. Stickney and McGee (1982), using US data, have looked at both leverage and capital intensity in a multivariate framework and found the effects expected. Interestingly, in their multivariate analysis they found no effect for company size. Gupta and Newberry (1997) used several asset mix variables and leverage in their multiple regression model explaining variability of ETRs. They also found the effects expected. Again, their results did not show a company size effect in a multivariate framework. Stickney and McGee (1982) also included the extent of foreign operations of a company as an explanatory variable. The extent of foreign operations influences ETRs, for instance in the US context, through tax credits extended for foreign profits earned in more lightly taxed environments. They indeed found an inverse effect (more foreign operations, lower ETRs). Gupta and Newberry did not include this variable. Stickney and McGee (1982) also investigated the impact of industry on ETRs. They found that certain US industries (natural resources) are treated more favorably tax-wise. 
Because the focus in ETR research is on the cross-sectional distribution of tax incentives granted to companies, equation (3) suggests the use of company profitability as a control variable. Gupta and Newberry (1997) include return on total assets (ROA) in their model and document the expected positive (higher ROA, higher ETR) effect.

Other control variables suggested in the literature are a financial accounting loss (NOL) and a negative tax expense (NTE). NOLs proxy for negative taxable income. Negative taxable income creates a tax shield lowering ETRs in different years. NOLs will directly confound the company size effect on ETRs, when larger companies (i.e., more diversified companies) profit less from this type of tax shield. Furthermore, NOLs will also indirectly confound the company size effect, as suggested by Wang (1991). Also, NOL and NTE can lead to negative ETRs, which are difficult to interpret. The occurrence of both NOL and NTE will lead to positive ETRs. In this chapter firm-year observations with NOLs and/or NTEs are dropped from the sample, in line with (part of) the literature. Sensitivity analyses for a sample including NOL/NTE observations is provided in section 3.5.3.2.

Equation (3) also suggests that tax rate changes will affect ETRs. Gupta and Newberry (1997) look at the effect of tax reform in the US in 1986 (the Tax Reform Act of 1986, TRA86) in the area of company income tax, by estimating their ETR model for a panel of companies pre-TRA86 and post-TRA86. Shevlin and Porter (1992) also investigate the effect of TRA86 on ETRs, and furthermore complement the measurement of ETRs by decomposing the observed changes into an income effect, a tax rate effect, and a tax rule effect.

So far the determinants of the cross-section of ETRs used in previous research carry over to the Dutch context. A particular feature of the Dutch financial reporting system (not present in the US) is that both public ${ }^{2}$ (listed) and private (non-listed) companies above a certain threshold have to file their financial statements. This creates the opportunity to investigate a fuller set of determinants that have been suggested in the literature. Cloyd, Pratt, and Stock (1996) and Mills and Newberry (2001) suggest that public companies have larger book-tax income differences because public companies have more $\operatorname{costs}^{3}$ from reporting low book income compared to tax income. In other words, for public companies it is more important to report high book income, and managers of these companies are less likely to consider tax decisions directly (Cloyd, Pratt, and Stock 1996, p. 34). Public companies are thus expected to have lower ETRs.

\footnotetext{
${ }^{2}$ Public companies are defined in this chapter as those Dutch companies that are listed on a stock exchange.

${ }^{3}$ Such costs include lower management compensation, lower market value of the company, and debt covenant violations (Mills and Newberry 2001).
} 


\subsubsection{Development of hypotheses}

The discussion in the previous section motivates the following hypotheses. The hypotheses are stated with direction where possible. Precise variable definitions (e.g., in terms of REACH A mnemonics) will be given in sections 3.4.3.1 and 3.4.3.2. Additional Dutch context motivation is given where appropriate.

Previous research relating company size to ETRs usually found conflicting results. Therefore, the hypothesis is stated without sign. In the Netherlands, the possibility of defining a fiscal unity (parent/subsidiaries) within a company is more likely to be used in larger companies since they will have more subsidiaries. Also favorable tax rulings in the Netherlands may be more likely for larger companies as well as certain investment incentives. On the other hand, certain investment incentives in the Netherlands may accrue disproportionally more to smaller companies.

\section{H1 Company ETRs are related to company size.}

Previous research, notably Gupta and Newberry (1997) and Stickney and McGee (1982), has found an inverse relationship between capital intensity and ETRs, due to tax incentives associated with investments in fixed assets, notably accelerated depreciation provisions. The Netherlands allows companies to depreciate fixed assets on a liberal basis. Also, there are tax incentives for investments in fixed assets. Therefore, an inverse relationship can be expected.

\section{H2 Company ETRs are inversely related to capital intensity (fixed assets/total assets).}

The Netherlands has a system of participation exemptions for subsidiary income which specifically also applies to foreign subsidiaries. In effect the Netherlands has a territorial corporate income tax system (see, te Spenke 1995, section 4.5.1). Depending on the weighted average of foreign income to net income and the relevant foreign statutory tax rates, company ETRs will be positively or negatively related to the extent of foreign operations.

\section{H3 Company ETRs are related to the extent of foreign operations (foreign sales/total sales).}

Wilkie (1988) argues that tax incentives are associated with company characteristics, such as capital intensity, but also with income. Gupta and Newberry (1997) expand Wilkie's argument and argue for the inclusion of a profitability measure. They find support for this association. Most Dutch tax incentives do not seem to be related to profitability, therefore a sign for this hypothesis is not stated. 
Interest costs are tax deductible, whereas dividend is not. Thus companies with more leverage (and high interest expenses) are expected to have lower ETRs.

H5 Company ETRs are inversely related to leverage.

As explained earlier, public companies have more incentives than private companies to report higher (nonconforming) book income compared to taxable income. Thus public companies are expected to have lower ETRs.

\section{H6 Company ETRs are lower for public companies.}

For hypotheses 1, 3, and 4 no expectation of direction is stated. Since there was no important corporate income tax rate or tax rule change in the Netherlands in the 1994-1999 period, there is no need to formulate a tax rate/tax rule effect hypothesis.

\subsubsection{Discussion}

One problematic aspect of average ETR research is the issue of the definition of the average ETR. As mentioned above, empirical outcomes may depend on specific definitions of the ETR. Wilkie and Limberg (1993) go so far as suggesting an alternative tax incentives variable, tax subsidy on equity (TSE). This measure presumes corporate income taxes are related to stockholder's equity. Corporate income taxes are, however, based on income. This chapter will therefore not use TSE. The definition of the ETR variables will be defined in section 3.4.3.2.

Some authors have used an ETR variable based on pre-tax operating cash flow as denominator, notably Zimmerman (1983). The idea behind this is to correct for the effect of financial accounting method choices that may be interrelated to the explanatory variables of the ETR. This chapter also uses a cash flow based ETR measure in this paper. 


\subsection{ETRs, the financial accounting treatment of company income tax in The Netherlands, and the relevant statutory company tax rate}

\subsubsection{Financial accounting treatment of company income tax in the Netherlands}

The only sources of data readily available to researchers outside the company (apart from the tax authorities) for the calculation of company ETRs are published financial statements. Financial statements are used in this chapter to calculate company ETRs in the Netherlands. The use of financial statements for the calculation of ETRs requires consideration of the financial accounting treatment of company income taxes. Dutch financial accounting practices are affected by financial accounting legislation and by financial accounting standard setting by the Council on Annual Reporting ("Raad voor de Jaarverslaggeving", RJ). While Dutch companies are obliged to follow the existing legal financial accounting requirements, RJ financial accounting standards are not obligatory in the data period examined (van der Tas 1998) ${ }^{4}$. There are both legal requirements and RJ standards for the financial accounting treatment of company income taxes 5 .

Differences between financial accounting income and taxable income for a given year for companies arise in countries where there is independence in the determination of these two types of company income. Such independence exists in the Netherlands. Companies in the Netherlands are required to use interperiod tax allocation to deal with temporary differences between financial accounting income and taxable income. Of course, both permanent and temporary differences are possible in this context. When the effect of permanent differences on the tax rate implied by the income tax expense is "considerable", the reasons for such permanent differences have to be explained in the financial statements notes section.

Temporary differences require the use of deferred taxes, which leads to deferred tax assets, and more typically to deferred tax liabilities. Separate identification of the current deferred tax expense in the income statement is not required. Hence, the current deferred tax expense can only be approximated by calculating the annual change in the deferred tax liability. Comprehensive allocation is required, and while using the present value of tax liabilities is allowed, almost always the nominal value is shown by Dutch companies. Finally, use of the liability method is required.

A recent discussion in English of financial reporting regulation for income tax accounting in the Netherlands is Hoogendoorn (1996b). The most recent survey of company practice in this area is van der Gaar and van der Tas (1991, in Dutch) for the year 1989. A recent exhaustive and clear treatment of income tax accounting

\footnotetext{
${ }^{4}$ See, Zeff, van der Wel, and Camfferman (1992) for an insightful history of Dutch financial reporting regulation and for a description of the current situation.

${ }^{5}$ Dutch financial reporting law and RJ standards are available in English in Guidelines (1999).
} 
in the Netherlands is Kampschoër (1997, in Dutch; a more recent version is in Kampschoër 2001), who gives exact references to legal requirements and relevant RJ standards. The survey research of van der Gaar and van der Tas (1991) shows that Dutch companies generally stay close to the RJ standards, on a voluntary basis.

\subsubsection{Relevant statutory corporate income tax rate}

The analyses are based on data for the years 1994 to 1999, as there are no important Dutch corporate tax law changes during this period. Specifically, during this period the corporate income tax rates in the Netherlands were as follows: 40 per cent of the first Hfl. 100,000/€ 45,378 (prior to July 1994: Hfl. $250.000 / € 113,445$ ) and 35 per cent of the excess above that amount (te Spenke, 1995, p. 112) ${ }^{6}$. For all practical purposes, the statutory tax rate (STR) for the larger Dutch companies in the sample (see below) was around 35 percent in the 1994 - 1999 period.

\subsection{Research methods: data, sample, model, and variables}

\subsubsection{The REACH data file}

The sample in this chapter consists of companies whose financial statements were taken from the 2001 (release 63) CD-ROM REACH A data file for the period 19941999 , the most recent period available on that CD-ROM, but also a period during which there were no important tax rule changes. The $R E A C H$ A data file is produced from financial statements of companies filing financial statements in the Netherlands with the local Chamber of Commerce registry.

The company producing the $R E A C H \mathrm{~A}$ data file takes financial statements and transfers information from these to its own "model" format of financial statements of which there are two types: an abbreviated model format and a complete model format. The existence of two formats is a consequence of the fact that Dutch financial reporting regulation has several disclosure regimes. The $R E A C H$ A complete model format corresponds to the disclosure regime for the largest companies. All items in the REACH A complete model format are identified with a name and number identification. These identifications are used below to define the variables used in this paper.

\subsubsection{Sample selection}

This chapter only uses data for companies for which financial statements are available in the REACH detailed model format. Five groups of observations in the

\footnotetext{
${ }^{6}$ In 1996 the $40 \%$ tax rate was lowered to $37 \%$ and in 1997 to $36 \%$. For 1998 and $199935 \%$ is the uniform corporate income tax rate in the Netherlands.
} 
sample were deleted. Deleted were (i) non-trade and industry companies, (ii) companies with a special status, (iii) dependent companies ${ }^{7}$, (iv) companies not having the public limited ("NV") or private limited ("BV") legal form, (v) investment funds, and (vi) NOL/NTE firm-years.

The first group was deleted as these companies have a differing financial reporting format. Special status companies were deleted as these do not report regular financial statements. Dependent companies are deleted as they are taxed at a (possibly differing) foreign tax rate. Non-incorporated companies as well as investment funds are not subject to the regular corporate tax regulations and were therefore excluded from the sample. Based on the discussion in section 3.2.2.2 NOL/NTE observations are deleted.

Finally, to create the 1994-1999 sample only those companies were retained for which sufficient data was available to calculate the ETR measures (see below for the variable definitions). This resulted in a final sample of 1,592 companies. A summary of the way the final sample was arrived at is given in Table 1.

The subsequent analyses are based on those companies that report data for all relevant variables. Of the 1,592 companies, 1,041/967 companies (respectively 4,155 and 3,833 firm-years) report data for all variables used in the ETR1/ETR2 definition.

Table 1 Sample selection criteria

\begin{tabular}{|llrc|}
\hline Step & Description & Not available & Available \\
\hline 1 & $\begin{array}{l}\text { Trade and industry companies on } \mathrm{REACH} \text { (detailed } \\
\text { statements) }\end{array}$ & & 4,943 \\
2 & And not companies with a special status & 305 & 4,638 \\
3 & And not dependent companies & 2,701 & 1,937 \\
4 & And not non-incorporated companies & 50 & 1,887 \\
5 & And not investment funds & 49 & 1,838 \\
6 & And not NOLNTE observations & 246 & 1,592 \\
\hline
\end{tabular}

3.4.3 Multivariate model and variable definitions

\subsubsection{Model.}

The following model is used to test the hypotheses. This model will be estimated for ETR 1 and ETR 2.

$$
\begin{aligned}
& \text { ETR }_{\mathrm{ti}}=\alpha_{\mathrm{ti}}+\beta_{1} \text { FSIZE }_{\mathrm{ii}}+\beta_{2} \text { CAPINT }_{\mathrm{it}}+\beta_{3} \text { FOREIGN }_{\mathrm{ti}}+\beta_{4} \text { ROA }_{\mathrm{ti}}+\beta_{5} \text { LEV }_{\mathrm{ti}}+ \\
& \beta_{6} \text { PUBLIC }_{\mathrm{ti}}+\varepsilon_{\mathrm{ti}}
\end{aligned}
$$

$t$ is a firm-year between 1994 and 1999

$\mathrm{i}$ is an individual company from the firm-years sample

\footnotetext{
${ }^{7}$ This effectively also eliminates non-consolidated financial statements.
} 
The following control variables relating to operating losses and negative tax expenses are used in the sensitivity analyses (see section 3.5 .3 .2 ):

$\mathrm{NOL}_{\mathrm{ti}} ; \mathrm{NTE}_{\mathrm{ti}} ; \mathrm{NOL}^{*} \mathrm{NTE}_{\mathrm{ti}} ; \mathrm{NOL}^{*} \mathrm{FSIZE}_{\mathrm{i}} ; \mathrm{NTE}^{*} \mathrm{FSIZE}_{\mathrm{ti}}$

The variable codings represent the following variables. ETR is effective tax rate 1 or 2 (see below for explanation of ETR 1 and ETR 2). FSIZE is company size, defined as natural logarithm of total assets (in REACH A mnemonics: natural logarithm of item 1230). Capital intensity (CAPINT) is defined as tangible fixed assets divided by total assets (in REACH A mnemonics: item 1090 divided by item 1230). FOREIGN $^{8}$ proxies for the extent of international activities and is defined as net foreign sales over net sales (in REACH A mnemonics: item 1233 divided by item 1003). Return on assets (ROA) is defined as net earnings divided by total assets (in REACH A mnemonics: item 1055 divided by item 1230). LEVERAGE is the company's leverage, defined as long term liabilities divided by total assets (in REACH A mnemonics: item 1189 divided by item 1230). PUBLIC is the dummy variable indicating a public company.

Financial accounting loss (NOL) is defined as a dummy variable being 1 when the company experiences a financial accounting loss for the current year (in REACH A mnemonics: if item $1055<0$ then $\mathrm{NOL}=1$; otherwise $\mathrm{NOL}=0$ ). NTE stands for negative tax expense, a dummy variable being 1 when the company reports a negative tax expense (in REACH A mnemonics: if item $1056<0$ then $\mathrm{NTE}=1$; otherwise NTE $=0$ ). NOL*NTE is a dummy variable being 1 when the company experiences both a NOL as well as a NTE (in REACH A mnemonics: if item $1055<0$ and item $1056<0$ then NOL*NTE $=1$; otherwise NOL*NTE $=0$ ). NOL*FSIZE is an interaction variable for financial accounting loss and company size with NTE*FSIZE being an interaction variable for negative tax expense and company size. Finally, $\alpha$ is the intercept with $\varepsilon$ being the error term.

\subsubsection{Calculation of ETRs.}

As Dutch financial reporting requirements only require disclosure of deferred tax liabilities, but not deferred tax assets, only deferred tax liabilities in the ETR definitions are used. Furthermore, as the tax expense accrues to the entire income in the Dutch context the current tax expense is used as well as full financial accounting income before interest and taxes in the ETR measures.

To control for possible differences in financial reporting between companies, this chapter also uses an alternative ETR definition, based on cash flow. The ETR definitions are (also see chapter 2 where a different approach was used):

\footnotetext{
${ }^{8}$ This variable shows a relatively large number of cases with missing data. This is likely related to companies with no or immaterial amounts of foreign sales not reporting this item. Such missing data are recoded "0". All subsequent analyses are based on this recoded variable. Appendix 1 provides information showing the effects of this recoding.
} 


$$
\mathrm{ETR} 1=\frac{\left(1056-\left(1178_{\mathrm{t}}-1178_{\mathrm{t}-1}\right)\right)}{1034}
$$

being: the ratio of (tax expense - (deferred tax provision $_{t}$ - deferred tax provision $\left._{1-1}\right)$ ) over earnings before interest and taxes.

$$
\operatorname{ETR} 2=\frac{\left(1056-\left(1178_{t}-1178_{t-1}\right)\right)}{(1254-(1034-1055))}
$$

being: the ratio of (tax expense - (deferred tax provision $_{t}$ - deferred tax provision $\left._{t-1}\right)$ ) over (cash flow - (earnings before interest and taxes - earnings before interest) in terms of REACH A item identification items.

Both ETR measures include interest expenses in the denominator because leverage is used as explanatory variable in subsequent analyses.

\subsubsection{Estimation Procedure.}

To investigate model (4), stated in section 3.4.3.1, an OLS regression model is estimated to assess the relationship between determinants and ETR.

The analyses in this chapter are based on pooled firm-year (FY) observations for the period 1994-1999. Results from such statistical analyses may be affected by serial correlation in the data. To facilitate comparison between the pooled sample and the annual samples, the appendices include annual descriptive and annual OLS regression results.

Additionally, to investigate possible nonlinear relationships between determinants and ETRs as well as to control for the non-normal distribution of financial accounting data, a rank regression model $(\mathrm{RR})^{9}$ is used to estimate the multivariate model. Below the OLS and RR results are reported. To test for nonlinear relationships the parametric variables are classified in deciles in the RR (Fama and French 1996).

As ETR ratios can easily result in extreme values, ETR 1 and ETR 2 are filtered at two standard deviations from the mean (see, for instance, Anderson, Banker, and Janakiraman 2003). This reduced firm-year observations involving ETR 1 by $1.40 \%$ and firm-year observations involving ETR 2 by $0.50 \%$. Final ETR 1/ETR 2 samples numbered 4,097/3,814 firm-years (down from 4,155/3,833 firm-years for the unfiltered sample).

\footnotetext{
${ }^{9}$ More information on this particular type of linear models is available in Greene (2002) and Neter, Kutner, Nachtsheim, and Wasserman (1996). Callihan and White (1999), and Lang and Lundholm (1996) use a comparable technique called monotonic regression. More information on this method is available in Conover (1980), and Conover and Iman (1981).
} 


\subsection{Results}

\subsubsection{Descriptive and univariate results}

Table 2 provides descriptive statistics for both ETR measures of the pooled firmyear observations for the 1994-1999 period. Table 2 shows that the mean and median ETRs are somewhat below the statutory tax rate of $35 \%$. However, standard deviation and interquartile range show considerable variation between companies in the sample. The cash flow based ETR2 measure descriptive statistics tend to be lower for central tendency measures with a larger dispersion around these measures. Appendix 2 provides descriptive statistics for the pooled sample (also for the unfiltered sample as this shows the effect of filtering).

Table 2 Descriptive statistics for ETR 1 and 2 (1994-1999)

\begin{tabular}{|lcc|}
\hline Statistic & ETR 1 & ETR 2 \\
\hline Mean & 0.321 & 0.279 \\
Standard deviation & 0.271 & 0.369 \\
Median & 0.341 & 0.270 \\
Interquartile range & 0.149 & 0.265 \\
Firm-years & 4,097 & 3,814 \\
\hline
\end{tabular}

For variable definitions see sections 3.4.3.1 and 3.4.3.2.

Tables 3 and 4 provide descriptive univariate tests of the hypotheses. Table 4 does that separately for the PUBLIC dummy variable. Table 3 shows ETR 1 and ETR 2 means, medians, and standard deviation for quartiles of company size, capital intensity, relative importance of foreign sales, ROA, and leverage. Quartiles are in increasing order for the explanatory variables. The numbers in bold report the number of firm-year 'observations. Table 3 does not document consistent relationships across both ETR measures between company characteristics and ETR levels. As far as individual relationships are discernable these appear to be limited to one or two quartiles (e.g., ETR2 and CAPINT), but not the complete distribution. 
Table 3 Results for univariate descriptive statistics: mean and median ETRs for quartiles of explanatory variables (1994-1999)

\begin{tabular}{|c|c|c|c|c|c|c|c|c|c|c|}
\hline \multirow{4}{*}{$\begin{array}{l}\text { Variable } \\
\text { Expected } \\
\text { sign }\end{array}$} & \multicolumn{2}{|c|}{ FSIZE } & \multicolumn{2}{|c|}{ CAPINT } & \multicolumn{2}{|c|}{ FOREIGN $^{10}$} & \multicolumn{2}{|c|}{ ROA } & \multicolumn{2}{|c|}{ LEV } \\
\hline & $?$ & $?$ & - & - & $?$ & $?$ & $?$ & $?$ & - & - \\
\hline & ETR & ETR & ETR & ETR & ETR & ETR & ETR & ETR & ETR & ETR \\
\hline & 1 & 2 & 1 & 2 & $I$ & 2 & 1 & 2 & 1 & 2 \\
\hline $1^{\text {sf }}$ quartile & 1,024 & 953 & 1,024 & 953 & 280 & 278 & 1,024 & 953 & 1,024 & 953 \\
\hline & 333 & 0.271 & .323 & 0.360 & 0.324 & 0.292 & 0.325 & 0.168 & 0.329 & 0.306 \\
\hline & & 0.270 & & & 0.341 & 0.269 & & & & 0.308 \\
\hline & 3 & 0.304 & & & & & & & 0.243 & 0.316 \\
\hline rtile & & & & & 280 & 278 & 1,024 & 953 & 1,024 & 953 \\
\hline & 0.326 & 0.275 & 6 & 0.30 & 338 & 0.279 & 0.310 & 0.270 & 0.299 & 0.255 \\
\hline & 351 & 0.281 & 8 & 0.3 & & 0.274 & & 34 & 0.331 & 0.265 \\
\hline & 0.278 & 0.371 & 0.254 & 0.361 & 0.251 & 0.360 & 0.234 & 0.398 & 0.253 & 0.393 \\
\hline Irtile & 1,024 & 954 & 1,024 & 954 & 280 & 278 & 1,024 & 954 & 1,024 & 954 \\
\hline & & & & & 0.322 & 0.3 & & 0.3 & 0.330 & 0.284 \\
\hline & 0.346 & 0.281 & & 0.27 & 0.332 & 0.30 & 0.340 & 0.297 & 0.339 & 0.252 \\
\hline & 0.270 & 0.421 & 0.257 & 0.286 & 0.211 & 0.340 & 0.153 & 0.253 & 0.272 & 0.335 \\
\hline 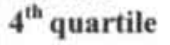 & 1,025 & & & 954 & 280 & & 1,025 & & 1,025 & 954 \\
\hline & & 0.272 & & 0.19 & 0.311 & 0.312 & 0.330 & 0.370 & 0.324 & 0.265 \\
\hline & & & 0.340 & 0.1 & 0.310 & 0.280 & 0.350 & 0.369 & 0.344 & 0.234 \\
\hline std. dev. & 0.257 & 0.350 & 0.303 & 0.377 & 0.276 & 0.300 & 0.108 & 0.163 & 0.335 & 0.454 \\
\hline
\end{tabular}

For variable definitions see sections 3.4 .3 .1 and 3.4.3.2.

For the dummy variable PUBLIC, ETR1 and ETR2 are given in Table 4, divided for two subsets of companies, corresponding with the value 0 or 1 of PUBLIC. Again, the bold numbers indicate the number of firm-years observations. The results indicate that public companies have slightly lower ETRs, both for ETR 1 and ETR2, although this effect is small.

Table 4 Results for univariate descriptive statistics: mean and median ETRs for PUBLIC (1994-1999)

\begin{tabular}{|lrlcccccc|}
\hline & \multicolumn{4}{c}{ ETR1 } & \multicolumn{5}{c|}{ ETR2 } \\
\hline Expected sign & \multicolumn{3}{c}{-} & \multicolumn{1}{c|}{ - } & \\
\hline Statistic & FY & mean & median & std. dev. & FY & mean & median & std. dev. \\
PUBLIC $=0$ & $\mathbf{3 , 6 4 2}$ & $\mathbf{0 . 3 2 3}$ & 0.346 & 0.277 & $\mathbf{3 , 3 5 9}$ & 0.280 & 0.271 & 0.384 \\
PUBLIC $=1$ & $\mathbf{4 5 5}$ & 0.297 & 0.300 & 0.211 & $\mathbf{4 5 5}$ & 0.276 & 0.265 & 0.214 \\
\hline
\end{tabular}

For variable definitions see sections 3.4 .3 .1 and 3.4.3.2.

\footnotetext{
${ }^{10}$ Descriptive statistics for the FOREIGN variable are only provided for the non-zero observations.
} 
Table 5 shows correlations between ETR measures and the explanatory variables and between explanatory variables themselves ${ }^{11}$. The lower left panel reports ETR1 correlations, whereas the upper right panel reports ETR2 correlations.

Table 5, first, provides further univariate results supplementing the results in Tables 3 and 4 . The correlation between the two ETR measures and the explanatory variables are mostly insignificant, and when significant, small. Only ROA is significantly, albeit at a low level, related to ETRI. ETR2 is significantly related at a low level to CAPINT.

Table 5 Pearson correlations for ETR determinants (FY are 4,097 and 3,814 for ETR1/ETR2 respectively)

\begin{tabular}{|llllllll|}
\hline & ETR1 & fsize & capint & foreign & roa & lev & public \\
\hline ETR2 & & -0.005 & $-0.042^{* *}$ & 0.026 & 0.013 & -0.014 & -0.005 \\
fsize & -0.017 & & -0.009 & $0.428^{* *}$ & $-0.052^{* *}$ & -0.010 & $0.597^{* *}$ \\
capint & -0.020 & -0.003 & & $-0.149^{* *}$ & $-0.176^{* *}$ & $0.492^{* *}$ & $-0.101^{* *}$ \\
foreign & 0.002 & $0.434^{* *}$ & $-0.133^{* *}$ & & -0.023 & $-0.084^{* *}$ & $0.405^{* *}$ \\
roa & $-0.049^{* *}$ & $-0.062^{* *}$ & $-0.179^{* *}$ & -0.028 & & $-0.243^{* *}$ & $0.035^{*}$ \\
lev & -0.006 & -0.014 & $0.480^{* *}$ & $-0.083^{* *}$ & $-0.233^{* *}$ & & $-0.082^{* *}$ \\
public & -0.021 & $0.594^{* *}$ & $-0.096^{* *}$ & $0.407^{* *}$ & 0.028 & $-0.081^{* *}$ & \\
\hline
\end{tabular}

For variable definitions see sections 3.4.3.1 and 3.4.3.2.

*: significant at 5 percent level (two-tailed)

**: significant at I percent level (two-tailed)

Table 5 also shows, in general, not very high correlations between the company characteristics themselves, which should not create multicollinearity problems. A multivariate analysis is provided in the next section.

\subsubsection{OLS regression results}

Table 6 summarizes the OLS regression results for model (4), using the pooled data $^{12}$ sample for the 1994-1999 period. The results indicate that the overall explanatory power of model (4) is statistically significant for ETR 1 and 2 at the $1 \%$ level, though with very low adjusted R-square numbers. The CAPINT and LEV variables are significant in both ETR models, but LEV with the wrong sign. A possible explanation for this relationship is that companies with high levels of leverage, have relatively lower levels of pre-tax accounting income compared to taxable income, thus increasing ETR levels. Overall, the amount of variance in ETR 1/2 captured by the variables is small. So, the variances in ETR measures

\footnotetext{
"Nonparametric correlations using Spearman's rho are reported in appendix 3. The parametric (Pearson) and nonparametric correlations (Spearman) are similar.

${ }^{12}$ Annual (filtered) regression results for the sample period 1994-1999 are included in appendix 4. The annual results indicate a lower significance of the company characteristics and a better fit of the ETR2 model compared to the ETRI model. Based on the annual results only ROA in the ETR2 model is significant in all years.
} 
cannot be very well explained.

Although ETR 1 and ETR 2 appear to measure the same effective tax rate (see Table 2), they are related somewhat differently to company characteristics. A partial explanation for these differences is the larger dispersion of the cash flow based ETR measure.

Table 6 OLS regression model results for ETR 1/ETR 2 (ETR 1/2 FY are 4,097 and 3,814 respectively)

\begin{tabular}{|c|c|c|c|c|c|c|c|}
\hline \multirow[t]{2}{*}{ Variable } & \multirow{2}{*}{$\begin{array}{l}\text { Predicted } \\
\text { sign }\end{array}$} & \multicolumn{2}{|c|}{ Coefficient } & \multicolumn{2}{|c|}{ t-value ${ }^{13}$} & \multicolumn{2}{|c|}{ Significance } \\
\hline & & ETR1 & ETR2 & ETR1 & ETR2 & ETR1 & ETR2 \\
\hline Intercept & & 0.478 & 0.325 & 11.08 & 5.492 & $0.000^{* *}$ & $0.000^{* * *}$ \\
\hline FSIZE & $?$ & -0.012 & -0.032 & -2.937 & -0.606 & $0.003^{* * *}$ & 0.545 \\
\hline CAPINT & - & -0.129 & -0.371 & -5.156 & -10.58 & $0.000^{* *}$ & $0.000 * *$ \\
\hline FOREIGN & $?$ & 0.022 & 0.046 & 1.203 & 1.824 & 0.229 & 0.068 \\
\hline ROA & $?$ & -0.004 & 0.846 & -0.068 & 9.952 & 0.946 & $0.000^{* *}$ \\
\hline LEV & - & 0.097 & 0.290 & 2.880 & 6.170 & $0.004 * *$ & $0.000^{* *}$ \\
\hline PUBLIC & - & -0.012 & -0.037 & -0.659 & -1.483 & 0.510 & 0.138 \\
\hline$R$-square & (adj. $R$-square) & & & 0.011 & 0.059 & $(0.009$ & $0.058)$ \\
\hline$F$-statistic & (p-value) & & & 7.370 & 39.82 & $\left(0.000^{* *}\right.$ & $\left.0.000^{* *}\right)$ \\
\hline
\end{tabular}

For variable definitions see sections 3.4.3.1 and 3.4.3.2.

*: significant at $5 \%$-level (two-sided)

**: significant at $1 \%$-level (two-sided)

\subsubsection{Sensitivity analyses}

\subsubsection{Rank regression $(R R)$ results.}

To control for possible nonlinear relationships between company characteristics and ETR levels, a RR is used, with the variables classified into deciles. The results for this model are reported in Table 7.

\footnotetext{
${ }^{13}$ Fama and French (2000) adjust their t-values as their data have high first-order autocorrelation (around 0.5 ). The first-order autocorrelation (not reported) in this chapter approximates 0 , thus not necessitating the need for adjustment of t-values. Analyses of the regression errors (not reported) support this conclusion.
} 
Table 7 RR model results for ETR 1/ETR 2 (ETR 1/2 FY are 4,097 and 3,814 respectively)

\begin{tabular}{|c|c|c|c|c|c|}
\hline \multirow[t]{2}{*}{ Variable } & \multirow[t]{2}{*}{ Predicted sign } & \multicolumn{2}{|c|}{ F-value } & \multicolumn{2}{|c|}{ Significance } \\
\hline & & ETR1 & ETR2 & ETR1 & ETR2 \\
\hline Intercept & & 2,114 & 2,806 & $0.000^{* *}$ & $0.000^{* *}$ \\
\hline FSIZE & $?$ & $(-) 2.668$ & $(-) 2.386$ & $0.004 * *$ & $0.011 *$ \\
\hline CAPINT & - & $(-) 3.980$ & (-) 33.15 & $0.000^{* *}$ & $0.000^{* * *}$ \\
\hline FOREIGN & $?$ & $(-) 1.096$ & 2.318 & 0.362 & $0.013^{*}$ \\
\hline ROA & $?$ & 2.355 & 92.20 & $0.016^{*}$ & $0.000 * *$ \\
\hline LEV & - & 3.175 & 11.77 & $0.001 * *$ & $0.000^{* *}$ \\
\hline PUBLIC & - & $(-) 11.80$ & $(-) 11.65$ & 0.001 & $0.001^{* *}$ \\
\hline$R$-square & (adj. R-square) & 0.041 & 0.251 & $(0.031$ & $0.242)$ \\
\hline F-statistic & (p-value) & 3.877 & 28.03 & $\left(0.000^{* * *}\right.$ & $\left.0.000^{* *}\right)$ \\
\hline
\end{tabular}

For variable definitions see sections 3.4.3.1 and 3.4.3.2.

*: significant at $5 \%$-level (two-sided)

**: significant at $1 \%$-level (two-sided)

$(-)$ : indicates a negative relationship between this variable and ETR $1 / 2$ in the RR model.

The results indicate that both ETR 1 and ETR 2 RRs are significant. The explanatory power of the ETR1 model is still quite low, whereas the explanatory power of the ETR2 model has increased considerably. Again the CAPINT and LEV variables (LEV again with the wrong sign) are significant at the $1 \%$-level for both ETR1 and ETR2 models.

\subsubsection{Other sensitivity analyses.}

This section provides additional sensitivity analyses investigating the influence of (i) deleting NOL/NTE firm-years, (ii) deferred taxes, (iii) using a balanced panel, and (iv) industry effects. For each sensitivity analysis discussion is provided.

The analyses so far have used a sample excluding NOL/NTE firm-year observations. To the extent that this exclusion might influence the results, appendix 5 provides analyses for a dataset including the NOL/NTE firm-years, first using model (4), but second also including control variables as mentioned in section 3.4.3.1. The analyses are performed for both OLS and RR models. The results of the additional analyses concur with the findings in sections 3.5.1 and 3.5.2.

The statistical analyses so far have only used current taxes in the ETR 1/2 measure. To investigate whether deferred taxes impact the statistical analyses, tax expenses statistics for ETR 1/ETR 2 are calculated using the total tax expenses (i.e., current tax expense plus deferred tax charge). Descriptive statistics and OLS regression results for these total ETRs are reported in appendix 6 . Total ETR results suggest that total ETRs are similar to regular ETR1/2 definitions. OLS regression results for total ETRs are not consistently different from regular ETR1/2 definitions. 
The empirical results so far have been determined using a firm-years sample to provide the largest possible sample. A firm-years sample can include various categories of companies, including new and defaulting companies that often report extreme data. A balanced panel (which requires observations for all years for each company of the sample) may include "cleaner" (i.e., less extreme) data. Therefore, descriptive analyses and OLS regression using a balanced panel are also performed (reported in appendix 7). The results suggest that the balanced panel results for OLS regression are similar to the firm-years sample regression results. ETR levels of the balanced panel sample are almost identical to the firm-years sample.

Tax incentives do not necessarily have to be related to company characteristics, they can also be related to specific industries. To investigate this possible relationship, all industries (using BIK $\operatorname{codes}^{14}$ ) were selected with more than 75 firm-years observations available. For these industries, mean and median ETR 1/2 were calculated. These data are reported in appendix 8 .

Apart from companies in BIK code 501042 (automobile retail), the selected industries reveal no structural differences from the mean and median for the entire sample. This confirms the other findings, which, in general, show small differences between ETR $1 / 2$ and statutory tax rates.

\subsection{Summary and conclusions}

The aim of this chapter was to attempt to investigate the extent of horizontal equity of Dutch corporate income taxes. Six company characteristics were used to explain effective tax rates (ETRs) for a cross-sectional firm-years sample of Dutch companies for the years 1994 to 1999 . The company characteristics include company size, capital intensity, extent of foreign operations, company performance, leverage and being a public company.

The empirical results indicate that the Dutch corporate tax system provides relatively small amounts of tax incentives to companies. As far as these tax incentives can be related to company characteristics, the explained variation in ETR $1 / 2$ levels is small. These results point to the conclusion that the Dutch government provides limited tax incentives that mostly are difficult to explain with the investigated company characteristics in this chapter.

\footnotetext{
14 The BIK system is the standard classification system used by the Dutch Chambers of Commerce.
} 


\section{appendices}

1 Foreign sales variable: the effect of recoding

Results of descriptive statistics for recoded foreign sales and not-recoded foreign sales (not-filtered, filtered on ETR1, filtered on ETR2)

\begin{tabular}{|lllllll|}
\hline Statistic & \multicolumn{3}{l}{ recoded FOREIGN } & \multicolumn{3}{l|}{ FOREIGN (not-recoded) } \\
\hline Mean & 0.073 & 0.122 & 0.129 & 0.491 & 0.485 & 0.481 \\
Standard deviation & 0.211 & 0.261 & 0.267 & 0.307 & 0.309 & 0.308 \\
Median & 0.000 & 0.000 & 0.000 & 0.501 & 0.499 & 0.491 \\
Interquartile range & 0.000 & 0.000 & 0.051 & 0.536 & 0.537 & 0.539 \\
$F Y$ & 4,607 & 4,097 & 3,814 & 1,419 & 1,120 & 1,112 \\
\hline
\end{tabular}

For variable definitions see sections 3.4.3.1 and 3.4.3.2. 


\section{Pooled sample}

Results of descriptive statistics for pooled sample 1994-1999, ETR 1-filtered (FY are 4,097)

\begin{tabular}{|lcccccc|}
\hline Statistic & ETR 1 & FSIZE & CAPINT & FOREIGN & ROA & LEV \\
\hline Mean & 0.320 & 11.01 & 0.376 & 0.125 & 0.094 & 0.169 \\
Standard deviation & 0.276 & 1.425 & 0.197 & 0.266 & 0.074 & 0.148 \\
Median & 0.341 & 10.69 & 0.349 & 0.000 & 0.077 & 0.141 \\
Interquartile range & 0.155 & 1.419 & 0.271 & 0.020 & 0.079 & 0.209 \\
\hline
\end{tabular}

Results of descriptive statistics for pooled sample 1994-1999, ETR 2-filtered (FY are 3,814)

\begin{tabular}{|lcccccc|}
\hline Statistic & ETR 2 & FSIZE & CAPINT & FOREIGN & ROA & LEV \\
\hline Mean & 0.278 & 11.09 & 0.378 & 0.133 & 0.092 & 0.168 \\
Standard deviation & 0.377 & 1.439 & 0.197 & 0.271 & 0.072 & 0.147 \\
Median & 0.266 & 10.77 & 0.350 & 0.000 & 0.076 & 0.140 \\
Interquartile range & 0.268 & 1.465 & 0.269 & 0.060 & 0.079 & 0.208 \\
\hline
\end{tabular}

Results of descriptive statistics for unfiltered pooled sample 1994-1999 (FY are 4,607)

\begin{tabular}{|lccccccc|}
\hline Statistic & ETR 1 & ETR 2 & FSIZE & CAPINT & FOREIGN & ROA & LEV \\
\hline Mean & 0.356 & 0.301 & 11.09 & 0.377 & 0.133 & 0.092 & 0.168 \\
Std. dev. & 0.949 & 2.110 & 1.439 & 0.197 & 0.271 & 0.072 & 0.148 \\
Median & 0.341 & 0.266 & 10.77 & 0.350 & 0.000 & 0.076 & 0.140 \\
Interq. rang. & 0.156 & 0.270 & 1.460 & 0.269 & 0.060 & 0.079 & 0.208 \\
\hline
\end{tabular}

For variable definitions see sections 3.4.3.1 and 3.4.3.2. 


\section{Correlations}

Spearman correlations for ETR determinants (FY are 4,097 and 3,814 for ETR1/ETR2 respectively; ETR1 correlations in lower left panel, ETR2 correlations in upper right panel)

\begin{tabular}{|lllllllr|}
\hline & ETR1 & fsize & capint & foreign & roa & lev & public \\
\hline ETR2 & & $-0.037^{*}$ & $-0.278^{* *}$ & $0.051^{* *}$ & $0.408^{* *}$ & $-0.119^{* *}$ & -0.020 \\
fsize & $-0.098^{* *}$ & & -0.007 & $0.464^{* *}$ & $-0.036^{*}$ & 0.000 & $0.453^{* *}$ \\
capint & $-0.056^{* *}$ & 0.003 & & $-0.135^{* *}$ & $-0.188^{* *}$ & $0.486^{* *}$ & $-0.091^{* *}$ \\
foreign & $-0.038^{*}$ & $0.471^{* *}$ & $-0.120^{* *}$ & & 0.017 & $-0.083^{* *}$ & $0.421^{* *}$ \\
roa & 0.018 & $-0.041^{* *}$ & $-0.189^{* *}$ & 0.015 & & $-0.314^{* *}$ & $0.082^{* *}$ \\
lev & -0.018 & -0.005 & $0.478^{* *}$ & $-0.038^{* *}$ & $-0.306^{* *}$ & & $-0.062^{* *}$ \\
public & $-0.106^{* *}$ & $0.442^{* *}$ & $-0.086^{* *}$ & $0.423^{* *}$ & $0.077^{* *}$ & $-0.063^{* *}$ & \\
\hline
\end{tabular}

For variable definitions see sections 3.4.3.1 and 3.4.3.2.

*: significant at 5 percent level (two-tailed)

**: significant at 1 percent level (two-tailed) 


\section{Annual OLS regression results for the sample period 1994-1999}

1994 OLS regression model test results for ETR 1/ETR 2 (ETR 1/2 FY are 565 and 518 respectively)

\begin{tabular}{|c|c|c|c|c|c|c|c|}
\hline \multirow[t]{2}{*}{ Variable } & \multirow{2}{*}{$\begin{array}{l}\text { Predicted } \\
\text { sign }\end{array}$} & \multicolumn{2}{|c|}{ Coefficient } & \multicolumn{2}{|c|}{ t-value } & \multicolumn{2}{|c|}{ Significance } \\
\hline & & ETR1 & ETR2 & ETR1 & ETR2 & ETR1 & ETR2 \\
\hline Intercept & & 0.336 & 0.216 & 1.011 & 1.170 & 0.312 & 0.242 \\
\hline FSIZE & ? & 0.002 & 0.010 & 0.065 & 0.581 & 0.949 & 0.562 \\
\hline CAPINT & - & -0.233 & -0.441 & -1.191 & -3.901 & 0.234 & $0.000^{\text {** }}$ \\
\hline FOREIGN & ? & -0.149 & -0.063 & -0.978 & -0.736 & 0.328 & 0.462 \\
\hline ROA & $?$ & 0.694 & 0.979 & 1.717 & 4.056 & 0.086 & $0.000^{* *}$ \\
\hline LEV & - & -0.299 & 0.206 & -1.256 & 1.504 & 0.209 & 0.133 \\
\hline PUBLIC & - & 0.027 & -0.036 & 0.191 & -0.475 & 0.849 & 0.635 \\
\hline$R$-square & (adj. R-square) & & & 0.015 & 0.055 & $(0.007$ & $0.046)$ \\
\hline F-statistic & (p-value) & & & 1.795 & 6.109 & 0.097 & $0.000^{* *}$ \\
\hline
\end{tabular}

1995 OLS regression model test results for ETR 1/ETR 2 (ETR 1/2 FY are 656 and 600 respectively)

\begin{tabular}{|c|c|c|c|c|c|c|c|}
\hline \multirow[t]{2}{*}{ Variable } & \multirow{2}{*}{$\begin{array}{l}\text { Predicted } \\
\text { sign }\end{array}$} & \multicolumn{2}{|c|}{ Coefficient } & \multicolumn{2}{|c|}{ t-value } & \multicolumn{2}{|c|}{ Significance } \\
\hline & & ETR1 & ETR2 & ETR1 & ETR2 & ETR1 & ETR2 \\
\hline Intercept & & 0.240 & 0.734 & 0.842 & 1.701 & 0.400 & 0.089 \\
\hline FSIZE & $?$ & -0.005 & -0.060 & -0.200 & -1.489 & 0.841 & 0.137 \\
\hline CAPINT & - & 0.444 & -0.174 & 2.922 & -0.664 & $0.004^{* *}$ & 0.507 \\
\hline FOREIGN & $?$ & -0.098 & 0.182 & -0.795 & 0.979 & 0.427 & 0.328 \\
\hline ROA & ? & 0.198 & 1.628 & 0.601 & 3.105 & 0.548 & $0.002^{* * *}$ \\
\hline LEV & - & -0.103 & 0.150 & -0.495 & 0.443 & 0.621 & 0.658 \\
\hline PUBLIC & - & -0.063 & 0.089 & -0.508 & 0.488 & 0.612 & 0.625 \\
\hline$R$-square & \multirow{2}{*}{\multicolumn{3}{|c|}{$\begin{array}{l}\text { (adj. R-square) } \\
\text { (p-value) }\end{array}$}} & 0.015 & 0.018 & (0.008 & $0.010)$ \\
\hline F-statistic & & & & 2.060 & 2.209 & 0.056 & $\left.0.040^{*}\right)$ \\
\hline
\end{tabular}


1996 OLS regression model test results for ETR 1/ETR 2 (ETR 1/2 FY are 716 and 666 respectively)

\begin{tabular}{|c|c|c|c|c|c|c|c|}
\hline \multirow[t]{2}{*}{ Variable } & \multirow{2}{*}{$\begin{array}{l}\text { Predicted } \\
\text { sign }\end{array}$} & \multicolumn{2}{|c|}{ Coefficient } & \multicolumn{2}{|c|}{ t-value } & \multicolumn{2}{|c|}{ Significance } \\
\hline & & ETR1 & ETR2 & ETR1 & ETR2 & ETR1 & ETR2 \\
\hline Intercept & & 0.411 & -0.155 & 1.182 & -0.546 & 0.237 & 0.585 \\
\hline FSIZE & $?$ & -0.034 & 0.037 & -1.048 & 1.412 & 0.295 & 0.158 \\
\hline CAPINT & - & 0.316 & -0.286 & 1.585 & -1.719 & 0.113 & 0.086 \\
\hline FOREIGN & ? & -0.143 & -0.213 & -0.960 & -1.783 & 0.337 & 0.075 \\
\hline ROA & $?$ & 0.839 & 1.055 & 2.044 & 2.945 & $0.041^{*}$ & $0.003^{* *}$ \\
\hline LEV & - & 0.188 & 0.226 & 0.742 & 1.061 & 0.458 & 0.289 \\
\hline PUBLIC & - & 0.162 & -0.034 & 1.058 & -0.279 & 0.290 & 0.780 \\
\hline$R$-square & (adj. R-square, & & & 0.013 & 0.019 & $(0.006$ & $0.012)$ \\
\hline F-statistic & (p-value) & & & 1.817 & 2.564 & $(0.093$ & $\left.0.018^{*}\right)$ \\
\hline
\end{tabular}

1997 OLS regression model test results for ETR 1/ETR 2 (ETR 1/2 FY are 796 and 742 respectively)

\begin{tabular}{|c|c|c|c|c|c|c|c|}
\hline \multirow[t]{2}{*}{ Variable } & \multirow{2}{*}{$\begin{array}{l}\text { Predicted } \\
\text { sign }\end{array}$} & \multicolumn{2}{|c|}{ Coefficient } & \multicolumn{2}{|c|}{ t-value } & \multicolumn{2}{|c|}{ Significance } \\
\hline & & ETR1 & ETR2 & ETR1 & ETR2 & ETR1 & ETR2 \\
\hline Intercept & & 0.455 & 0.282 & 2.064 & 1.031 & $0.039^{*}$ & 0.303 \\
\hline FSIZE & $?$ & -0.016 & -0.009 & -0.800 & -0.341 & 0.424 & 0.733 \\
\hline CAPINT & - & -0.016 & -0.273 & -0.129 & -1.749 & 0.897 & 0.081 \\
\hline FOREIGN & $?$ & 0.027 & 0.240 & 0.294 & 2.155 & 0.769 & $0.031^{*}$ \\
\hline ROA & ? & 0.471 & 1.187 & 1.747 & 3.473 & 0.081 & $0.001^{* *}$ \\
\hline LEV & - & -0.102 & 0.315 & -0.654 & 1.609 & 0.514 & 0.108 \\
\hline PUBLIC & - & -0.038 & -0.077 & -0.377 & -0.635 & 0.706 & 0.526 \\
\hline$R$-square & \multirow{2}{*}{\multicolumn{3}{|c|}{$\begin{array}{l}\text { (adj. R-square) } \\
\text { (p-value) }\end{array}$}} & 0.006 & 0.024 & 0.000 & $0.017)$ \\
\hline$F$-statistic & & & & 1.005 & 3.515 & $(0.420$ & $0.002 * *)$ \\
\hline
\end{tabular}


1998 OLS regression model test results for ETR 1/ETR 2 (ETR 1/2 FY are 871 and 804 respectively)

\begin{tabular}{|c|c|c|c|c|c|c|c|}
\hline \multirow[t]{2}{*}{ Variable } & \multirow{2}{*}{$\begin{array}{l}\text { Predicted } \\
\text { sign }\end{array}$} & \multicolumn{2}{|c|}{ Coefficient } & \multicolumn{2}{|c|}{ t-value } & \multicolumn{2}{|c|}{ Significance } \\
\hline & & ETR1 & ETR2 & ETR1 & ETR2 & ETR1 & ETR2 \\
\hline Intercept & & 0.344 & 0.123 & 1.505 & 0.420 & 0.133 & 0.675 \\
\hline FSIZE & ? & 0.002 & 0.016 & 0.077 & 0.581 & 0.939 & 0.561 \\
\hline CAPINT & - & -0.213 & -0.568 & -1.706 & -3.541 & 0.088 & $0.000^{* *}$ \\
\hline FOREIGN & $?$ & 0.045 & 0.213 & 0.456 & 1.764 & 0.648 & 0.078 \\
\hline ROA & ? & 0.323 & 1.084 & 1.209 & 3.061 & 0.227 & $0.002^{* *}$ \\
\hline LEV & - & -0.233 & 0.199 & -1.502 & 1.003 & 0.133 & 0.316 \\
\hline PUBLIC & - & 0.049 & -0.135 & 0.456 & -1.028 & 0.648 & 0.304 \\
\hline$R$-square & \multirow{2}{*}{\multicolumn{3}{|c|}{$\begin{array}{l}\text { (adj. R-square) } \\
\text { (p-value) }\end{array}$}} & 0.014 & 0.031 & $(0.008$ & $0.025)$ \\
\hline$F$-statistic & & & & 2.352 & 4.899 & $\left(0.029^{*}\right.$ & $\left.0.000^{* *}\right)$ \\
\hline
\end{tabular}

1999 OLS regression model test results for ETR 1/ETR 2 (ETR 1/2 FY are 493 and 484 respectively)

\begin{tabular}{|lccrrrrr|}
\hline Variable & Predicted & \multicolumn{2}{c}{ Coefficient } & \multicolumn{2}{c|}{ t-value } & \multicolumn{2}{c|}{ Significance } \\
& sign & ETR1 & ETR2 & ETR1 & ETR2 & ETR1 & ETR2 \\
\hline Intercept & & 0.582 & -0.174 & 1.848 & -0.845 & 0.065 & 0.398 \\
FSIZE & $?$ & -0.036 & 0.025 & -1.286 & 1.353 & 0.199 & 0.177 \\
CAPINT & - & -0.267 & -0.350 & -1.425 & -2.846 & 0.155 & $0.005^{* *}$ \\
FOREIGN & $?$ & 0.076 & 0.187 & 0.532 & 2.075 & 0.595 & $0.038^{*}$ \\
ROA & $?$ & 0.990 & 2.053 & 2.242 & 6.976 & $0.025^{*}$ & $0.000^{* *}$ \\
LEV & - & 0.169 & 0.171 & 0.673 & 1.028 & 0.501 & 0.305 \\
PUBLIC & - & 0.086 & -0.096 & 0.623 & -1.104 & 0.533 & 0.270 \\
& & & & & & & \\
R-square & (adj. $R$-square) & & & 0.017 & 0.110 & $(0.007$ & 0.101 ) \\
F-statistic & (p-value) & & & 1.790 & 12.32 & 0.099 & $\left.0.000^{* *}\right)$ \\
\hline
\end{tabular}

For variable definitions see sections 3.4.3.1 and 3.4.3.2.

*; significant at $5 \%$-level (two-sided)

**: significant at $1 \%$-level (two-sided) 


\section{Sample including NOL/NTE firm-years}

OLS regression model test results for ETR 1/ETR 2 including NOL/NTE firm-years (ETR 1/2 FY are 5,355 and 4,905 respectively)

\begin{tabular}{|c|c|c|c|c|c|c|c|}
\hline \multirow[t]{2}{*}{ Variable } & \multirow{2}{*}{$\begin{array}{l}\text { Predicted } \\
\text { sign }\end{array}$} & \multicolumn{2}{|c|}{ Coefficient } & \multicolumn{2}{|c|}{ t-value } & \multicolumn{2}{|c|}{ Significance } \\
\hline & & ETR1 & ETR2 & ETR1 & ETR2 & ETR1 & ETR2 \\
\hline Intercept & & 0.416 & 0.197 & 3.696 & 1.725 & $0.000^{* * *}$ & 0.085 \\
\hline FSIZE & ? & -0.017 & 0.002 & -1.671 & 0.149 & 0.095 & 0.881 \\
\hline CAPINT & - & 0.045 & -0.332 & 0.773 & -5.085 & 0.440 & $0.000^{* *}$ \\
\hline FOREIGN & ? & -0.023 & 0.113 & -0.403 & 1.984 & 0.687 & $0.047^{*}$ \\
\hline ROA & $?$ & 0.540 & 1.203 & 4.022 & 8.707 & $0.000^{* *}$ & $0.000^{* *}$ \\
\hline LEV & - & -0.092 & 0.194 & -1.137 & 2.356 & 0.256 & $0.019^{*}$ \\
\hline PUBLIC & - & 0.041 & -0.048 & 0.750 & -0.884 & 0.453 & 0.377 \\
\hline$R$-square & \multirow{2}{*}{\multicolumn{3}{|c|}{$\begin{array}{l}\text { (adj. R-square) } \\
\text { (p-value) }\end{array}$}} & 0.005 & 0.025 & $(0.004$ & $0.024)$ \\
\hline$F$-statistic & & & & 4.006 & 19.29 & $(0.00)^{* * *}$ & $\left.0.000^{* *}\right)$ \\
\hline
\end{tabular}

OLS regression test results for ETR 1/ETR 2 including NOL/NTE firm-years and control variables (ETR $1 / 2$ FY are 5,355 and 4,905 respectively)

\begin{tabular}{|lcrrrrrr|}
\hline Variable & Pred. & \multicolumn{2}{c}{ Coefficient } & \multicolumn{2}{c}{ t-value } & \multicolumn{2}{c|}{ Significance } \\
& sign & ETR1 & ETR2 & ETR1 & \multicolumn{1}{c|}{ ETR2 } & ETR1 & ETR2 \\
\hline Intercept & & 0.562 & 0.266 & 4.703 & 2.141 & $0.000^{* *}$ & $0.000^{* *}$ \\
FSIZE & $?$ & -0.020 & 0.001 & -1.811 & 0.124 & 0.070 & 0.901 \\
CAPINT & - & -0.016 & -0.340 & -0.251 & -5.205 & 0.802 & $0.000^{* *}$ \\
FOREIGN & $?$ & -0.009 & 0.125 & -0.166 & 2.217 & 0.868 & $0.027^{*}$ \\
ROA & $?$ & -0.211 & 0.728 & -1.347 & 4.403 & 0.178 & $0.000^{* *}$ \\
LEV & - & -0.005 & 0.212 & -0.065 & 2.582 & 0.948 & $0.010^{*}$ \\
PUBLIC & - & 0.044 & -0.045 & 0.824 & -0.837 & 0.410 & 0.402 \\
Control variables: & - & & & & & \\
NOL & - & -0.834 & 0.609 & -1.804 & 1.234 & 0.071 & 0.217 \\
NTE & - & -0.557 & 0.059 & -1.260 & 0.123 & 0.208 & 0.902 \\
NOL*NTE & - & 1.700 & 0.135 & 16.38 & 1.249 & $0.000^{* *}$ & 0.212 \\
NOL*FSIZE & - & -0.027 & -0.066 & -0.269 & -1.472 & 0.529 & 0.141 \\
NTE*FSIZE & - & -0.011 & -0.037 & -0.280 & -0.830 & 0.780 & 0.407 \\
& & & & & & & \\
R-square & (adj. $R$-square) & & 0.067 & 0.036 & $(0.064$ & $0.034)$ \\
F-statistic & (p-value) & & & 32.06 & 15.55 & $\left(0.000^{* *}\right.$ & $0.000^{* *}$ ) \\
\hline
\end{tabular}


RR model test results for ETR 1/ETR 2 including NOL/NTE firm-years (ETR 1/2 FY are 5,355 and 4,905 respectively)

\begin{tabular}{|lcrrrr|}
\hline Variable & Predicted sign & \multicolumn{2}{c}{ F-value } & \multicolumn{2}{c|}{ Significance } \\
& & \multicolumn{1}{c}{ ETR1 } & \multicolumn{1}{c|}{ ETR2 } & \multicolumn{1}{c|}{ ETR1 } & ETR2 \\
\hline Intercept & & 2,551 & 3,520 & $0.000^{* *}$ & $0.000^{* *}$ \\
FSIZE & $?$ & $(-) 2.543$ & $(-) 1.644$ & $0.007^{* *}$ & 0.097 \\
CAPINT & - & $(-) 1.881$ & $(-) 28.20$ & 0.050 & $0.000^{* *}$ \\
FOREIGN & $?$ & $(-) 1.319$ & $(-) 1.996$ & 0.221 & $0.036^{*}$ \\
ROA & $?$ & 20.25 & 145.6 & $0.000^{* *}$ & $0.000^{* *}$ \\
LEV & - & 2.117 & 7.644 & $0.025^{* *}$ & $0.000^{* *}$ \\
PUBLIC & - & $(-) 10.76$ & $(-) 18.53$ & $0.001^{* *}$ & $0.000^{* *}$ \\
& & & & & \\
R-square & (adj. R-square) & 0.058 & 0.286 & $(0.049$ & $0.279)$ \\
F-statistic & (p-value) & 6.653 & 39.18 & $\left(0.000^{* *}\right.$ & $\left.0.000^{* *}\right)$ \\
\hline
\end{tabular}

RR test results for ETR 1/ETR 2 (filtered), including NOL/NTE firm-years and control variables (ETR $1 / 2$ FY are 5,355 and 4,905 respectively)

\begin{tabular}{|c|c|c|c|c|c|}
\hline \multirow[t]{2}{*}{ Variable } & \multirow[t]{2}{*}{ Predicted sign } & \multicolumn{2}{|c|}{ F-value } & \multicolumn{2}{|c|}{ Significance } \\
\hline & & ETR1 & ETR2 & ETR1 & ETR2 \\
\hline Intercept & & 424.0 & 398.9 & $0.000^{* *}$ & $0.000^{* *}$ \\
\hline FSIZE & $?$ & $(-) 2.833$ & $(-) 1.436$ & $0.011^{*}$ & 0.166 \\
\hline CAPINT & - & $(-) 2.506$ & $(-) 29.87$ & $0.007^{* *}$ & $0.000^{* *}$ \\
\hline FOREIGN & $?$ & $(-) 1.394$ & $(-) 2.312$ & 0.185 & $0.014^{*}$ \\
\hline ROA & $?$ & 3.008 & 75.71 & $0.001 * *$ & $0.000^{* *}$ \\
\hline LEV & - & 2.021 & 8.537 & $0.033^{*}$ & $0.000^{* *}$ \\
\hline PUBLIC & - & $(-) 8.328$ & $(-) 16.30$ & $0.004^{* *}$ & $0.000^{* *}$ \\
\hline \multicolumn{6}{|c|}{ Control variables: } \\
\hline NOL & - & $(-) 46.99$ & $(-) 1.137$ & $0.000^{* *}$ & 0.286 \\
\hline NTE & - & (-) 26.02 & $(-) 22.09$ & $0.000^{* *}$ & $0.000^{* *}$ \\
\hline $\mathrm{NOL} * \mathrm{NTE}$ & - & 391.7 & 61.52 & $0.000^{* *}$ & $0.000 * *$ \\
\hline NOL*FSIZE & - & 1.254 & (-) 0.837 & 0.257 & 0.582 \\
\hline NTE*FSIZE & - & (-) 1.024 & $(-) 1.209$ & 0.418 & 0.284 \\
\hline$R$-square & (adj. R-square) & 0.148 & 0.323 & $(0.136$ & $0.313)$ \\
\hline F-statistic & (p-value) & 12.46 & 31.90 & $\left(0.000^{* *}\right.$ & $\left.0.000^{* *}\right)$ \\
\hline
\end{tabular}

$(-)$ : indicates a negative relationship between this variable and ETR $1 / 2$ in the RR model.

For variable definitions see sections 3.4.3.1 and 3.4.3.2.

*: significant at $5 \%$-level (two-sided)

**: significant at $1 \%$-level (two-sided) 
Results of descriptive statistics for (filtered) gross ETR 1 and 2 (1994-1999)

\begin{tabular}{|lcc|}
\hline Statistic & ETR 1 & ETR 2 \\
\hline Mean & 0.329 & 0.258 \\
Standard deviation & 0.919 & 0.658 \\
Median & 0.349 & 0.250 \\
Interquartile range & 0.067 & 0.216 \\
FY & 4,097 & 3,814 \\
\hline
\end{tabular}

OLS regression test results for gross ETR 1/ETR 2 (filtered) (ETR 1/2 FY are 4,097 and 3,814 respectively)

\begin{tabular}{|lcrrrrrl|}
\hline Variable & \multirow{2}{*}{$\begin{array}{l}\text { Predicted } \\
\text { sign }\end{array}$} & \multicolumn{2}{c}{ Coefficient } & \multicolumn{2}{c|}{ t-value } & \multicolumn{2}{c|}{ Significance } \\
& ETR1 & ETR2 & ETR1 & ETR2 & ETR1 & ETR2 \\
\hline Intercept & & 0.237 & 0.081 & 1.527 & 1.114 & 0.127 & 0.265 \\
FSIZE & $?$ & 0.012 & 0.018 & 0.866 & 2.785 & 0.387 & $0.005^{* *}$ \\
CAPINT & - & -0.123 & -0.254 & -1.368 & -5.834 & 0.171 & $0.000^{* *}$ \\
FOREIGN & $?$ & -0.023 & -0.042 & -0.342 & -1.356 & 0.732 & 0.175 \\
ROA & $?$ & 0.200 & 0.876 & 0.927 & 8.283 & 0.354 & $0.000^{* *}$ \\
LEV & - & -0.026 & -0.070 & -0.211 & -1.203 & 0.833 & 0.229 \\
PUBLIC & - & -0.081 & -0.065 & -1.244 & -2.209 & 0.213 & $0.027^{*}$ \\
& & & & & & & \\
R-square & (adj. R-square) & & & 0.001 & 0.043 & $(0.000$ & $0.042)$ \\
F-statistic & (p-value) & & & 0.921 & 25.98 & $(0.478$ & $\left.0.000^{* *}\right)$ \\
\hline
\end{tabular}

For variable definitions see sections 3.4.3.1 and 3.4.3.2.

*: significant at $5 \%$-level (two-sided)

**: significant at $1 \%$-level (two-sided) 
Results of descriptive statistics for (filtered) ETR 1 and 2 (1994-1999) for balanced panel

\begin{tabular}{|lcc|}
\hline Statistic & ETR 1 & ETR 2 \\
\hline Mean & 0.334 & 0.273 \\
Standard deviation & 0.567 & 0.582 \\
Median & 0.341 & 0.266 \\
Interquartile range & 0.155 & 0.269 \\
FY & 3,810 & 3,804 \\
\hline
\end{tabular}

OLS regression test results for ETR 1/ETR 2 (filtered) for balanced panel data (ETR 1/2 FY are 3,810 and 3,804 respectively)

\begin{tabular}{|c|c|c|c|c|c|c|c|}
\hline \multirow[t]{2}{*}{ Variable } & \multirow{2}{*}{$\begin{array}{l}\text { Predicted } \\
\text { sign }\end{array}$} & \multicolumn{2}{|c|}{ Coefficient } & \multicolumn{2}{|c|}{ t-value } & \multicolumn{2}{|c|}{ Significance } \\
\hline & & ETR1 & ETR2 & ETR1 & ETR2 & ETR1 & ETR2 \\
\hline Intercept & & 0.575 & 0.246 & 6.274 & 2.651 & $0.000^{* * *}$ & $0.008^{* *}$ \\
\hline FSIZE & $?$ & -0.017 & 0.001 & -2.107 & 0.091 & $0.035^{*}$ & 0.928 \\
\hline CAPINT & - & -0.118 & -0.356 & $-2,170$ & -6.461 & $0.030^{*}$ & $0.000^{* *}$ \\
\hline FOREIGN & $?$ & 0.003 & 0.126 & 0.069 & 3.207 & 0.945 & 0.001 \\
\hline ROA & $?$ & -0.251 & 0.955 & -1.899 & 7.157 & 0.058 & $0.000^{* *}$ \\
\hline LEV & - & 0.118 & 0.330 & 1.629 & 4.472 & 0.103 & $0.000^{* *}$ \\
\hline PUBLIC & - & 0.006 & -0.070 & 0.148 & -1.796 & 0.883 & 0.073 \\
\hline$R$-square & (adj. R-square) & & & 0.004 & 0.029 & $(0.002$ & $0.028)$ \\
\hline$F$-statistic & (p-value) & & & 2.583 & 19.06 & $\left(0.017^{*}\right.$ & $0.000^{* *}$ \\
\hline
\end{tabular}

For variable definitions see sections 3.4.3.1 and 3.4.3.2.

*: significant at $5 \%$-level (two-sided)

**: significant at $1 \%$-level (two-sided) 


\section{Industry}

Mean and median ETR 1/2 for selected industries

\begin{tabular}{|llrrrrrr|}
\hline BIK & Industry & \multicolumn{2}{c}{ FY } & \multicolumn{2}{c}{ Mean } & \multicolumn{2}{c|}{ Median } \\
code & & ETR1 & ETR2 & ETR1 & ETR2 & ETR1 & ETR2 \\
\hline All & All companies & 4,097 & 3,814 & 0.321 & 0.279 & 0.341 & 0.270 \\
2811 & Metal construction & 83 & 76 & 0.397 & 0.318 & 0.340 & 0.324 \\
452111 & General construction & 435 & 381 & 0.285 & 0.247 & 0.316 & 0.230 \\
501042 & Automobile retail & 124 & 119 & 0.265 & 0.145 & 0.338 & 0.152 \\
521102 & Supermarkets & 79 & 80 & 0.290 & 0.227 & 0.333 & 0.294 \\
602423 & Road transport & 88 & 88 & 0.342 & 0.228 & 0.352 & 0.467 \\
\hline
\end{tabular}

For variable definitions see sections 3.4.3.1 and 3.4.3.2. 


\section{chapter 4}

\section{Implicit Taxes in the Corporate Sector: Evidence for the European Union}

\subsection{Introduction}

Tax legislators (governments) continuously provide tax incentives to various classes of targeted companies to induce these companies to alter their operating, investing, or financing decisions with the effect of reallocating resources towards outcomes that the governments prefer as part of their economic policy (Hines 1997).

Providing tax incentives to targeted companies may lead to differences in tax burdens between companies, i.e., companies are treated unequally corporate taxwise. Most previous tax accounting research studied differences in tax burdens by focusing on the average effective tax rate (ETR) measure (Shackelford and Shevlin 2001). ETRs are defined as (current) tax charge (derived from the company's financial statements) đivided by pre-tax financial accounting income (Callihan 1994). Thus, ETRs measure the amount of (explicit) taxes payable by the company, as a fraction of pre-tax accounting income (see also chapters 2 and 3 ).

However, this research has tended to overlook the fact that differences in explicit tax rates must, due to competition in the various markets a company operates in, lead to implicit taxes. Implicit taxes are the differences between pre-tax returns on fully taxed investments and the pre-tax returns on partially or tax-exempt risk-adjusted investments (Scholes and Wolfson 1992, Wilkie 1992) ${ }^{1}$. In fact, lower explicit taxes will thus lead to higher implicit taxes and vice versa ${ }^{2}$. Therefore, studying tax burdens should focus on total taxes across companies, both explicit

\footnotetext{
'A real-life example of implicit taxes would be the deductibility of interest costs of mortgage loans for personal income tax purposes in the Netherlands. This deductibility has eventually led to an increase in the prices of houses compared to neighboring countries which do not have such a facility. These higher prices can be attributed to the effect of implicit taxes.

${ }^{2}$ Absent of market frictions and risk differences (Scholes and Wolfson 1992).
} 
and implicit tax burdens.

Only a relatively small number of earlier studies have investigated implicit taxes. The present chapter will focus on implicit taxes in the corporate sector in the European Union (EU).

This chapter investigates a fuller set of implicit tax affecting variables. Not only are tax incentives investigated as an implicit tax creating variable, but also product and factor market competition vulnerability as variables impacting the lower (higher) before-tax returns of tax (dis)favoured companies.

The results in this chapter indicate that implicit taxes play an important role in explaining differences in pre-tax financial accounting returns across the European Union. The strength of the negative relationship is close to the expected (theoretical) value of 1 . Furthermore, the results also provide significant support for the relevance of the proxies for product and factor market competition ${ }^{3}$ in explaining levels of implicit taxes and for differences in statutory tax rates impacting levels of pre-tax returns between countries.

In paragraph two of this chapter, previous research will be addressed along with the hypotheses. Paragraph three specifies the model and data used in this study. Paragraph four will address the empirical analyses of the hypotheses. Finally, paragraph five will provide a conclusion.

\subsection{Background and hypotheses}

\subsubsection{Background}

Previous empirical tax accounting research has only assessed the empirical importance of implicit taxes to a limited degree. The theoretical framework of implicit taxes was developed by Scholes and Wolfson (1992). This framework was used to develop the model used in earlier research and in this chapter. Empirical studies that use this framework either investigate specific or corporate settings. Published research in corporate settings ${ }^{4}$ is in Wilkie (1992) and Callihan and White (1999). Corporate setting research was initiated by Wilkie (1992). This chapter has a corporate setting.

When discussing implicit taxes, the most important notion is the tax incentive concept. Tax incentives are cross-sectional and intertemporal differences in the companies' exclusions, deductions, and other items that cause taxable income to diverge from pre-tax economic income (Wilkie 1988; see also earlier chapters). Due to the existence of positive (i.e., decreasing taxable income) or negative tax

\footnotetext{
${ }^{3}$ These variables proxy for the effect of market frictions in reducing the implicit taxes relationship.

${ }^{4}$ Examples of studies in specific settings can be found in section 3.3 of Shackelford and Shevlin (2001).
} 
incentives, implicit taxes arise, since the marketplace will bid up (bid down) the prices of tax-favoured (disfavoured) investments, and thereby lower (increase) the pre-tax investments' returns (Scholes and Wolfson 1992). Thus, implicit taxes are not paid (directly) to the tax authorities, but by the beneficiaries of the tax incentive(s) to capital, factor and product market agents (Frank 1994, Stiglitz 1997) who receive (part of) these incentives while the intended beneficiaries end up receiving a lower pre-tax return.

Implicit taxes on investments are defined as the difference between the before-tax return on a fully taxable investment and the before-tax return on a notfully taxed alternative investment in competitive markets (Scholes and Wolfson 1992). Since investors will demand higher returns for riskier investments, the proposition is about risk adjusted returns.

Generally speaking, an investor will thus not only pay explicit taxes, but also implicit taxes. In a competitive setting, there should be a perfectly negative (riskadjusted) association between explicit and implicit taxes. The total taxes for an investment, that is explicit taxes plus implicit taxes, should be equal across investments over time (when controlling for risk differences), otherwise tax arbitrage possibilities will exist (Scholes and Wolfson 1992). Such tax arbitrage possibilities would lead to abnormal returns, which are not sustainable in the long run $^{5}$ (Goolsbee 1998, Scherer and Ross 1990).

In the first paper to test this theoretical framework on implicit taxes in a corporate setting, Wilkie (1992) has empirically tested the implicit tax hypothesis by investigating the relationship between pre-tax return on equity (as proxy for pretax economic income) and the pre-tax equivalent of tax incentives ${ }^{6}$ on equity (as proxy for tax incentives). He finds a consistent and statistically significant negative relation between pre-tax return and tax incentives. However, the actual relationship found was weaker than hypothesised by the implicit tax hypothesis for a competitive market (the coefficient should be -1). But, Wilkie (1992) did not control for factors that cause tax incentives to 'leak away'. This omission affects the understanding why the relationship is as reported by Wilkie (1992).

A small number of other studies have also, to some extent, studied implicit taxes in a corporate setting. In an earlier study, Wilkie (1988) found that "ETR variations are caused by differences in both tax incentives and income whenever tax incentives and income are not perfectly correlated", thereby providing support for the implicit tax hypothesis.

Recent published research in the corporate setting is in Callihan and White (1999). Not only is the existence of implicit taxes investigated, Callihan and White also use the company's market power as a proxy for product market frictions. They

\footnotetext{
${ }^{5}$ On the other hand, tax arbitrage is limited by the related fixed and marginal costs (Erickson, Goolsbee, and Maydew 2002).

${ }^{6}$ Wilkie (1992) uses the expression "tax subsidies", but in line with the other chapters, this chapter uses "tax incentives" throughout.
} 
find support for the existence of implicit taxes (a negative relationship between level of tax incentives and pre-tax returns) as well as for product market structure imperfections negatively impacting the implicit taxes relationship. Callihan and White (1999) indicate that differences in factor markets might also affect the level of implicit taxes, but note their own lack of focus on these factor markets (i.e., input markets) mainly due to lack of data.

Shackelford and Shevlin (2001) provide an overview of research on implicit taxes in both specific settings as well as in corporate settings.

Summarising the existing implicit tax accounting literature, previous studies on implicit taxes in the corporate sector have found evidence relating to the implicit tax hypothesis as set forth by Scholes and Wolfson (1992). These studies have also found limited evidence for factors influencing the implicit tax relationship. The scope of these studies is limited as they only (i) use data on the US corporate setting and (ii) take only partial account of implicit tax causing variables. These limitations are addressed in this chapter. That is, this chapter (a) compares the implicit tax relationship between European Union countries, and (b) includes both product market and factor market proxies ${ }^{7}$ to capture variables influencing the implicit tax relationship. The next paragraph describes three specific aspects relating to the research design in this chapter: (i) market frictions, specifically product and factor market frictions, (ii) tax rate differences within and between the European Union member states, and (iii) risk differences.

\subsubsection{Hypotheses}

\subsubsection{Product and factor market frictions.}

Scholes and Wolfson (1992) demonstrate that in a fully competitive market risk-adjusted after-tax economic returns will equalize (see also Fama and French (2000) and Stigler (1963)). If governments impose differing taxes ${ }^{8}$ on such returns, the before-tax economic returns will reflect the "implicit taxes", that is lower (higher) before-tax economic returns equivalent to the lower (higher) corporate taxation. To test this hypothesis in a corporate setting Wilkie (1992) examined the relationship between pre-tax return on equity (PTROE) (a proxy for before-tax economic return) and pre-tax equivalent of tax incentives received on equity (PTTIE) ${ }^{9}$. Wilkie's (1992) results show the expected significant negative relationship between PTROE and PTTIE in the US corporate setting. Wilkie (1992)

\footnotetext{
${ }^{7}$ This study does not include proxies for capital and entrepreneurship markets (Frank 1994) as variables potentially affecting the implicit tax relationship, due to the measurement and availability problems associated with these variables. Goolsbee (1998) provides a useful example of a capital market proxy, which is, however, not available in this setting.

${ }^{8}$ Including differences in tax rates, but also in taxable incomes, deductions, etc.

${ }^{9}$ Wilkie (1992) defines PTTIE as the ratio of tax incentives (pre-tax income multiplied by the highest statutory tax rate, minus current tax expense) to stockholders' equity, divided by one minus the highest statutory tax rate.
} 
uses a financial statement based accounting measure (PTROE) as a proxy for economic income. Due to the absence of economic income measures, accounting measures are also used in this chapter.

In the EU corporate setting, this implicit tax relationship is expected to hold $^{10}$, stated in hypothesis one:

\section{H1 There is a negative relationship between PTROE and PTTIE.}

Callihan and White (1999) follow up on Wilkie's (1992) research, incorporating differences in product market competition as explanation for the nonunity relationship Wilkie (1992) found. A limitation in their study is the lack of control for differences in factor market competition (Callihan and White 1999). Scherer and Ross (1990, p. 206) state that both high (low) factor market competition and low (high) product market competition relate to higher (lower) after-tax profitability levels, because such differences in competition cannot be fully mitigated by arbitrage.

In this chapter, both the influence of differences in product and factor market competition is investigated, as well as the combined effect of product/factor market competition and PTTIE on the PTROE levels. The factor market consists of two important submarkets: the labour and supplier market. Proxies for both submarkets are included in this study. Hypothesis two and three a and b state the expected relationship.

H2 There is a more negative relationship between PTROE and PTTIE for companies experiencing high product market competition.

H3a There is a more negative relationship between PTROE and PTTIE for companies experiencing low labour market competition.

\section{$\mathrm{H} 3 \mathrm{~b}$ There is a more negative relationship between PTROE and PTTIE for companies experiencing low supplier market competition.}

The reason for the opposite relations in hypotheses 2 and 3 is that in situations of low product market competition, the companies can earn higher after tax returns and thus "hold on" to the tax incentives, whereas in situations of low factor market competition, factor market agents (i.e., employees and suppliers) will "force" the companies to "give up" their tax incentives.

\subsubsection{Tax rate differences.}

In contrast to the US setting, the EU offers a wide variety of taxable incomes

\footnotetext{
${ }^{10}$ As the EU is more diverse than the U.S. in terms of accounting, economic, and legal differences, hypothesis 1 is expected to be less strong in the EU compared to the U.S.
} 
that apply differing tax rates. Each EU member state has its own taxable income and statutory corporate tax rate(s).

Two separate effects can be expected. First, if tax rates ${ }^{11}$ are higher, this will raise the cost of capital (Guenther and Willenborg 1999). A higher cost of capital will in its turn increase entry barriers (Scherer and Ross 1990). In case of higher entry barriers, fewer market participants will be able to enter the market, thus increasing the concentration ratio in this particular market and lowering the level of competition (Scherer and Ross 1990). In situations of decreased competition, as already explained in relation to hypothesis 2 , the arbitrage effect is expected to be less strong and thus a less strong negative relationship between PTROE and PTTIE is expected. This effect is supported by the findings of Feldstein, Dicks-Mireaux and Poterba (1983).

Second, if tax rates are higher, this will increase the relative value of tax incentives to companies. As a result of this, the arbitrage process should be strengthened and thus a stronger relationship between PTROE and PTTIE is expected.

For the Netherlands, the hypothesis is stated without direction.

\section{H4 There is a relationship between PTROE and PTTIE for companies experiencing deviating statutory tax rates.}

\subsubsection{Risk.}

According to Scholes and Wolfson (1992), risk differences affect the implicit tax relationship. This necessities risk controls when comparing implicit tax levels between companies with different risk levels. In the current research design, implicit and explicit tax levels are investigated per company, thus eliminating the need for risk controls, as one company will have one overall risk level.

\subsection{Research method}

\subsubsection{Data}

Data are collected from the Osiris database (version 22, October 2002), which contains financial statement derived data on 27,336 public companies worldwide. The most recent years available are used in the selection of companies. These are the years 1995-2000. To select the sample, the following search criteria are used:

\footnotetext{
"The standard measure for tax rates is the statutory tax rate (STR) as stated in the applicable tax laws. Due to differences in taxable incomes, deductions, and the like, effective tax rates (ETRs) are not similar to STRs. Although research (Bond and Chennells 2000, Devereux 1989, and Single 1999) indicates that ETRs may be more relevant than STRs in determining the cost of capital, this study uses the STRs as standard proxy for tax rate differences.
} 
Table $1 \quad$ Selection criteria

\begin{tabular}{|clrr|}
\hline Step & Description & Not available & Available \\
\hline 1 & Companies on Osiris & & 27,336 \\
2 & And EU domicile & 20,901 & 6,435 \\
3 & And not financial companies & 586 & 5,849 \\
4 & And active & 42 & 5,807 \\
5 & And consolidated statement & 104 & 5,703 \\
6 & Data available & 278 & 5,425 \\
\hline
\end{tabular}

The selection starts with all companies available on Osiris. Then the companies with their domicile in the EU are selected. Next all financial companies are deleted because they have a deviating financial statement format. Financial companies are defined as those companies operating in SIC 60-64 industries ${ }^{12}$. In the next step inactive companies ${ }^{13}$ are deselected. Only companies with a consolidated statement are selected. These selection steps result in a data sample of 5,703 companies, of which 5,425 companies ( 23,256 firm-years) remain when the availability of data ${ }^{14}$ for the main model (= model 1 , see next section) is checked ${ }^{15}$. The subsequent analyses are based on those companies that report data for all relevant variables. This reduces the firm-years sample from 23,256 to 8,586 firmyears.

The analyses in this chapter are based on pooled firm-year (FY) observations for the period 1995-2000. Results from such statistical analyses may be affected by serial correlation in the data. To facilitate comparison between the pooled sample and the annual samples, the appendices include annual descriptive and annual OLS regression results.

\subsubsection{Model(s) and variables}

From hypothesis 1, a negative relationship between PTROE and PTTIE is expected, as stated in (1), where i denotes the company subscript en $t$ the time subscript for one of the years 1995-2000. This relationship was examined by Wilkie (1992) and Callihan and White (1999).

\footnotetext{
${ }^{12}$ These industries are, SIC 60 : depository institutions, SIC 61 : nondepository institutions, SIC 62: security and commodity brokers, SIC 63: insurance carriers, and SIC 64: insurance agents, brokers \& service.

${ }^{13}$ Inactive companies are companies included on the Osiris database, which do not carry out active business operations.

${ }^{14}$ The availability of missing data varies per country. The main causes for non-availability of data are either the non-reporting by companies or the immateriality of such items.

${ }^{15}$ Of the final 5,425 companies, 5,377 companies are listed on a European Union stock exchange, and 1,985 companies report model 1 data for all available years.
} 
This model is expanded to include controls for product market competition differences as such differences affect company profitability and distort the implicit tax relationship (Scherer and Ross 1990, Scholes and Wolfson 1992). Callihan and White (1999) used both market share (MS) and market concentration ratio $\mathrm{C}^{16}$ as proxies for the product market factor. However, due to the limited availability of the relevant industry sales data in the EU public domain, it is difficult to use these proxies in this study. Bowen, DuCharme, and Shores (1995) provide an alternative variable to measure the relationship between a company and its customers. They argue that companies providing (more) unique products are better able to differentiate themselves from companies with more common products. Such companies can demand premium prices and achieve higher returns. Bowen et. al. (1995) propose relative Research \& Development (R\&D) expenditure (R\&D expense over company size) as proxy for the uniqueness of the product or service. This study will also use relative R\&D expenditure as a proxy for the product market competition, stated in (2).

$$
\text { PTROE }_{t i}=\alpha_{t i}+\beta_{1} \text { PTTIE }_{t i}+\beta_{2} \text { PTTIE }^{*} R \& D_{t i}+\beta_{3} R \& D_{t i}+\varepsilon
$$

The implicit tax relationship is not only affected by product market competition differences, but also by factor market competition differences (Scherer and Ross 1990), as such differences impact the relative company profitability. Two main measures are used to capture factor market competition differences (Scherer and Ross 1990): material costs and payroll costs ${ }^{17}$ A frequently used proxy for material costs is the capital over sales ratio (Scherer and Ross 1990, p. 419). However, as the Osiris database contains a 'material expense' (ME) variable, this variable $^{18}$ is used. For payroll costs (PC), the 'Salaries and benefits expenses' measure ${ }^{19}$ available on Osiris is used, stated in (3).

$$
\begin{aligned}
& \text { PTROE }_{t i}=\alpha_{t i}+\beta_{1} \text { PTTIE }_{t i}+\beta_{2} \text { PTTIE }^{2} \& D_{t i}+\beta_{3} R \& D_{t i}+\beta_{4} \text { PTTIE* ME }_{t i}+ \\
& \beta_{5} \text { ME }_{t i}+\beta_{6} \text { PTTIE*PC }_{t i}+\beta_{7} \text { PC }_{t i}+\varepsilon
\end{aligned}
$$

In this study, the implicit tax relationship is tested across the EU member states. As these member states apply differing tax rates this has a potential effect on the implicit tax relationship as higher tax rates lead to lower factor market competition (Bartelsman and Doms 2000). Here, the statutory tax rate (STR)

\footnotetext{
${ }^{16}$ Concentration index $\mathrm{C} 4$ is defined as the cumulative market share of the four largest companies in four-digit level SIC categories (Callihan and White 1999).

${ }^{17}$ To take size differences in account, both measures are scaled by a measure of company size.

${ }^{18}$ Additional analyses (not reported here) indicate that ME is better able to capture PTROE differences than the capital over sales ratio.

${ }^{19}$ Both measures are comparable to the measures used by Bowen, DuCharme, and Shores (1995).
} 
differences are used to capture country differences, as well as capturing additional factor market competition differences. Thus, the statutory tax rates ${ }^{20}$ are included in model (4).

$$
\begin{aligned}
& \text { PTROE }{ }_{\mathrm{ti}}=\alpha_{\mathrm{ti}}+\beta_{1} \text { PTTIE }_{\mathrm{i}}+\beta_{2} \text { PTTIE }^{*} \& \mathrm{D}_{\mathrm{ti}}+\beta_{3} \text { R \& } \mathrm{D}_{\mathrm{ti}}+\beta_{4} \mathrm{PTTIE}^{*} \mathrm{ME}_{\mathrm{ti}}+ \\
& \beta_{5} \mathrm{ME}_{\mathrm{ti}}+\beta_{6} \text { PTTIE}^{*} \text { PC }_{t \mathrm{i}}+\beta_{7} \mathrm{PC}_{\mathrm{ti}}+\beta_{8} \text { PTTIE }^{*} \mathrm{STR}_{\mathrm{ti}}+\beta_{9} \mathrm{STR}_{\mathrm{ti}}+\varepsilon
\end{aligned}
$$

Below, in Table 2, the definitions and Osiris codes are stated for the various variables in the implicit tax models. Pre-tax return on equity (PTROE) is calculated by dividing financial accounting income before taxes over the average of owner's equity at the beginning and end of the year. The grossed-up pre-tax equivalent of tax incentives on owner's equity (PTTIE) is calculated by first expressing the pretax equivalent of tax incentives, which is defined as the difference between the expected corporate income taxes to be paid (financial accounting income multiplied by STR) and the tax expense. This pre-tax equivalent of tax incentives (PTTI) is then divided by grossed-up owner's equity to derive at the grossed-up pre-tax equivalent of tax incentives on owner's equity (PTTIE). The proxies for the product (R\&D expenses), and factor market (material costs and payroll costs) are scaled by average total assets ${ }^{21}$ to enhance comparability across companies. Note, that in model (4) the variables R\&D, PC, ME, and STR are used as control variables (with STR being a dummy variable capturing country differences), with the interaction variables being the variables of interest.

\footnotetext{
${ }^{20}$ As each country has one STR, this measure effectively acts as a dummy variable capturing country differences in the PTROE-PTTIE relationship.

${ }^{21}$ Bowen et.al. (1995) report the qualitative similarity of total assets as scaler to other scalers.
} 
Table 2 Definitions and Osiris codes/mnemonics

\begin{tabular}{|c|c|c|}
\hline Variable & Definition & Osiris codes/mnemonics \\
\hline $\mathrm{OE}$ & $\begin{array}{l}\text { Average of owners' equity at the } \\
\text { beginning and end of the year }\end{array}$ & $\begin{array}{l}\text { "common equity" } \\
(30090)\end{array}$ \\
\hline PTI & $\begin{array}{l}\text { Financial accounting income } \\
\text { before taxes }\end{array}$ & $\begin{array}{l}\text { "pretax income" } \\
(30260)\end{array}$ \\
\hline PTROE & Pre-tax return on owners' equity & $\frac{\mathrm{PTI}}{\mathrm{OE}} \frac{30260}{30090}$ \\
\hline STR & Statutory tax rate (STR) & $\begin{array}{l}\text { Retrieved from Buijink, Janssen, and Schols } \\
2001 \text { and KPMG Corporate Tax Rate } \\
\text { Survey } 2001\end{array}$ \\
\hline TE & Tax expense & $\begin{array}{l}\text { "income taxes" } \\
(30265)\end{array}$ \\
\hline PTTI & $\begin{array}{l}\text { Pre-tax equivalent of tax } \\
\text { incentives }\end{array}$ & $\begin{array}{l}\left(\mathrm{PTI}^{*} \mathrm{STR}\right)-\mathrm{TE} \\
\left(30260^{*} \mathrm{STR}\right)-30265\end{array}$ \\
\hline PTTIE & $\begin{array}{l}\text { Grossed-up pre-tax equivalent of } \\
\text { tax incentives on owners' equity } \\
\text { (PTTI/OE) }\end{array}$ & $\frac{\left(\frac{\mathrm{PTTI}}{\mathrm{OE}}\right)}{(1-\mathrm{STR})} \frac{\left(\frac{P T T I}{30090}\right)}{(1-S T R)}$ \\
\hline$R \& D^{22}$ & $\begin{array}{l}\text { Relative Research \& } \\
\text { Development expenses }\end{array}$ & $\begin{array}{l}\text { "R\&D expense"/"average total assets" } \\
22020 /\left(\text { average }\left(30050_{t}+30050_{t-1}\right)\right)\end{array}$ \\
\hline ME & Relative material costs & $\begin{array}{l}\text { "material expense"/"average total assets" } \\
22155 /\left(\text { average }\left(30050_{t}+30050_{t-1}\right)\right)\end{array}$ \\
\hline PC & Relative payroll costs & $\begin{array}{l}\text { "salaries and benefits expenses"/"average } \\
\text { total assets" } \\
22165 /\left(\text { average }\left(30050_{t}+30050_{t-1}\right)\right)\end{array}$ \\
\hline
\end{tabular}

${ }^{22}$ This variable shows a relatively large number of cases with missing data. Based on e.g., Hanlon, Rajgopal, and Shevlin (2002) such missing data are recoded " 0 ". All subsequent analyses are based on this recoded variable. Appendix 1 provides sensitivity analyses supporting this recoding. 


\subsection{Results}

\subsubsection{Descriptive and univariate results}

Below information is provided on the descriptive and univariate results. Table 3 displays the relative number of firm-years in 1 digit SIC industry categories ${ }^{23}$ as well as the total number of firm-years for each EU member state.

Table 3 shows a number of countries with few firm-years in the sample. Notably, Austria, Denmark, Greece, Ireland, Luxembourg, Portugal, Spain, and Sweden ${ }^{24}$ have each less than 300 firm-years in the sample and are therefore excluded from subsequent country-analysis ${ }^{25}$. Predominant among the companies are SIC classifications 2 and 3 (both manufacturing), which account for $56.4 \%$ of all companies in the sample. This indicates that the current sample is quite evenly spread across one-digit SIC codes, as both Wilkie (1992) and Callihan and White (1999) derived approximately $75 \%$ of their samples from companies in SIC classification 2 and 3.

To restrict the influence of extreme observations on the subsequent (multivariate) analysis, the PTROE and PTTIE variables were filtered. All observations removed more than two standard deviations from the mean of respectively PTROE and PTTIE were deleted from the file (Buijink, Janssen, and Schols 2002). This filter reduced the dataset by a total of 204 firm-year observations to 8,382 firm-years. All subsequent analyses use this filtered dataset. Appendix 2 provides descriptive statistics for the filtered and unfiltered pooled sample.

\footnotetext{
${ }^{23}$ SIC 0 is agriculture, forestry and fishing, SIC 1 is mining and construction, SIC 2 and 3 are manufacturing, SIC 4 is transportation and public utilities, SIC 5 is wholesale trade and retail trade, SIC 6 is finance, insurance and real estate, SIC 7 and 8 are services, and SIC 9 is public administration and non-classifiable establishments.

${ }^{24}$ These countries have the smallest stock exchanges in the European Union. Their lack of public companies has also been apparent in earlier research. See, for example, Buijink, Janssen and Schols 2001.

${ }^{25}$ To restrict the loss of company-observations, observations from these countries are included in the non-country specific statistical analyses.
} 
Table 3 Total number of firm-years and number of firm-years in 1-digit SIC industries

\begin{tabular}{|c|c|c|c|c|c|c|c|c|c|c|c|}
\hline Country & Firm-Years & SIC 0 & SIC 1 & SIC 2 & SIC 3 & SIC 4 & SIC 5 & SIC 6 & SIC 7 & SIC 8 & SIC 9 \\
\hline Austria & 296 & $0.00 \%$ & il. $5 \%$ & $28.4 \%$ & $25.7 \%$ & $13.5 \%$ & $12.5 \%$ & $3.40 \%$ & $3.00 \%$ & $2.00 \%$ & $0.00 \%$ \\
\hline Belgium & 447 & $1.60 \%$ & $8.30 \%$ & $27.5 \%$ & $23.5 \%$ & $12.3 \%$ & $10.1 \%$ & $4.70 \%$ & $11.6 \%$ & $0.40 \%$ & $0.00 \%$ \\
\hline Denmark & 182 & $0.00 \%$ & $3.30 \%$ & $26.4 \%$ & $49.5 \%$ & $8.20 \%$ & $8.80 \%$ & $0.00 \%$ & $2.70 \%$ & $1.10 \%$ & $0.00 \%$ \\
\hline Finland & 393 & $0.00 \%$ & $3.60 \%$ & $27.7 \%$ & $31.6 \%$ & $16.0 \%$ & $9.90 \%$ & $1.50 \%$ & $7.610 \%$ & $2.00 \%$ & $0.00 \%$ \\
\hline France & 2.276 & $1.20 \%$ & $4.70 \%$ & $21.8 \%$ & $31.5 \%$ & $6.70 \%$ & $12.7 \%$ & $4.10 \%$ & $14.3 \%$ & $2.90 \%$ & $0.10 \%$ \\
\hline Germany & 2,259 & $0.00 \%$ & $4.80 \%$ & $20.6 \%$ & $36.0 \%$ & $12.9 \%$ & $7.40 \%$ & $2.60 \%$ & $12.2 \%$ & $3.50 \%$ & $0.00 \%$ \\
\hline Greece & 0 & $0.00 \%$ & $0.00 \%$ & $0.00 \%$ & $0.00 \%$ & $0.00 \%$ & $0.00 \%$ & $0.00 \%$ & $0.00 \%$ & $0.00 \%$ & $0.00 \%$ \\
\hline Ireland & 6 & $0.00 \%$ & $0.00 \%$ & $100 \%$ & $0.00 \%$ & $0.00 \%$ & $0.00 \%$ & $0.00 \%$ & $0.00 \%$ & $0.00 \%$ & $0.00 \%$ \\
\hline ltaly & 617 & $0.00 \%$ & $5.70 \%$ & $26.4 \%$ & $34.8 \%$ & $15.4 \%$ & $3.40 \%$ & $3.40 \%$ & $9.90 \%$ & $0.60 \%$ & $0.30 \%$ \\
\hline Luxembourg & 25 & $0.00 \%$ & $0.00 \%$ & $0.00 \%$ & $36.0 \%$ & $52.0 \%$ & $12.0 \%$ & $0.00 \%$ & $0.00 \%$ & $0.00 \%$ & $0.00 \%$ \\
\hline Netherlands & 406 & $0.00 \%$ & $7.40 \%$ & $39.2 \%$ & $31.0 \%$ & $10.1 \%$ & $7.60 \%$ & $1.50 \%$ & $2.70 \%$ & $0.50 \%$ & $0.00 \%$ \\
\hline Portugal & 169 & $3.00 \%$ & $15.4 \%$ & $32.0 \%$ & $15.4 \%$ & $10.1 \%$ & $13.0 \%$ & $6.50 \%$ & $4.70 \%$ & $0.00 \%$ & $0.00 \%$ \\
\hline Spain & 249 & $0.00 \%$ & $19.3 \%$ & $20.96 \%$ & $23.3 \%$ & $19.7 \%$ & $6.00 \%$ & $7.60 \%$ & $3.20 \%$ & $0.00 \%$ & $0.00 \%$ \\
\hline Siveden & 259 & $1.20 \%$ & $4.20 \%$ & $24.7 \%$ & $19.7 \%$ & $11.6 \%$ & $6.20 \%$ & $3.90 \%$ & $25.9 \%$ & $2.70 \%$ & $0.00 \%$ \\
\hline UK & 798 & $0.00 \%$ & $6.80 \%$ & $26.6 \%$ & $35.1 \%$ & $13.8 \%$ & $7.00 \%$ & $1.10 \%$ & $7.80 \%$ & $1.90 \%$ & $0.00 \%$ \\
\hline Tolal & 8,382 & $0.50 \%$ & $6.10 \%$ & $24.3 \%$ & $32.1 \%$ & $11.6 \%$ & $9.00 \%$ & $3.20 \%$ & $10.9 \%$ & $2.30 \%$ & $0.10 \%$ \\
\hline
\end{tabular}


Below, descriptive statistics on the model (4) variables for the (filtered) averages of the 1995-2000 period are presented. Annual data are reported in appendix 3 .

Table 4 Descriptive statistics of the averages of the five continuous variables included in model (4)

\begin{tabular}{|lccccccc|}
\hline Variable & FY+ & Mean & Median & St. d.* $^{*}$ & ${\text { Q3 }- \text { Q1 }^{\dagger}}^{\dagger}$ & Skewness & Kurtosis \\
\hline PTROE & 8,382 & 0.211 & 0.177 & 2.926 & 0.234 & 76.07 & 6.594 \\
PTTIE & 8,382 & 0.029 & 0.021 & 0.176 & 0.031 & 46.29 & 3,587 \\
R\&D & 8,382 & 0.002 & 0.000 & 0.014 & 0.000 & 12.03 & 209.9 \\
ME & 8,382 & 0.581 & 0.423 & 0.674 & 0.545 & 3.766 & 23.80 \\
PC & 8,382 & 0.309 & 0.261 & 0.263 & 0.246 & 3.222 & 18.11 \\
\hline
\end{tabular}

+ Firm-years; ${ }^{*}$ Standard deviation ; ${ }^{\dagger}$ Interquartile range

The R\&D variable shows a null value for the median. This is related to the recoding of this variable (see section 4.3.2). Table 4 also shows that the PTROE and PTTIE variables ${ }^{26}$ are characterized by a relatively large standard deviation. Closer examination of the data reveals a main cause of this finding: extreme observations ${ }^{27}$. The skewness and kurtosis statistics also indicate that the variables do not approximate the normal distribution. Below, the correlation between the variables is first examined using the Pearson correlation coefficient, the results of which are displayed in Table 5 .

Table 5 Pearson correlation coefficients (FY are 8,382)

\begin{tabular}{|lcclcl|}
\hline & PTTIE & PTROE & R\&D & ME & PC \\
\hline PTROE & $-0.923^{* *}$ & & & & \\
R\&D & 0.013 & 0.012 & & & \\
ME & $0.025^{*}$, & -0.009 & $-0.028^{*}$ & & \\
PC & $0.064^{* *}$ & $-0.039^{* *}$ & $0.058^{* *}$ & 0.003 & \\
STR & $-0.058^{* *}$ & -0.002 & $0.037^{* *}$ & $-0.049^{* *}$ & -0.012 \\
\hline
\end{tabular}

$*$ : significant at the $5 \%$ level

$* *$ : significant at the $1 \%$ level

The correlation coefficient for the PTROE-PTTIE relationship is high, with a value of -0.923 , compared to the expected (theoretical) value of -1 . This result provides support for a strong implicit taxes relationship among the companies in the sample. The Pearson correlation coefficients also indicate that the PTTIE and PC

\footnotetext{
${ }^{26}$ To test for a bias in data availability, the main model (1) relationship was tested for those companies reporting data only on model (1) variables and for those companies reporting data on all model (4) variables. The results of this analysis (reported in appendix 4) show no indications for such a bias.

${ }^{27}$ These extreme observations are partially caused by the nature of some of the variables: ratios. Ratios tend to produce extreme observations whenever the nominator or denominator approaches zero.
} 
variables in model (4) are significantly related to PTROE. They however also show that the independent variables are sometimes significantly but moderately correlated among themselves. Therefore, multicollinearity will not pose a serious problem here. Correlation analyses using the nonparametric Spearman rankcorrelation coefficient show mostly similar relationships between the variables, although some non-monotonous relationships between the variables seem to exist (especially with regard to the STR variable). These Spearman rank-correlation coefficients are reported in appendix 5 .

\subsubsection{Multivariate analysis}

The following general multivariate model, where the company subscript $i$ and time subscript $t$ are omitted, is used.

$$
\begin{aligned}
& \text { PTROE }_{i \mathrm{i}}=\alpha+\beta_{1} \text { PTTIE }+\beta_{2} \text { PTTIE }^{*} \text { R } \& D+\beta_{3} \text { R } \& D+\beta_{4} \text { PTTIE*ME }+\beta_{5} \text { ME } \\
& +\beta_{6} \text { PTTIE*PC }+\beta_{7} \text { PC }+\beta_{8} \text { PTTIE*STR }+\beta_{9} \text { STR }+\varepsilon
\end{aligned}
$$

An OLS regression analysis is used to estimate the multivariate model. Below, the results for the pooled firm-years sample model are reported ${ }^{28}$.

Table 6 OLS regression model test statistics (FY are 8,382)

\begin{tabular}{|lcccc|}
\hline Variable & Expected Sign & Coefficient & t-value $^{29}$ & Significance \\
\hline Intercept & & 0.109 & 3.221 & $0.001^{* *}$ \\
PTTIE & - & -3.266 & -133.0 & $0.000^{* *}$ \\
PTTIE*R\&D & + & 1.824 & 6.095 & $0.000^{* *}$ \\
R\&D & + & 1.250 & 3.003 & $0.003^{* *}$ \\
PTTIE*ME & - & -0.077 & -12.23 & $0.000^{* *}$ \\
ME & - & 0.007 & 0.793 & 0.428 \\
PTTIE*PC & - & -1.022 & -83.06 & $0.000^{* *}$ \\
PC & - & -0.609 & -26.25 & $0.000^{* *}$ \\
PTTIE*STR & $?$ & -6.593 & -116.9 & $0.000^{* *}$ \\
STR & $?$ & 0.578 & 7.088 & $0.000^{* *}$ \\
& & & & \\
$R$-square & (adj. R-square) & & 0.966 & $(0.966)$ \\
F-statistic & (p-value) & & 26,706 & $\left(0.000^{* *}\right)$ \\
\hline
\end{tabular}

$*$ : significant at the $5 \%$ level

**; significant at the $1 \%$ level

\footnotetext{
${ }_{29}^{28}$ Appendix 6 includes OLS regression model results for separate years.

29 The data show some first-order autocorrelation (not reported). In a similar setting, Fama and French (2000) adjust their t-values from 2.0 to 2.8 to infer reliability. As the appendices report annual results, such an adjustment is not made.
} 
The results indicate a very good overall fit of the model. The R-square of $96.6 \%$ compares favourably to those of Wilkie $(1992 ; 48 \%)$ and of Callihan and White $(1999 ; 24 \%)$, especially when taking into account differences between EU member states. The model itself is significant at the $1 \% \operatorname{level}^{30}$.

Overall, these results indicate the following. First, tax incentives are important in explaining pre-tax returns across the EU, i.e., they create implicit taxes. Second, focusing on the interaction variables, differences in product and factor market competition impact the implicit taxes relationship in a predictable way. And third, higher STRs strengthen the implicit taxes relationship.

In general, these results indicate that implicit taxes do have an impact on pretax returns with additional effects for the interaction variables involving $R \& D, M E$, PC, and STR. These and previous findings in this chapter might however be affected by theoretical and methodological issues. Therefore, the next paragraph provides sensitivity analyses addressing some of these issues.

\subsubsection{Sensitivity analyses}

Although the findings from the OLS regression model indicate a substantial implicit tax relationship across the EU countries, this finding might not hold for separate EU countries. To investigate the country level implicit tax relationships OLS regression models for EU countries with more than 300 firm-year observations are estimated. Belgium, Finland, France, Germany, Italy, The Netherlands, and the United Kingdom provide sufficient data on all variables ${ }^{31}$. The overall significance of the models as well as the t-values and significance of the different variables is reported in the Table below.

\footnotetext{
${ }^{30}$ Following Bowen et. al. (1995), a dummy variable indicating companies in the durable goods industry (SIC codes 150-179, 245, 250-259, 283, 301, 324-399) was also incorporated in the OLS regression model as a proxy for market power, which was also significant, but did not increase the explanatory power of the model. Results of this test are reported in appendix 7.

${ }^{31}$ Model 1 OLS regression results (not reported here) show significant PTTIE variables in all 15 EU-countries.
} 
Table 7 OLS régression model results for selected EU countries (Coefficients (t-values) for variables)

\begin{tabular}{|c|c|c|c|c|c|c|c|}
\hline Country & Belgium & Finland & France & Germany & Italy & Neth. & UK \\
\hline $\mathrm{FY}$ & 447 & 393 & 2,276 & 2,259 & 617 & 406 & 798 \\
\hline $\begin{array}{l}\text { F-value } \\
\text { (p-value) }\end{array}$ & $\begin{array}{r}799.4 \\
(0.000 * 0)\end{array}$ & $\begin{array}{r}701.7 \\
\left(0.000^{* *}\right)\end{array}$ & $\begin{array}{r}4,089 \\
\left(0.000^{* *}\right)\end{array}$ & $\begin{array}{r}415.5 \\
\left(0.000^{* 4}\right)\end{array}$ & $\begin{array}{r}2,120 \\
\left(0.000^{* *}\right)\end{array}$ & $\begin{array}{r}2,221 \\
\left(0.000^{* *}\right)\end{array}$ & $\begin{array}{r}10,709 \\
\left(0.000^{* *}\right)\end{array}$ \\
\hline Intercept & $\begin{array}{r}0.094 \\
\left(7.063^{* z}\right)\end{array}$ & $\begin{array}{r}0.064 \\
\left(6.507^{* *}\right)\end{array}$ & $\begin{array}{r}0.041 \\
(3.549 * *)\end{array}$ & $\begin{array}{r}-0.039 \\
(-1.300)\end{array}$ & $\begin{array}{r}-0.041 \\
\left(-2.551^{*}\right)\end{array}$ & $\begin{array}{r}-0.017 \\
\left(-2.119^{*}\right)\end{array}$ & $\begin{array}{r}-0.024 \\
\left(-2.235^{*}\right)\end{array}$ \\
\hline PTTIE & $\begin{array}{r}-1.210 \\
\left(-41.71^{*}\right)\end{array}$ & $\begin{array}{r}-1.721 \\
\left(-42.76^{* *}\right)\end{array}$ & $\begin{array}{r}-1.169 \\
\left(-74.17^{* *}\right)\end{array}$ & $\begin{array}{r}-0.363 \\
(-19.77 * *)\end{array}$ & $\begin{array}{r}-0.552 \\
\left(-18.28^{* *}\right)\end{array}$ & $\begin{array}{r}-0.959 \\
(-46.41 * *)\end{array}$ & $\begin{array}{r}-0.967 \\
\left(-127.1^{* * *}\right)\end{array}$ \\
\hline PTTIE*R\&D & N.A. & $\begin{array}{r}-0.516 \\
(-0.429)\end{array}$ & $\begin{array}{r}7.502 \\
(1.265)\end{array}$ & $\begin{array}{r}-1.538 \\
(-0.658)\end{array}$ & N.A. & $\begin{array}{r}1.018 \\
(0.823)\end{array}$ & $\begin{array}{r}1.734 \\
\left(7.953^{* *}\right)\end{array}$ \\
\hline R\&D & N.A. & $\begin{array}{r}0.141 \\
(0.263)\end{array}$ & $\begin{array}{r}2.370 \\
(1.444)\end{array}$ & $\begin{array}{r}0.033 \\
(0.031)\end{array}$ & N.A. & $\begin{array}{r}0.050 \\
(0.192)\end{array}$ & $\begin{array}{r}0.234 \\
(0.969)\end{array}$ \\
\hline PTTIE*ME & $\begin{array}{r}-0.074 \\
(-3.639 * * 1)\end{array}$ & $\begin{array}{r}0.169 \\
\left(4.912^{* *}\right)\end{array}$ & $\begin{array}{r}0.053 \\
(8.065 * *)\end{array}$ & $\begin{array}{r}-0.022 \\
(-1.817)\end{array}$ & $\begin{array}{r}-0.384 \\
\left(-26.89^{* *}\right)\end{array}$ & $\begin{array}{r}-0.030 \\
(-1.847)\end{array}$ & $\begin{array}{r}0.030 \\
\left(3.814^{* *}\right)\end{array}$ \\
\hline ME & $\begin{array}{r}-0.003 \\
(-0.343)\end{array}$ & $\begin{array}{r}0.030 \\
\left(4.518^{* *}\right)\end{array}$ & $\begin{array}{r}0.026 \\
\left(2.624^{* *}\right)\end{array}$ & $\begin{array}{r}0.010 \\
(0.485)\end{array}$ & $\begin{array}{r}-0.321 \\
\left(-14.93^{* *}\right)\end{array}$ & $\begin{array}{r}0.034 \\
(0.930)\end{array}$ & $\begin{array}{r}-0.017 \\
(-1.701)\end{array}$ \\
\hline PTTIE*PC & $\begin{array}{r}0.390 \\
(10.92 * *)\end{array}$ & $\begin{array}{r}0.519 \\
\left(4.836^{* * 4}\right)\end{array}$ & $\begin{array}{r}-0.452 \\
\left(-15.24^{* *}\right)\end{array}$ & $\begin{array}{r}-0.292 \\
\left(-9.947^{* *}\right)\end{array}$ & $\begin{array}{r}-0.194 \\
(-1.455)\end{array}$ & $\begin{array}{r}-0.034 \\
\left(-2.421^{*}\right)\end{array}$ & $\begin{array}{r}-0.369 \\
\left(-6.700^{* *}\right)\end{array}$ \\
\hline $\mathrm{PC}$ & $\begin{array}{r}0.009 \\
(0.198)\end{array}$ & $\begin{array}{r}0.025 \\
(0.826)\end{array}$ & $\begin{array}{r}-0.333 \\
\left(-13.46^{* *}\right)\end{array}$ & $\begin{array}{r}-0.228 \\
\left(-3.584^{* *}\right)\end{array}$ & $\begin{array}{r}0.072 \\
(0.765)\end{array}$ & $\begin{array}{r}-0.052 \\
\left(-3.309^{* *}\right)\end{array}$ & $\begin{array}{r}-0.086 \\
(-3.450 * *)\end{array}$ \\
\hline
\end{tabular}

*: significant at the $5 \%$ level

**: significant at the $1 \%$ level 
Again, the models are significant in all countries, with significance of the PTTIE variable in all countries. The results for the interaction variables are more mixed.

Analysis of the data sample distribution characteristics (for descriptive data, see appendix 3 ) indicates that the data are non-normally distributed. Both kurtosis and skewness are outside of a normal distribution type range. This can indicate that an OLS regression model is less suited to test for multivariate relationships in this setting. To take account of the particular distributional characteristics in this study, a rank regression model (RR) is used (also see chapter 3 ) to investigate the implicit tax relationship. The RR procedure assigns a proportion of the variance of the dependent variable to each unique value of the independent variables. The variables were divided in ten equal-sized groups to estimate the parameters. Due to the fact that each variable has ten different coefficients, no coefficients are included in Table 8 which reports the empirical results for the RR.

Table 8 RR model results (FY are 8,382)

\begin{tabular}{|lccl|}
\hline Variable & Expected sign & F-value & Significance \\
\hline Intercept & & 709.4 & $0.000^{* *}$ \\
PTTIE & - & $(-) 205.7$ & $0.000^{* *}$ \\
PTTIE*R\&D & + & 1.508 & 0.139 \\
R\&D & + & 1.483 & 0.148 \\
PTTIE*ME & - & $(-) 2.295$ & $0.014^{*}$ \\
ME & - & 2.452 & $0.009^{* *}$ \\
PTTIE*PC & - & $(-) 3.394$ & $0.000^{* *}$ \\
PC & - & $(-) 6.769$ & $0.000^{* *}$ \\
PTTIE*STR & $?$ & $(-) 38.62$ & $0.000^{* *}$ \\
STR & $?$ & 93.09 & $0.000^{* *}$ \\
& ? & & \\
R-square & (adj. R-square) & 0.874 & $(0.873)$ \\
F-statistic & (p-value) & 743.9 & $\left(0.000^{* *}\right.$ ) \\
\hline
\end{tabular}

*: significant at the $5 \%$ level

**: significant at the $1 \%$ level

$(-)$ : indicates a negative relationship between this variable and ETRI/2 in the RR model.

Overall, the OLS regression results are comparable with the rank regression model results regarding the explanatory power of the model. That is, the implicit taxes relationship is again quite strong for the examined companies. For the individual variables, the results are as follows: The PTTIE and the interaction variable coefficients are in general significant with the predicted sign.

Erickson and Maydew (1998) indicate a possible effect of company size on implicit taxes. To investigate this possible effect, model (5) was specified with average total assets as an additional variable. Results for this analysis (see appendix 8 ) show that company size has no influence on the findings reported above.

Part of the results of the analyses could be driven by incidental observations. 
To take such incidental observations into account, a balanced panel is constructed for the years $1995-2000^{32}$. The balanced panel consists of 3,852 firm-year observations. Again, an OLS regression model was estimated for this balanced panel, the results of which are reported in appendix 9 . The results of the balanced panel show weaker results for two of the interaction variables.

\subsection{Conclusion}

Countries and their tax authorities impose corporate income taxes on companies. To guide the economic activities of these agents, governments provide certain tax incentives. The level of tax incentives between countries and companies differs, influencing the effective level of taxation. These differences in effective taxation would lead to differences in after-tax returns if companies were not traded in competitive markets. The existence of such markets should lead to equal riskadjusted after-tax returns. Differences in effective taxation must thus lead to differences in pre-tax returns by means of arbitrage.

Prior research has confirmed the existence of the implicit tax relationship between tax incentives and pre-tax returns. However, this research indicated that controls for market imperfections are necessary to capture the full implicit tax effect. This chapter provides a more comprehensive framework to capture such imperfections in product and factor markets. Also, this chapter is the first to investigate implicit taxes in the European context, assessing the implicit tax relationship across all EU-countries.

Statistical results provide strong support for the existence of the implicit tax relationships across the European Union member states. The statistical results also provide support for the proxies designed to capture differences in product- and factor market differences. These are also statistically significant in explaining pretax income levels. Finally, the level of tax rates systematically affects results across countries, indicating that higher levels of statutory tax rates strengthen the implicit taxes relationship.

\footnotetext{
${ }^{32}$ A balanced panel only includes companies reporting all data for all years, thus excluding companies, which do not report data for all years.
} 


\section{appendices}

1 R\&D variable: the effect of recoding

Descriptive statistics for recoded R\&D and not-recoded R\&D

\begin{tabular}{|lcc|}
\hline Statistic & recoded R\&D & R\&D (not-recoded) \\
\hline Mean & 0.002 & 0.004 \\
Standard deviation & 0.014 & 0.048 \\
Median & 0.000 & 0.016 \\
Interquartile range & 0.000 & 0.040 \\
Firm-years & 8,382 & 499 \\
\hline
\end{tabular}

For variable definitions see section 4.3.2. 


\section{Pooled sample}

Descriptive statistics of the filtered pooled sample for 1995-2000

\begin{tabular}{|lrrrrrrr|}
\hline Variable & \multicolumn{1}{l}{ FY } & Mean & Median & $\begin{array}{l}\text { Std. } \\
\text { dev. }{ }^{*}\end{array}$ & Q3 - Q1 $^{\dagger}$ & Skewness & Kurtosis \\
\hline PTROE & 24,209 & 0.158 & 0.162 & 3.576 & 0.263 & 58.37 & 10,008 \\
PTTIE & 23,256 & 0.022 & 0.016 & 0.230 & 0.028 & 28.36 & 3,628 \\
R\&D & 3,843 & 0.081 & 0.034 & 0.140 & 0.086 & 6.491 & 79.90 \\
ME & 8,687 & 0.580 & 0.422 & 0.675 & 0.548 & 3.731 & 23.29 \\
PC & 11,432 & 0.306 & 0.244 & 0.299 & 0.262 & 3.251 & 18.05 \\
\hline
\end{tabular}

Descriptive statistics of the filtered pooled sample for 1995-2000 with only Firm-Years with all variables available ( $R \& D$ variable not recoded)

\begin{tabular}{|lrrrrrrr|}
\hline Variable & \multicolumn{1}{l}{ FY } & Mean & Median & $\begin{array}{l}\text { Std. } \\
\text { dev. }\end{array}$ & Q3 - Q1 $^{\dagger}$ & Skewness & Kurtosis \\
\hline PTROE & 8,382 & 0.211 & 0.177 & 2.926 & 0.234 & 76.07 & 6,594 \\
PTTIE & 8,382 & 0.029 & 0.021 & 0.176 & 0.031 & 46.29 & 3,587 \\
R\&D & 499 & 0.004 & 0.016 & 0.048 & 0.040 & 3.036 & 14.45 \\
ME & 8,382 & 0.581 & 0.423 & 0.674 & 0.545 & 3.766 & 23.80 \\
PC & 8,382 & 0.309 & 0.261 & 0.263 & 0.246 & 3.222 & 18.11 \\
\hline
\end{tabular}

Descriptive statistics of the unfiltered pooled sample for 1995-2000

\begin{tabular}{|lrrrrrrr|}
\hline Variable & \multicolumn{1}{l}{ FY } & Mean & Median & $\begin{array}{l}\text { Std. } \\
\text { dev. }{ }^{*}\end{array}$ & $\begin{array}{l}\text { Q3 - } \\
\text { Q1 }^{\dagger}\end{array}$ & Skewness & Kurtosis \\
\hline PTROE & 24,319 & 0.553 & 0.162 & 114.1 & 0.265 & 151.6 & 23,408 \\
PTTIE & 23,350 & 0.036 & 0.016 & 9.648 & 0.028 & 143.2 & 21,373 \\
R\&D & 3,843 & 0.081 & 0.034 & 0.140 & 0.086 & 6.491 & 79.90 \\
ME & 8,687 & 0.580 & 0.422 & 0.675 & 0.548 & 3.731 & 23.29 \\
PC & 11,432 & 0.306 & 0.244 & 0.299 & 0.262 & 3.251 & 18.05 \\
\hline
\end{tabular}

For variable definitions see section 4.3 .2 .

* Standard deviation ; ${ }^{\dagger}$ Interquartile range 
Descriptive statistics of the five variables included in model (4) for 1995 (FY are 928)

\begin{tabular}{|lrrlccc|}
\hline Variable & \multicolumn{1}{c}{ Mean } & Median & Std. dev.* $^{*}$ & Q3 $^{-\mathbf{Q 1}^{\dagger}}$ & Skewness & Kurtosis \\
\hline PTROE & 0.162 & 0.165 & 0.310 & 0.199 & 1.038 & 30.53 \\
PTTIE & 0.023 & 0.019 & 0.036 & 0.025 & 1.363 & 13.11 \\
R\&D & 0.003 & 0.000 & 0.017 & 0.000 & 8.315 & 81.54 \\
ME & 0.599 & 0.467 & 0.651 & 0.534 & 3.833 & 24.09 \\
PC & 0.301 & 0.264 & 0.234 & 0.237 & 3.300 & 20.63 \\
\hline
\end{tabular}

Descriptive statistics of the five variables included in model (4) for 1996 (FY are 1,087)

\begin{tabular}{|lrrcccc|}
\hline Variable & Mean & Median & Std. dev. $^{*}$ & Q3-Q1 $^{\dagger}$ & Skewness & Kurtosis \\
\hline PTROE & 0.179 & 0.172 & 0.369 & 0.210 & 0.109 & 27.60 \\
PTTIE & 0.025 & 0.020 & 0.046 & 0.027 & 1.155 & 15.70 \\
R\&D & 0.003 & 0.000 & 0.017 & 0.000 & 8.408 & 85.02 \\
ME & 0.604 & 0.448 & 0.656 & 0.514 & 3.114 & 14.42 \\
PC & 0.309 & 0.268 & 0.249 & 0.241 & 3.164 & 17.37 \\
\hline
\end{tabular}

Descriptive statistics of the five variables included in model (4) for 1997 (FY are 1,299)

\begin{tabular}{|lrrrrrc|}
\hline Variable & Mean & Median & Std. dev. $^{*}$ & ${\text { Q3 }-\mathbf{Q 1}^{+}}^{{ }^{+}}$ & Skewness & Kurtosis \\
\hline PTROE & 0.232 & 0.189 & 0.745 & 0.216 & 3.109 & 126.4 \\
PTTIE & 0.032 & 0.023 & 0.079 & 0.031 & 0.107 & 50.80 \\
R\&D & 0.003 & 0.000 & 0.018 & 0.000 & 11.02 & 161.8 \\
ME & 0.603 & 0.443 & 0.666 & 0.569 & 3.026 & 13.82 \\
PC & 0.317 & 0.270 & 0.275 & 0.247 & 3.189 & 16.58 \\
\hline
\end{tabular}

Descriptive statistics of the five variables included in model (4) for 1998 (FY are 1,630)

\begin{tabular}{|lcrlcrc|}
\hline Variable & Mean & Median & Std. dev.* $^{*}$ & Q3- Q1 $^{\dagger}$ & Skewness & Kurtosis \\
\hline PTROE & 0.223 & 0.191 & 1.305 & 0.247 & 25.85 & 933.1 \\
PTTIE & 0.034 & 0.023 & 0.143 & 0.035 & 18.29 & 641.5 \\
R\&D & 0.002 & 0.000 & 0.012 & 0.000 & 7.911 & 69.73 \\
ME & 0.609 & 0.435 & 0.714 & 0.575 & 3.465 & 19.07 \\
PC & 0.321 & 0.268 & 0.287 & 0.255 & 3.306 & 18.07 \\
\hline
\end{tabular}

Descriptive statistics of the five variables included in model (4) for 1999 (FY are 1,829)

\begin{tabular}{|lccccrc|}
\hline Variable & Mean & \multicolumn{1}{c}{ Median } & Std. dev. $^{*}$ & Q3-Q1 $^{\dagger}$ & Skewness & Kurtosis \\
\hline PTROE & 0.308 & 0.179 & 6.155 & 0.263 & 37.46 & 1.543 \\
PTTIE & 0.035 & 0.022 & 0.354 & 0.036 & 26.24 & 1,007 \\
R\&D & 0.001 & 0.000 & 0.009 & 0.000 & 9.328 & 107.7 \\
ME & 0.558 & 0.389 & 0.699 & 0.542 & 4.476 & 33.16 \\
PC & 0.309 & 0.254 & 0.269 & 0.245 & 3.249 & 18.70 \\
\hline
\end{tabular}


Descriptive statistics of the five variables included in model (4) for 2000 (FY are 1,684)

\begin{tabular}{|lcccccc|}
\hline Variable & \multicolumn{1}{c}{ Mean } & Median & Std. dev. $^{*}$ & Q3- Q1 $^{\dagger}$ & Skewness & Kurtosis \\
\hline PTROE & 0.099 & 0.151 & 0.706 & 0.260 & 6.400 & 86.73 \\
PTTIE & 0.018 & 0.017 & 0.057 & 0.030 & 3.404 & 70.56 \\
R\&D & 0.001 & 0.000 & 0.014 & 0.000 & 21.08 & 567.2 \\
ME & 0.539 & 0.377 & 0.649 & 0.553 & 4.103 & 29.58 \\
PC & 0.291 & 0.245 & 0.245 & 0.251 & 2.844 & 15.13 \\
\hline
\end{tabular}

For variable definitions see section 4.3.2.

* Standard deviation ; ${ }^{+}$Interquartile range 
4 Model (1) OLS regression for companies reporting data on model (1) variables and companies reporting data on all model (4) variables

Model (1) OLS regression results for companies reporting data on model (1) variables

\begin{tabular}{|c|c|c|c|c|c|}
\hline Variable & & FY & Coefficient & t-value & Significance \\
\hline Intercept & & 22,895 & 0.160 & 14.53 & $0.000^{* *}$ \\
\hline PTTIE & & 22,895 & -1.497 & -294.3 & $0.000 * *$ \\
\hline $\begin{array}{l}R \text {-square } \\
\text { F-statistic }\end{array}$ & $\begin{array}{l}\text { (adj. R-square) } \\
\text { (p-value) }\end{array}$ & & & $\begin{array}{r}0.791 \\
86,632 \\
\end{array}$ & $\begin{array}{l}(0.791) \\
\left(0.000^{* *}\right)\end{array}$ \\
\hline
\end{tabular}

Model (1) OLS regression results for companies reporting data on all model (4) variables

\begin{tabular}{|c|c|c|c|c|c|}
\hline Variable & & FY & Coefficient & t-value & Significance \\
\hline Intercept & & 8,382 & 0.233 & 18.70 & $0.000^{* *}$ \\
\hline PTTIE & & 8,382 & -1.533 & -220.1 & $0.000^{* *}$ \\
\hline $\begin{array}{l}R \text {-square } \\
\text { F-statistic }\end{array}$ & $\begin{array}{l}\text { (adj. } R \text {-square) } \\
\text { (p-value) }\end{array}$ & & & $\begin{array}{r}0.852 \\
48,430 \\
\end{array}$ & $\begin{array}{l}(0.852) \\
\left(0.000^{* *}\right)\end{array}$ \\
\hline
\end{tabular}

For variable definitions see section 4.3.2.

* : significant at the $5 \%$ level

**: significant at the $1 \%$ level 


\section{Spearman correlation}

Spearman rank-correlation coefficients (FY are 8,382)

\begin{tabular}{|lccccc|}
\hline Variables & PTTIE & PTROE & R\&D & ME & PC \\
\hline PTROE & $-0.926^{* *}$ & & & & \\
R\&D & 0.019 & -0.012 & & & \\
ME & $0.088^{* *}$ & $-0.082^{* *}$ & -0.021 & & \\
PC & $0.129^{* *}$ & $-0.125^{* *}$ & 0.004 & $0.253^{* *}$ & \\
STR & $-0.213^{* *}$ & -0.005 & $0.189^{* *}$ & $-0.029^{* *}$ & -0.012 \\
\hline
\end{tabular}

For variable definitions see section 4.3 .2 ,

*: significant at 5 percent level

**: significant at 1 percent level 


\section{Separate year OLS regression results}

1995 OLS regression results (FY are 916)

\begin{tabular}{|lcrcc|}
\hline \multicolumn{1}{|c}{ Variable } & Expected sign & Coefficient & t-value & Significance \\
\hline Intercept & & 0.007 & 0.263 & 0.793 \\
PTTIE & - & -2.295 & -28.70 & $0.000^{* *}$ \\
PTTIE*R\&D & + & 1.054 & 0.905 & 0.366 \\
R\&D & + & 0.113 & 0.271 & 0.787 \\
PTTIE*ME & - & -0.020 & -0.919 & 0.358 \\
ME & - & -0.001 & -0.005 & 0.996 \\
PTTIE*PC & - & -0.028 & -0.663 & 0.508 \\
PC & - & -0.051 & -1.983 & $0.048^{*}$ \\
PTTIE*STR & $?$ & -3.345 & -20.67 & $0.000^{* *}$ \\
STR & $?$ & -0.051 & -0.806 & 0.421 \\
& & & & \\
$R$-square & (adj. $R$-square) & & 0.788 & $(0.786)$ \\
F-statistic & (p-value) & & 379.5 & $\left(0.000^{* *}\right)$ \\
\hline
\end{tabular}

1996 OLS regression results (FY are 1,075)

\begin{tabular}{|lcrcc|}
\hline \multicolumn{1}{|c}{ Variable } & Expected sign & Coefficient & t-value & Significance \\
\hline Intercept & & -0.091 & -3.436 & $0.001^{* *}$ \\
PTTIE & - & -2.104 & -31.14 & $0.000^{* *}$ \\
PTTIE*R\&D & + & -3.457 & -7.572 & $0.000^{* *}$ \\
R\&D & + & -0.737 & -2.708 & $0.007^{* *}$ \\
PTTIE*ME & - & 0.021 & 2.613 & $0.009^{* *}$ \\
ME & - & 0.011 & 1.504 & 0.133 \\
PTTIE*PC & - & -0.028 & -1.104 & 0.270 \\
PC & - & -0.055 & -2.818 & $0.005^{* *}$ \\
PTTIE*STR & $?$ & -2.924 & -21.07 & $0.000^{* *}$ \\
STR & $?$ & -0.294 & -4.648 & $0.000^{* *}$ \\
& & & & \\
R-square & (adj. $R$-square) & & 0.858 & $(0.856)$ \\
$F$-statistic & (p-value) & & 720.6 & $\left(0.000^{* *}\right)$ \\
\hline
\end{tabular}


1997 OLS regression results (FY are 1,287)

\begin{tabular}{|lcccc|}
\hline \multicolumn{1}{|c}{ Variable } & Expected sign & Coefficient & t-value & Significance \\
\hline Intercept & & -0.013 & -0.255 & 0.799 \\
PTTIE & - & -2.477 & -36.21 & $0.000^{* *}$ \\
PTTIE*R\&D & + & 1.499 & 0.607 & 0.544 \\
R\&D & + & 0.689 & 0.705 & 0.481 \\
PTTIE*ME & - & 0.053 & 5.391 & $0.000^{* *}$ \\
ME & - & 0.033 & 2.186 & $0.029^{*}$ \\
PTTIE*PC & - & -0.129 & -6.312 & $0.000^{* *}$ \\
PC & - & -0.179 & -4.724 & $0.000^{* *}$ \\
PTTIE*STR & $?$ & -3.787 & -24.74 & $0.000^{* *}$ \\
STR & $?$ & -0.036 & -0.287 & 0.774 \\
& & & & \\
$R$-square & (adj. $R$-square) & & 0.792 & $(0.791)$ \\
$F$-statistic & (p-value) & & 545.4 & $\left(0.000^{* *}\right)$ \\
\hline
\end{tabular}

1998 OLS regression results (FY are 1,617)

\begin{tabular}{|lcrcc|}
\hline \multicolumn{1}{|c}{ Variable } & Expected sign & Coefficient & t-value & Significance \\
\hline Intercept & & -0.122 & -3.360 & $0.001^{* *}$ \\
PTTIE & - & -1.637 & -79.04 & $0.000^{* *}$ \\
PTTIE*R\&D & + & 13.19 & 8.954 & $0.000^{* *}$ \\
R\&D & + & 4.131 & 7.068 & $0.000^{* *}$ \\
PTTIE*ME & - & 0.002 & 0.323 & 0.747 \\
ME & - & -0.007 & -0.700 & 0.484 \\
PTTIE*PC & - & 0.028 & 1.598 & 0.110 \\
PC & - & -0.029 & -1.199 & 0.231 \\
PTTIE*STR & $?$ & -1.989 & -32.10 & $0.000^{* *}$ \\
STR & $?$ & -0.332 & -3.803 & $0.000^{* *}$ \\
& & & & \\
R-square & (adj. $R$-square) & & 0.965 & $(0.965)$ \\
F-statistic & (p-value) & & 4,971 & $\left(0.000^{* *}\right)$ \\
\hline
\end{tabular}


1999 OLS regression results (FY are 1,816)

\begin{tabular}{|lcccl|}
\hline \multicolumn{1}{|c}{ Variable } & Expected sign & Coefficient & t-value & Significance \\
\hline Intercept & & 0.256 & 2.115 & $0.035^{*}$ \\
PTTIE & - & -4.363 & -38.61 & $0.000^{* *}$ \\
PTTIE*R\&D & + & 5.256 & 0.659 & 0.510 \\
R\&D & + & 2.326 & 0.975 & 0.330 \\
PTTIE*ME & - & -0.076 & -5.182 & $0.000^{* *}$ \\
ME & - & 0.028 & 1.051 & 0.293 \\
PTTIE*PC & - & -0.703 & -12.43 & $0.000^{* *}$ \\
PC & - & -0.382 & -5.289 & $0.000^{* *}$ \\
PTTIE*STR & $?$ & -8.925 & -44.75 & $0.000^{* *}$ \\
STR & $?$ & 0.698 & 2.406 & $0.016^{*}$ \\
& & & & \\
$R$-square & (adj. $R$-square) & & 0.984 & $(0.984)$ \\
F-statistic & (p-value) & & 1.259 & $\left(0.000^{* *}\right.$ ) \\
\hline
\end{tabular}

\section{OLS regression results (FY are 1,671)}

\begin{tabular}{|lcccl|}
\hline \multicolumn{1}{|c}{ Variable } & Expected sign & Coefficient & t-value & Significance \\
\hline Intercept & & 0.113 & 2.855 & $0.004^{* *}$ \\
PTTIE & - & -3.381 & -43.40 & $0.000^{* *}$ \\
PTTIE*R\&D & + & -0.131 & -0.504 & 0.614 \\
R\&D & + & 0.712 & 1.137 & 0.256 \\
PTTIE*ME & - & 0.059 & 4.472 & $0.000^{* *}$ \\
ME & - & 0.030 & 3.045 & $0.002^{* *}$ \\
PTTIE*PC & - & -0.375 & -7.734 & $0.000^{* *}$ \\
PC & - & 0.203 & 7.257 & $0.000^{* *}$ \\
PTTIE*STR & $?$ & -5.715 & -31.14 & $0.000^{* *}$ \\
STR & $?$ & 0.126 & 1.279 & 0.201 \\
& & & & \\
R-square & (adj. $R$-square) & & 0.884 & $(0.883)$ \\
F-statistic & (p-value) & & 1.417 & $\left(0.000^{* *}\right)$ \\
\hline
\end{tabular}

For variable definitions see section 4.3.2.

$*$ : significant at the $5 \%$ level

**: significant at the $1 \%$ level 


\section{OLS regression with durable goods dummy}

OLS regression results for model (5) with durable goods dummy (FY are 8,382)

\begin{tabular}{|lccrc|}
\hline Variable & Expected sign & Coefficient & t-value & Significance \\
\hline Intercept & & 0.117 & 3.469 & $0.001^{* *}$ \\
PTTIE & - & -3.262 & -132.9 & $0.000^{* *}$ \\
PTTIE*R\&D & + & 1.893 & 6.328 & $0.000^{* *}$ \\
R\&D & + & 1.056 & 2.529 & $0.011^{* *}$ \\
PTTIE*ME & - & -0.077 & -12.28 & $0.000^{* *}$ \\
ME & - & 0.007 & 0.815 & 0.415 \\
PTTIE*PC & - & -1.024 & -83.28 & $0.000^{* *}$ \\
PC & - & -0.616 & -26.53 & $0.000^{* *}$ \\
PTTIE*STR & $?$ & -6.584 & -116.9 & $0.000^{* *}$ \\
STR & $?$ & 0.552 & 6.768 & $0.000^{* *}$ \\
Durable goods & + & 0.060 & 4.812 & $0.000^{* *}$ \\
& & & & \\
$R$-square & (adj. $R$-square) & & 0.966 & $(0.966)$ \\
$F$-statistic & (p-value) & & 24.101 & $\left(0.000^{* *}\right)$ \\
\hline
\end{tabular}

For variable definitions see section 4.3.2.

$*$ : significant at the $10 \%$ level

**: significant at the $1 \%$ level 


\section{OLS regression with average total assets}

OLS regression results for model (5) with average total assets (FY are 8,382)

\begin{tabular}{|lccrc|}
\hline Variable & Expected sign & Coefficient & t-value & Significance \\
\hline Intercept & & 0.110 & 3.259 & $0.001^{* *}$ \\
PTTIE & - & -3.266 & -133.0 & $0.000^{* *}$ \\
PTTIE*R\&D & + & 1.823 & 6.094 & $0.000^{* *}$ \\
R\&D & + & 1.253 & 3.011 & $0.003^{* *}$ \\
PTTIE*ME & - & -0.077 & -12.22 & $0.000^{* *}$ \\
ME & - & 0.007 & 0.812 & 0.417 \\
PTTIE*PC & - & -1.022 & -83.07 & $0.000^{* *}$ \\
PC & - & -0.609 & -26.25 & $0.000^{* *}$ \\
PTTIE*STR & $?$ & -6.593 & -117.0 & $0.000^{* *}$ \\
STR & $?$ & 0.578 & 7.091 & $0.000^{* *}$ \\
Total assets & $?$ & 0.001 & 0.924 & 0.356 \\
& & & & \\
$R$-square & (adj. R-square) & & 0.966 & $(0.966)$ \\
F-statistic & (p-value) & & 24,035 & $\left(0.000^{* *}\right)$ \\
\hline
\end{tabular}

For variable definitions see section 4.3.2.

$*$ : significant at the $5 \%$ level

**: significant at the $1 \%$ level 


\section{OLS regression results for balanced panel}

OLS regression model test statistics balanced panel 1995-2000 (FY are 3,852)

\begin{tabular}{|lcccc|}
\hline Variable & Expected sign & Coefficient & t-value & Significance \\
\hline Intercept & & 0.021 & 1.211 & 0.226 \\
PTTIE & - & -2.340 & -56.89 & $0.000^{* *}$ \\
PTTIE*R\&D & + & 0.277 & 0.303 & 0.762 \\
R\&D & + & 0.173 & 0.512 & 0.609 \\
PTTIE*ME & - & -0.074 & -12.16 & $0.000^{* *}$ \\
ME & - & 0.024 & 5.549 & $0.000^{* *}$ \\
PTTIE*PC & - & -0.003 & -0.143 & 0.887 \\
PC & - & -0.055 & -3.745 & $0.000^{* *}$ \\
PTTIE*STR & $?$ & -3.340 & -37.67 & $0.000^{* *}$ \\
STR & $?$ & 0.053 & 1.267 & 0.205 \\
& & & & \\
$R$-square & (adj. R-square) & & 0.826 & $(0.826)$ \\
F-statistic & (p-value) & & 2,025 & $\left(0.000^{* *}\right)$ \\
\hline
\end{tabular}

For variable definitions see section 4.3.2.

* : significant at the $5 \%$ level

**: significant at the $1 \%$ level 


\section{chapter 5}

\section{Conclusion}

\subsection{Introduction}

This dissertation has examined (determinants of) explicit and implicit corporate tax burdens in the Netherlands and the European Union. Three empirical studies have been carried out to examine the three research questions. Finally, this chapter will (i) provide a summary of this dissertation, (ii) discuss the use of financial statement data, (iii) list the strengths and weaknesses of the empirical studies, (iv) provide a conclusion and implications, and (v) indicate directions for future research.

\subsection{Summary}

Chapter 1, the introduction, characterizes research on corporate income taxes. This overview shows that the empirical research in the three subsequent chapters can be characterized as corporate tax burden research in the tax planning domain of the business subfield of corporate income tax research. The measurement of the corporate tax burden can best be described as empirical micro backward looking using average tax rates.

Included in this dissertation are three empirical studies. The first empirical study, in chapter 2 , assessed between-country differences in corporate tax burdens within the European Union. To assess these corporate tax burdens, the average effective tax rate (ETR) measure, based on financial statement data, was used. Both the absolute level of ETRs as well as the difference between ETR and statutory tax rates (STR) were examined, to be able to measure the level of tax incentives provided to companies. Using the Worldscope CD-ROM database to collect the sample, the reported ETRs showed considerable variations 
between and within countries. As European Union member states use different financial accounting conventions, three different ETRs were specified. To take the considerable variations in reported ETRs into account, the sample was filtered by removing all observations being more than two standard deviations from the mean of ETR1. In Table 1, STRs and median ETRs for the European Union member states are reported.

Table 1 STRs and median ETR1s as reported in chapter 2

\begin{tabular}{|lcccc|}
\hline Country & companies & w. avg. ETR1 & median ETR1 & STR - ETR \\
\hline Austria & 39 & 36.02 & 17.67 & 18.35 \\
Belgium & 50 & 40.28 & 20.99 & 19.29 \\
Denmark & 101 & 35.78 & 29.40 & 6.38 \\
Finland & 69 & 34.02 & 29.82 & 4.20 \\
France & 289 & 34.70 & 32.82 & 1.88 \\
Germany & 319 & 50.05 & 38.53 & 11.52 \\
Greece & 5 & 32.53 & 20.85 & 11.68 \\
Ireland & 40 & 21.94 & 13.86 & 8.08 \\
Italy & 27 & 50.48 & 35.32 & 15.16 \\
Luxembourg & 5 & 39.40 & 34.09 & 5.31 \\
Netherlands & 123 & 35.00 & 31.80 & 3.20 \\
Portugal & 32 & 39.29 & 17.19 & 22.10 \\
Spain & 84 & 35.30 & 24.11 & 11.19 \\
Sweden & 103 & 28.54 & 27.47 & 1.07 \\
UK & 832 & 33.35 & 29.00 & 4.35 \\
\hline
\end{tabular}

For variable definitions, see chapter 2 .

While some countries report only a small STR/ETR difference, other countries have a large difference of up to about 20 percentage points. These results might (partially) be driven by differences in financial accounting conventions, so two alternative ETR definitions were also specified. In general, these alternative ETR definitions produced comparable rankings. Such results support the conclusion that the provision of tax incentives differs substantially between countries and that these tax incentives do not lead to an equalization of ETRs across countries in the European Union.

Earlier research (for an overview, see Callihan 1994 and Shackelford and Shevlin 2001) has shown that ETRs differ within countries. This can be an indication that similar firms do not pay similar taxes. Thus, chapter 3 investigates factors affecting corporate tax burdens in the Netherlands, to determine whether the ETR distributions can be characterized by particular sample attributes. To investigate the research question, a sample from the $R E A C H$ CD-ROM database was retrieved containing 1,592 companies. Two ETR measures were estimated, ETR1 based on earnings, and ETR2 based on cash flows. To control for extreme observations, all ETR observations being more than two standard deviations from the mean were deleted. Based on 
previous empirical studies and the specific attributes of the Dutch corporate income tax system, six variables were specified (excluding control and interaction variables). OLS regression and rank regression (RR) model specifications were used to test the influence of these variables on reported ETRs. Table 2 provides statistical results for both model specifications.

Table 2 OLS regression and rank regression test statistics for determinants of ETRs

\begin{tabular}{|c|c|c|c|c|c|}
\hline ETR measure & & ETR1 & & ETR2 & \\
\hline Variable & Model & $t$-/F-value & Significance & $t$-/F-value & Significance \\
\hline \multirow[t]{2}{*}{ Intercept } & OLS & 11.08 & $0.000^{* *}$ & 5.492 & $0.000^{* *}$ \\
\hline & $\mathbf{R} \mathbf{R}$ & 2,114 & $0.000^{* *}$ & 2,806 & $0.000^{* *}$ \\
\hline \multirow[t]{2}{*}{ Firm size } & OLS & -2.937 & $0.003^{* *}$ & -0.606 & 0.545 \\
\hline & RR & $(-) 2.668$ & $0.004^{* *}$ & (-) 2.386 & $0.011^{*}$ \\
\hline \multirow[t]{2}{*}{ Capital intensity } & OLS & -5.156 & $0.000^{* *}$ & -10.58 & $0.000^{* *}$ \\
\hline & RR & $(-) 3.980$ & $0.000^{* *}$ & $(-) 33.15$ & $0.000^{* *}$ \\
\hline \multirow[t]{2}{*}{ Foreign sales } & OLS & 1.203 & 0.229 & 1.824 & 0.068 \\
\hline & RR & $(-) 1.096$ & 0.362 & 2.318 & $0.013^{*}$ \\
\hline \multirow[t]{2}{*}{ Return on assets } & OLS & -0.068 & 0.946 & 9.952 & $0.000^{* *}$ \\
\hline & RR & 2.355 & $0.016^{*}$ & 92.20 & $0.000 * *$ \\
\hline \multirow[t]{2}{*}{ Leverage } & OLS & 2.880 & $0.004 * *$ & 6.170 & $0.000^{* *}$ \\
\hline & RR & 3.175 & $0.001 * *$ & 11.77 & $0.000^{* *}$ \\
\hline \multirow[t]{2}{*}{ Public company } & OLS & -0.659 & 0.510 & -1.483 & 0.138 \\
\hline & RR & $(-) 11.80$ & $0.001^{* *}$ & 11.77 & $0.000^{* * *}$ \\
\hline \multirow[t]{2}{*}{$R$-square } & OLS & 0.011 & $\begin{array}{c}0.009 \\
\text { (adjusted) }\end{array}$ & 0.059 & $\begin{array}{r}0.058 \\
\text { (adjusted) }\end{array}$ \\
\hline & $R R$ & 0.041 & $\begin{array}{l}0.031 \\
\text { (adjusted) }\end{array}$ & 0.251 & $\begin{array}{r}0.242 \\
\text { (adjusted) }\end{array}$ \\
\hline \multirow[t]{2}{*}{$F$-statistic } & OLS & 7.370 & $\begin{array}{c}0.000 * * \\
\text { (p-value) }\end{array}$ & 39.82 & $\begin{array}{c}0.000 * * \\
\text { (p-value) }\end{array}$ \\
\hline & $R R$ & 3.877 & $\begin{array}{c}0.000 * * \\
\text { (p-value) }\end{array}$ & 28.03 & $\begin{array}{l}0.000^{* *} \\
\text { (p-value) }\end{array}$ \\
\hline
\end{tabular}

For variable definitions, see chapter 3.

*: Significant at the $5 \%$-level

**: Significant at the $1 \%$-level

The OLS regression and RR results indicate that the capital intensity (CAPINT) and leverage (LEV) variables are significant in both the ETR1 and ETR2 models. However, the explanatory power of these variables and the model in general tends to be very low. These results, combined with the finding of a relatively small difference between STR and ETR, indicate that, for the examined variables, the levying of corporate income taxes in the Netherlands is fairly neutral. However, as far as these results (and the OLS regression results) might be driven by methodological issues, sensitivity analyses were performed for the following factors: 
- Control variables;

- Balanced panel data;

- Deferred taxes;

- Industry effects.

The results of the sensitivity analyses do not contradict the findings of the OLS regression and RR models. That is, for the examined company attributes, Dutch corporate income taxation is fairly neutral with the noted exception of capital intensity and leverage being negatively associated with ETRs.

In the last empirical chapter, chapter 4, the implicit taxes framework, developed by Scholes and Wolfson (1992), is tested in the European Union corporate setting. The rationale behind the implicit taxes framework is that tax incentives lower taxes payable, thereby increasing after-tax returns. This will enable tax arbitrage which, in its turn, will drive up the demand for such investments, thereby lowering the pre-tax returns. The differences in pre-tax returns of normally taxed investments and lower taxed investments are called implicit taxes. Scholes \& Wolfson (1992), however, also indicate that this implicit taxes relationship can only fully work in a setting without risk differences and tax arbitrage inhibiting factors. The study in chapter 4 controls both for risk differences (by the design of the empirical model) and tax arbitrage inhibiting factors (by including three additional variables) in the model. Based on an Osiris sample the OLS regression and RR models showed the following results:

Table 3 OLS regression and RR test statistics for the implicit taxes framework

\begin{tabular}{|c|c|c|c|c|c|}
\hline Model & OLS & & & RR & . \\
\hline Variable & Coeff. & t-value & Significance & F-value & Significance \\
\hline Intercept & 0.109 & 3.221 & $0.001^{* *}$ & 709.4 & $0.000^{* *}$ \\
\hline PTTIE & -3.266 & -133.0 & $0.000^{* *}$ & (-) 205.7 & $0.000^{* *}$ \\
\hline PTTIE*R\&D & 1.824 & 6.095 & $0.000^{* *}$ & 1.508 & 0.139 \\
\hline R\&D & 1.250 & 3.003 & $0.003^{* *}$ & 1,483 & 0.148 \\
\hline PTTIE*ME & -0.077 & -12.23 & $0.000^{* *}$ & (-) 2.295 & $0.014^{*}$ \\
\hline $\mathrm{MB}$ & 0.007 & 0.793 & 0.428 & 2.452 & $0.009^{* *}$ \\
\hline PTTIE*PC & -1.022 & -83.06 & $0.000^{* *}$ & (-) 3.394 & $0.000^{* *}$ \\
\hline $\mathrm{PC}$ & -0.609 & -26.25 & $0.000^{* *}$ & $(-6.769$ & $0.000^{* *}$ \\
\hline PTTIE*STR & -6.593 & -116.9 & $0.000 * *$ & (-) 38.62 & $0.000^{* * *}$ \\
\hline STR & 0.578 & 7.088 & $0.000^{* *}$ & 93.09 & $0.000^{* * *}$ \\
\hline$R$-square & & 0.966 & $\begin{array}{r}0.966 \\
\text { (adjusted) }\end{array}$ & 0.874 & $\begin{array}{r}0.873 \\
\text { (adjusted) }\end{array}$ \\
\hline$F$-statistic & & 26,706 & $\begin{array}{r}0.000^{* *} \\
\text { (p-value) }\end{array}$ & 743.9 & $\begin{array}{r}0.000^{* *} \\
\text { (p-value) }\end{array}$ \\
\hline
\end{tabular}

For variable definitions, see chapter 4 .

$*$ : Significant at the $5 \%$-level

**: Significant at the $1 \%$-level 
Table 3 shows some interesting results. First, the implicit tax relationship in itself is very strong (indicated by the high R-square of the model and highly significant t-/F-values of the PTTIE variable compared to earlier (US) research). Second, the additional variables included to capture tax arbitrage inhibiting factors are in most cases also significant. This indicates that, in general, differences in product and factor market competition do affect the implicit taxes relationship. The results for the STR variable indicate that differences in statutory tax rates also have an impact on the implicit taxes relationship. Furthermore, additional sensitivity analyses in chapter 4 , indicates a significant implicit taxes relationship in each of the 15 European Union member states, with support for the significance of product and factor market proxies in most countries.

\subsection{The use of financial statement data}

Corporate tax researchers can use a plethora of data including, but not limited to:

- Macro-economic data (e.g., OECD's national accounts);

- Micro-economic data (e.g., tax return data);

- Accounting data (e.g., financial statements);

- $\quad$ Simulation type data (e.g., King-Fullerton model).

This dissertation only uses accounting data from financial statements. Financial statement data have particular attributes that provide advantages and disadvantages to investigate the research questions set out in chapter 1 of this dissertation. With regard to the specific research questions in this dissertation, financial statement data have the following advantages:

- Data are publicly available, also on CD-ROM databases;

- Data on both listed and non-listed companies are available;

- Data are structured according to the national Generally Accepted Accounting Principles (GAAP), reducing differences in reporting format;

- Data provide company-specific information;

- Both tax and non-tax information is available.

On the other hand, financial statement data also have some specific disadvantages, including:

- National GAAPs still leave leeway in reporting of data, reducing the comparability of data;

- Not all relevant information is always available, thereby limiting the use of financial statement data. 
Overall though, the use of financial statement data provides unique opportunities to measure (explicit and implicit) tax burdens at the company level. At the same time though, the disadvantages of financial statement data should be kept in mind, especially when interpreting the initial results of statistical analyses. For this reason, this dissertation uses different statistical techniques to test the hypotheses and filters the data to remove extreme observations.

\subsection{Strengths and weaknesses}

Apart from the specific attributes of financial statement data, noted in the preceding paragraph, the empirical chapters in this dissertation have a number of strengths and weaknesses that should be noted here. Strengths include:

- The use of data for the European Union and the Netherlands, where most previous research has used US data;

- Representation of actual (explicit and implicit) tax burdens by using financial statement data, in contrast to, for instance, simulation based data;

- Expansion of the scope of earlier empirical work on, for instance, determinants of ETRs and implicit tax causing variables;

- By means of the statistical designs used, information is provided on the country-specific attributes of fiscal policy.

Some of the weaknesses of the empirical chapters include:

- The used ETRs are not the actual taxes paid, but are reported tax expenses (see also the preceding paragraph);

- Due to data limitations, not all variables could be tested in all settings;

- Due to the European Union setting of two studies, not all specific fiscal country attributes could be incorporated in the research designs.

Despite these weaknesses, the empirical studies still provide a unique insight in the levels of explicit and implicit tax burdens in the Netherlands and the European Union, a geographical area that has not extensively been investigated in previous empirical research with a focus on corporate income taxes. 


\subsection{Conclusion and implications}

At the end of this dissertation some conclusions and implications can be made. First, all research methodologies in the three empirical chapters were based on financial statement data. The use of this particular kind of data has specific advantages and disadvantages as mentioned in paragraph 5.3. One particular advantage is the additional insight offered compared to other data sources by using company-level data. Policy setters often use simulation based data to make tax policy changes (e.g., European Commission 2001). Such data may however provide an incomplete representation of tax burdens as specific company environment attributes cannot be taken into account. Financial statement information, however, does include such information. This implies that, to provide a comprehensive representation, policy setters should also use financial statement information.

Second, the statistical results in chapter 2 showed large variations in STRs and ETRs, as well as in STR/ETR differences. A closer examination of STR and ETR levels showed that the spread of ETRs was not smaller than the spread of STRs, thus providing no evidence for a "tax race to the bottom". Much of the evidence of for this "tax race to the bottom" has been based on declining STRs in the European Union. However, at the same time, taxable incomes have been broadened, keeping effective levels of taxation at about the same levels. Such trends cannot be discerned by solely examining STRs. ETRs have to be used for this. The implication for policy setters and other parties interested in examining tax burdens, is that they should investigate effective levels of tax burdens and not just STRs.

Third, the examination of (possible) determinants of ETRs in the Netherlands showed that there is a relatively small difference between STR and ETR. The associations between company characteristics and ETRs, although present in some cases, explain only a small portion of the STR-ETR difference. In general these results indicate that the levying of corporate income taxes is fairly neutral in the Netherlands, with only a small association between capital intensity/leverage and ETRs.

Fourth, in chapter 4 , the implicit taxes framework was tested in the European Union setting. The statistical results indicate a strong implicit taxes relationship across the European Union, but also for the individual EU member states. The results, in general, also provide significant support for the effects of tax arbitrage inhibiting factors, especially product and factor market competition proxies. Furthermore, differences in STRs affect the implicit taxes relationship. 


\subsection{Directions for future research}

Although this dissertation has tried to examine (determinants of) explicit and implicit corporate tax burden in the Netherlands and the European Union, it certainly has not answered all research questions that might be addressed. Below, for the general research methodology and the three different research questions, some suggestions for future research are made.

\section{Research methodology}

The research methodology in this dissertation has used financial statement data. To (i) enhance the scope of these data, and (ii) test their reliability, these data should be compared with (confidential) tax return data. So far, only one (Dutch) study (Belastingdienst 1997) has examined actual corporate income tax return data. This study did, however, not directly relate consolidated financial statement data to tax return data.

\section{ETRs in the European Union}

Both from a management accounting perspective as well as from a financial accounting perspective, different research questions could be investigated. From a management accounting perspective, it would be very interesting to assess the influence of STRs and ETRs on location decisions of companies within the European Union. To a limited degree, this research question has been investigated by using a questionnaire design. However, the interaction itself between STRs/ETRs, management and location choice has not comprehensively been investigated in the European Union. From a financial accounting perspective, it would be very interesting to develop a measure of the attributes of national tax systems in the European Union that indicate to what extent governments provide tax incentives. In other words, a measure to summarize the relative "fairness" of the corporate income tax.

\section{Determinants of Dutch ETRs}

Although previous empirical research relating company characteristics to ETRs has found mixed results, this might partially be caused by the ability of companies to "manage" their accounting numbers. This is partially taken into account in the empirical setting, by using alternative ETR measures. However, it might be useful to relate the relevant accounting data to the matching cash flow data, providing additional proof on the comparability of accounting data. 


\section{Implicit taxes}

The amount of empirical research on implicit taxes in the corporate sector has, so far, been limited. One of the main reasons for this (Callihan and White 1999 ) is the question as to how implicit taxes should be measured. A limited amount of definitions have so far been used, but there is no agreement yet on the best measure. It would therefore be very useful to examine and test the different implicit taxes measures as to what a good implicit taxes measure is. 


\section{references}

Anderson, M.C., R.D. Banker, and S.N. Janakiraman, 2003, Are Selling, General, and Administrative Costs "Sticky"?, Journal of Accounting Research, Vol. 41, No. 1, pp. 47-63.

Atkinson, A.B., and J. E. Stiglitz, 1980, Lectures on public economics, McGraw-Hill, London.

Ballas, A., and D. Hevas, 1999, Determinants of the Cross Section Variability in Corporate Effective Tax Rates: Some Further Evidence, paper presented at the 22nd annual congress of the European Accounting Association, Bordeaux.

Bartelsman, E.J., and M. Doms, 2000, Understanding Productivity: Lessons from Longitudinal Microdata, The Journal of Economic Literature, Vol. 38, No. 3, pp. 569-594.

Belastingdienst, 1997, Verschillen tussen de fiscale en vennootschappelijke jaarrekening, Ministerie van Financiën, Directoraat-Generaal der Belastingen, Platform Versterking Vaktechniek, Den Haag.

Bond, S., and L. Chennells, 2000, Corporate Income Taxes and Investment: A Comparative Study, The Institute for Fiscal Studies, London.

Bowen, R.M., L. DuCharme, and D. Shores, 1995, Stakeholders' Implicit Claims and Accounting Method Choice, Journal of Accounting and Economics, Vol. 20, No. 3, pp. 255-295.

Buijink, W., B. Janssen, and Y. Schols, 1999, Corporate Effective Tax Rates in the European Union, MARC research report, Maastricht. 
Buijink, W., B. Janssen, and Y. Schols, 2000a, Effective Tax Rates for Mediumsized Companies in EU-countries, MARC research report, Maastricht.

Buijink, W., B. Janssen, and Y. Schols, 2000b, Effective Tax Rates for Listed Companies in OECD-countries, MARC research report, Maastricht.

Buijink, W., B. Janssen, and Y. Schols, 2001, Corporate Tax Competition in the $E U$, MARC research report, Maastricht.

Buijink, W., B. Janssen, and Y. Schols, 2002, Evidence of the Effect of Domicile on Corporate Average Effective Tax Rates in the European Union, Journal of International Accounting, Auditing \& Taxation, Vol. 11 , No. 2, pp. 115-130.

Callihan, D.S., 1994, Corporate Effective Tax Rates: A Synthesis of the Literature, Journal of Accounting Literature, Vol. 13, pp. 1-43.

Callihan, D.S., and R.A. White, 1999, An Application of the Scholes and Wolfson Model to Examine the Relation Between Implicit and Explicit Taxes and Firm Market Structure, The Journal of the American Taxation Association, Vol. 21, No. 1, pp. 1-19.

Caseley, R., 1998, Greece, in Alexander, D., and S. Archer, editors, European accounting guide, Harcourt Brace \& Company, San Diego, pp. 462-521.

Chennells, L., and R. Griffith, 1997, Taxing profits in a changing world, The Institute for Fiscal Studies, London.

Clark, P., 1994, European financial reporting: Luxembourg, Routledge, London.

Cloyd, C.B., J. Pratt, and T. Stock, 1996, The Use of Financial Accounting Choice to Support Aggressive Tax Positions: Public and Private Firms, Journal of Accounting Research, Vol. 34, No. 1, pp. 23-44.

Cnossen, S., 1996, Reform and Harmonization of Company Income Tax Systems in the European Union, Research Memorandum 9604, OCFEB, Erasmus Universiteit Rotterdam.

Cnossen, S., 2001, Fiscal Policy in Action-Tax policy in the European Union: A Review of Issues and Options, FinanzArchiv, Vol. 58, No. 4, pp. 466-558.

Collins, J., and D. Shackelford, 1995, Corporate Domicile and Average Effective Tax Rates: The Cases of Canada, Japan, the United Kingdom and the United States, International Tax and Public Finance, Vol. 2, No. 1 , pp. 55-83. 
Collins, J.H., and D.A. Shackelford, 2001, Did the Tax Cost of Corporate Domicile Change in the 1990s? A Multinational Analysis, working paper.

Conover, W.J., 1980, Practical Nonparametric Statistics, second edition, John Wiley \& Sons, New York.

Conover, W.J., and R.L. Iman, 1981, Rank Transformations as a Bridge Between Parametric and Nonparametric Statistics, The American Statistician, Vol. 35, No. 3, pp. 124-133.

Coopers \& Lybrand, 1998, International tax summaries: a guide for planning and decisions, Coopers \& Lybrand Global Tax Network/Wiley, New York.

Devereux, M., 1989, Tax Asymmetries, the Cost of Capital and Investment: Some Evidence from United Kingdom Panel Data, The Economic Journal, vol. 99, Supplement, pp. 103-112.

Devereux, M., and R. Griffith, 1998, Taxes and the Location of Production: Evidence from a Panel of US Multinationals, Journal of Public Economics, Vol. 68, No. 3, pp. 335-367.

Easson, A., 1993, Taxation in the European Community, Athlone Press, London.

Engel, E., and James R. Hines, 1999, Understanding Tax Evasion Dynamics, NBER working paper, 6903, Cambridge.

Erickson, M., A. Goolsbee, and E. Maydew, 2002, How Prevalent is Tax Arbitrage?: Evidence from the Market for Municipal Bonds, working paper.

Erickson, M.M., and E.L. Maydew, 1998, Implicit Taxes in High Dividend Yield Stocks, The Accounting Review, Vol. 73, No. 4, pp. 435-458.

European Commission, 2001, Company Taxation in he Internal Market, Commission Staff Working Paper, SEC(2001) 1681, Brussel.

European Tax Handbook, 1998, International Bureau of Fiscal Documentation, Amsterdam.

Fama, E.F., and K.R. French, 1996, Multifactor Explanations of Asset Pricing Anomalies, The Journal of Finance, Vol. 51, No. 1, pp. 55-84.

Fama, E.F., and K.R. French, 2000, Forecasting Profitability and Earnings, The Journal of Business, Vol. 73, No. 2, pp. 161-175. 
Feldstein, M., L. Dicks-Mireaux and J. Poterba, 1983, The Effective Tax Rate and the Pretax Rate of Return, Journal of Public Economics, Vol. 21, No. 2,pp. 129-158.

Fernandes Ferreira, L., 1998, Portugal, in Alexander, D., and S. Archer, editors, European accounting guide, Harcourt Brace \& Company, San Diego, pp. 796-877.

Frank, R.H., 1994, Microeconomics and behavior, second edition, McGrawHill, New York.

Gaar, E. van der, and L.G. van der Tas, 1991, in J. Dijksma and C.D. Knoops, editors, De verwerking van belasting naar de winst: Jaar in - jaar uit 5; verslag van een empirisch onderzoek van jaarrapporten over de jaren 1988 en 1989, Wolters-Noordhof, Groningen, pp. 161-184.

Gorter, J., and A. Parikh, 2000, How mobile is Capital within the European Union?, CPB Research Memorandum, The Hague, The Netherlands

Graham, J.R., 1996, Proxies for the Corporate Marginal Tax Rate, Journal of Financial Economics, Vol. 42, No. 2, pp. 187-221.

Greene, W.H., 2002, Econometric Analysis, fifth edition, Prentice Hall.

Goolsbee, A., 1998, Investment Tax Incentives, Prices, and the Supply of Capital Goods, The Quarterly Journal of Economics, Vol. 113, No. 1, pp. 121-148.

Guenther, D.A., and M. Willenborg, 1999, Capital Gains Tax Rates and the Cost of Capital for Small Business: Evidence from the IPO Market, Journal of Financial Economics, Vol. 53, No. 3, pp. 385-408.

Guidelines, 1999, Guidelines for annual reporting in the Netherlands, Kluwer, Deventer, third edition.

Gupta, S., and K. Newberry, 1997, Determinants of the Variability in Corporate Effective Tax Rates: Evidence from Longitudinal Data, Journal of Accounting and Public Policy, Vol. 16, No. 1, pp. 1-34.

Haller, A., 1998, Accounting in Germany, in Walton, P., A. Haller, and B. Raffournier, editors, International accounting, International Thompson, London, pp. 78-107.

Hanlon, M., S. Rajgopol, and T. Shevlin, 2002, Are Executive Stock Options Associated with Future Earnings?, paper presented at the (October) 2002 Journal of Accounting and Economics Conference. 
Harris, D., and R. Sansing, 1998, Distortions Caused by the Use of the Arm's Length Transfer Prices, The Journal of the American Taxation Association, Vol. 20, Supplement, pp. 40-50.

Heurlin, S., and E. Pettersohn, 1998, Sweden, in Alexander, D., and S. Archer, editors, European Accounting Guide, Harcourt Brace \& Company, San Diego, pp. 1076-1131.

Hines, J. R., 1997, Tax policy and the activities of multinational corporations, in A.J. Auerbach, editor, Fiscal policy: Lessons from economic research, MIT Press, Cambridge and London.

Hines, J. R., 1999, Lessons from Behavioral Responses to International Taxation, National Tax Journal, Vol. 52, No. 2, pp. 305-322.

Hoareau, C., 1998, Accounting in France, in Walton, P., A. Haller, and B. Raffournier, editors, International accounting, International Thompson, London, pp. 108-129.

Holland, K., 1998, Accounting Policy Choice: The Relationship between Corporate Tax Burdens and Company Size, Journal of Business Finance \& Accounting, Vol. 25, No. 3-4, pp. 265-288.

Hoogendoorn, M.N., 1996a, Accounting and Taxation in Europe: A Comparative Overview, The European Accounting Review, Vol. 5, Supplement, pp. 783-794.

Hoogendoorn, M.N., 1996b, Accounting and Taxation in the Netherlands, The European Accounting Review, Vol. 5, Supplement, pp. 871-882.

International tax summaries: a guide for planning and decisions, 1998, PriceWaterhouseCoopers, New York.

Janssen, B., and W. Buijink, 1998, Determinants of the Variability of Corporate Effective Tax Rates (ETRs): Evidence for the Netherlands, paper presented at the 21 st annual congress of the European Accounting Association, Antwerp.

Järvenpää, M., 1996, The Relationship between Taxation and Financial Accounting in Finland, The European Accounting Review, Vol. 5, Supplement, pp. 899-914.

Jorissen, A., and L. Maes, 1996, The Principle of Neutrality: The Cornerstone of the Relationship between Financial Reporting in Belgium, The European Accounting Review, Vol. 5, Supplement, pp. 915-932. 
Kampschoër, G., 1997, Belastingen, in M. Hoogendoorn, et. al., Externe verslaggeving in theorie en praktijk, tweede druk, Delwel, Den Haag, pp. 464-499.

Kampschoër, G., 2001, Belastingen, in M. Hoogendoorn, et. al., Externe verslaggeving in theorie en praktijk, derde druk, Delwel, Den Haag, pp. 563-605.

Köthenbürger, M., 2002, Tax Competition and Fiscal Equalization, International Tax and Public Finance, Vol. 9, No. 4, pp. 391-408.

KPMG, 2001, Corporate Tax Rate Survey, January.

Lang, M.H., and R.J. Lundholm, 1996, Corporate Disclosure Policy and Analyst Behavior, The Accounting Review, Vol. 71, No. 4, pp. 467-492.

Maukner, H., 1998, Austria, in Alexander, D., and S. Archer, editors, European Accounting Guide, Harcourt Brace \& Company, San Diego, pp. 29-98.

Messeree, K., 1993, Tax policy in OECD countries: choices and conflicts, International Bureau for Fiscal Documentation, Amsterdam, The Netherlands.

Mills, L.F., and K.J. Newberry, 2001, The Influence of Tax and Nontax Costs on Book-Tax Reporting Differences: Public and Private Firms, The Journal of the American Taxation Association, Vol. 23, No. 1, pp. 1-19.

Mooij, R.A. de, and S. Ederveen, 2001, Taxation and foreign direct investment, $\mathrm{CPB}$, The Hague, memorandum

Mooij, R.A. de, and J. Gorter, 2001, Capital income taxation in Europe: Trend and trade-offs, SDU Uitgevers \& Centraal Planbureau, The Hague.

Musgrave, R.A., 1969, Studies in comparative economics: Fiscal systems, Yale University Press, New Haven.

Musgrave, R.A., and P.B. Musgrave, 1989, Public finance in theory and practice, fifth edition, McGraw-Hill, New York.

Neter, J., Kutner, M.H., C.J. Nachtsheim, and W. Wasserman, 1996, Applied Linear Statistical Models, fourth edition, McGraw-Hill/Irwin, Homewood.

Nicodème, G., 2001, Computing Effective Corporate Tax Rates: Comparison and Results, European Commission, Directorate General for Economic and Financial Affairs, Brussels, working paper. 
Nobes, C., and R. Parker, 2000, Comparative international accounting, Harlow, Financial Times/Prentice Hall, sixth edition

Noord, P. van den, and C. Heady, 2001, Surveillance of tax policies: A synthesis of findings in economic surveys, $\mathrm{OECD}$, Paris.

OECD, 1991, Taxing profits in a global economy: domestic and international issues, $\mathrm{OECD}$, Paris.

Omer, T.C., K.H. Molloy, and D.A. Ziebart, 1991, Measurement of Effective Corporate Tax Rates Using Financial Statement Information, Journal of the American Taxation Association, Vol. 13, No. 1, pp. 57-72.

Pearlman, R.A., 1998, Fresh from the River Styx: The Achilles' Heels of Tax Reform Proposals, National Tax Journal, Vol. 51, No. 3, pp. 569-578.

Plesko, G.A., 2003, An Evaluation of Alternative Measures of Corporate Tax Rates, Journal of Accounting and Economics, Vol. 35, No. 2, pp. 201226.

Porcano, T., 1986, Corporate Tax Rates: Progressive, Proportional, or Regressive, Journal of the American Taxation Association, Vol. 7, No. 2, pp. 17-31.

Roberts, M.L., 1998, Tax Accountants' Judgment/decision-making Research: A Review and Synthesis, The Journal of the American Taxation Association, Vol. 20, No. 1, pp. 78-121.

Scherer, F.M., and D. Ross, 1990, Industrial Market Structure and Economic Performance, Houghton Mifflin Company, Boston.

Scholes, M.S., and M.A. Wolfson, 1992, Taxes and business strategy: A planning approach, Prentice Hall, Englewood Cliffs.

Shackelford, D.A., and T. Shevlin, 2001, Empirical Tax Research in Accounting, Journal of Accounting and Economics, Vol. 31, No. 1-3, pp. 321-387.

Shevlin, T., 1999, Research in Taxation, Accounting Horizons, Vol. 13, No. 4, pp. 427-441.

Shevlin, T., and S. Porter, 1992, The Corporate Tax Comeback in 1987: Some Further Evidence, Journal of the American Taxation Association, Vol. 14, No. 1, pp. 58-79. 
Shields, M., I. Solomon, and K. Jackson, 1995, Experimental research on tax professionals' judgement and decision making, in J. Davis, editor, Behavioral tax research: Prospects and judgment calls, American Taxation Association, Sarasota.

Single, L. E., 1999, Tax Holidays and Firms' Subsidiary Location Decisions, The Journal of the American Taxation Association, Vol. 21, No. 2, pp. 17 34.

Slemrod, J., and S. Yitzhaki, 2000, Tax avoidance, evasion, and administration, NBER working paper, No. 7473, Cambridge.

Spenke, G. te, 1995, Taxation in the Netherlands, Kluwer, Deventer/Boston.

Stickney, C., and V. McGee, 1982, Effective Corporate Tax Rates: The Effect of Size, Capital Intensity, Leverage, and Other Factors, Journal of Accounting and Public Policy, Vol. 1, No. 2, pp. 125-152.

Stigler, G.J., 1963, Capital and rates of return in manufacturing industries, Princeton University Press, Princeton, N. J.

Stiglitz, J.E., 1997, Economics, second edition, WW Norton \& Company, New York.

Stiglitz, J.E., 2000, Economics of the Public Sector, third edition, W.W. Norton \& Company, New York.

Tas, L.G. van der, 1998, Accounting in the Netherlands, in Walton, P., A. Haller, and B. Raffournier, editors, International accounting; International Thompson, London, pp. 216-229.

Teixeira, G., 1997, Taxing corporate profits in the EU: a comparison of the Portuguese, British and Dutch systems, Kluwer Law International, London.

Tirard, J.M., 1994, Corporate taxation in EU countries, Longman, London.

Verburg, J., 2000, Vennootschapsbelasting, Kluwer, Deventer.

Wang, S., 1991, The Relation Between Firm Size and Effective Tax Rates: a Test of Firms' Political Success, The Accounting Review, Vol. 66, No. 1, pp. $158-169$.

Wilkie, P.J., 1988, Corporate Average Effective Tax Rates and Inferences About Relative Tax Preferences, The Journal of the American Taxation Association, Vol. 10, No. 1, pp. 75-88. 
Wilkie, P, and S. Limberg, 1990, The Relationship between Firm Size and Effective Tax Rate: A Reconciliation of Zimmerman [1983] and Porcano [1986], Journal of the American Taxation Association, Vol. 11, No. 2, pp. 76-91.

Wilkie, P.J., 1992, Empirical Evidence of Implicit Taxes in the Corporate Sector, The Journal of the American Taxation Association, Vol. 14, No. 1, pp. 97-116.

Wilkie, P., and S. Limberg, 1993, Measuring Explicit Tax (Dis)advantage for Corporate Taxpayers: An Alternative to Average Effective Tax Rates, Journal of the American Taxation Association, Vol. 15, No. 1, pp. 46-71.

Wilson, J.D., 1999, Theories of Tax Competition, National Tax Journal, Vol. 52, No. 2, pp. 269-304.

Zambon, S., 1998, Accounting in Italy, in Walton, P., A. Haller, and B. Raffournier, editors, International accounting, International Thompson, London, pp. 181-215.

Zeff, S., F. van der Wel, K. Camfferman, 1992, Company Financial Reporting: a historical and comparative study of the Dutch regulatory process, Elsevier Science Publishers, Amsterdam.

Zimmerman, J., 1983, Taxes and Firm Size, Journal of Accounting and Economics, Vol. 5, No. 2, pp. 119-149. 


\section{summary in Dutch}

\section{(Nederlandstalige samenvatting)}

\section{Empirical Evidence on Explicit and Implicit Corporate Tax Burdens: Three Studies \\ (Empirische Resultaten van Onderzoek naar Expliciete en Impliciete Vennootschapsbelastingdruk: Drie Studies)}

Het doel van dit proefschrift is om (determinanten van) de expliciete en impliciete vennootschapsbelastingdruk op ondernemingen in Nederland en de Europese Unie te onderzoeken. Hiertoe zijn in dit proefschrift drie studies opgenomen:

Een empirisch onderzoek naar de expliciete vennootschapsbelastingdruk op ondernemingen met hun domicilie in de Europese Unie. Het doel van deze eerste empirische studie is om na te gaan wat de verschillen zijn tussen de vennootschapsbelastingdruk op ondernemingen in de lidstaten van de Europese Unie. Voor de berekening van de vennootschapsbelastingdruk wordt hierbij gebruik gemaakt van gegevens uit jaarrekeningen.

Een empirisch onderzoek naar de determinanten van vennootschapsbelastingdruk op ondernemingen met hun domicilie in Nederland. In deze studie wordt gekeken naar die karakteristieken van Nederlandse ondernemingen die hun vennootschapsbelastingdruk kunnen beïnvloeden. Voor de berekening van de ondernemingskarakteristieken wordt gebruik gemaakt van gegevens uit jaarrekeningen.

Een empirisch onderzoek naar de impliciete vennootschapsbelastingdruk op ondernemingen met hun domicilie in de Europese Unie. Bij deze laatste studie wordt het impliciete belastingen model, zoals ontwikkeld door Scholes en Wolfson (1992), getest op ondernemingen in de Europese Unie. Ook bij deze studie wordt gebruik gemaakt van gegevens uit jaarrekeningen.

Hoofdstuk 1 van dit proefschrift geeft aan hoe de drie onderzoeken in dit proefschrift geplaatst kunnen worden binnen de onderzoeksliteratuur. Hiertoe 
wordt er in dit eerste hoofdstuk onderscheid gemaakt tussen verschillende soorten onderzoek op een aantal dimensies, namelijk:

- Belastingen: Welke belastingen zijn er binnen de classificaties directe en indirecte belastingen? In dit proefschrift wordt enkel ingegaan op de vennootschapsbelasting, een vorm van directe belastingen.

- Onderzoeksgebieden: Hier wordt een onderscheid gemaakt tussen de gebieden algemene economie, bedrijfseconomie en rechten. Het onderzoek in dit proefschrift vindt met name plaats op het gebied van de bedrijfseconomie, hoewel er ook duidelijke relaties zijn met algemene economie en rechten.

- Onderzoeksdomeinen: Het onderzoeksdomein vennootschapsbelasting binnen de bedrijfseconomie kan onderverdeeld worden in drie domeinen: naleving, planning en beleid, waarbij belastingplanning het belangrijkste domein van dit proefschrift vormt. In het bijzonder wordt er binnen de belastingplanning ingegaan op de vennootschapsbelastingdruk.

- Vennootschapsbelastingdruk: Deze kan op twee algemene manieren worden gemeten: door middel van een gemiddelde of marginale belastingdruk. De gemiddelde belastingdruk geeft hierbij met name een indicatie van de rechtvaardigheid ("equity") van belastingheffing, terwijl de marginale belastingdruk meer een indicatie geeft van de doelmatigheid ("efficiency") van belastingheffing.

- Methodologie: In de bestaande empirische literatuur wordt een drietal methodologieën gebruikt: macro retrospectief, micro retrospectief en micro prospectief. Bij de macro retrospectieve methodologie wordt gebruik gemaakt van historische macro-economische data. In tegenstelling hiermee wordt bij de micro retrospectieve methode gebruik gemaakt van historische micro-economische data, terwijl bij de micro prospectieve methodologie gebruik wordt gemaakt van toekomstgeoriënteerde micro-economische data. Bij de drie genoemde methodologieën kan in een aantal gevallen onderscheid worden gemaakt tussen een empirische en een theoretische meting. Bij een empirische meting wordt gebruik gemaakt van empirische data, terwijl bij een theoretische meting vaak gebruik wordt gemaakt van een simulatie gebaseerd op verschillende scenario's. Binnen dit proefschrift wordt er gebruik gemaakt van de micro retrospectieve methodologie met een empirische meting.

Hoofdstuk 2 van dit proefschrift bevat een empirische studie naar de expliciete vennootschapsbelastingdruk op ondernemingen met hun domicilie in de Europese Unie. Het doel van deze studie is om inzicht te geven in de relatieve "concurrentie" positie van een land met betrekking tot de vennootschapsbelasting. Landen hebben immers tal van mogelijkheden om hun 
vennootschapsbelastingsysteem attractiever te maken voor bedrijven en maken daar in de praktijk ook frequent gebruik van, zoals ondermeer blijkt uit de discussies binnen Europese Unie (EU) en Organisatie voor Economische Samenwerking en Ontwikkeling (OESO) verband over schadelijke belastingconcurrentie. $\mathrm{Om}$ de relatieve vennootschapsbelastingdruk te meten, kunnen verschillende maatstaven worden gebruikt. Vaak wordt gebruikt gemaakt van het wettelijke vennootschapsbelastingtarief. Dit tarief houdt echter geen rekening met belastingprikkels die landen aan bedrijven kunnen verschaffen. Een maatstaf die hier wel rekening mee houdt is de effectieve belastingdruk (EBD), gedefinieerd als gerapporteerde belastingkosten gedeeld door winst voor belasting (Callihan 1994). Een vergelijking van de EBD met het wettelijke belastingtarief geeft informatie over de relatieve omvang van belastingprikkels die verschaft worden door (nationale) overheden.

In hoofdstuk 2 wordt de wettelijke en effectieve belastingdruk onderzocht voor de 15 Europese Unie lidstaten. Voor het verkrijgen van de data wordt gebruik gemaakt van informatie uit jaarrekeningen, zoals opgenomen op de CDROM database Worldscope. Omdat er verschillende externe verslaggevingsformaten in de Europese Unie lidstaten worden gebruikt, worden drie verschillende EBD-definities gebruikt. De eerste EBD-definitie komt overeen met de definitie zoals hierboven weergegeven, terwijl bij de tweede EBD-definitie netto omzet in de noemer wordt gebruikt in plaats van winst voor belasting. De laatste, derde, EBD-definitie gebruikt enkel de huidige belastingkosten (belastingkosten - dotatie voorziening latente belasting) in de teller, gedeeld door winst voor belasting in de noemer. Om jaar tot jaar verschillen tussen externe verslaggevingsdata en extreme data zoveel mogelijk te vermijden, zijn er twee maatregelen genomen met betrekking tot de steekproef:

- De steekproef is afkomstig uit meerdere jaren, hierbij is gebruik gemaakt van de meest recente jaren die beschikbaar waren binnen de gebruikte Worldscope database versie, dit waren de jaren 1990-1996;

- De steekproef is gefilterd; hierbij zijn alle EBD waarnemingen die meer dan twee standaard afwijkingen van het gemiddelde afliggen verwijderd.

Deze maatregelen beperken weliswaar de omvang van de steekproef, maar verhogen anderzijds de betrouwbaarheid van de uitkomsten van de statistische analyses. De initiële steekproef bestaat uit 2.958 bedrijven met 20.706 bedrijfswaarnemingen en laat zien dat het aantal bedrijven sterk varieert per land. Terwijl er voor Griekenland en Luxemburg slechts enkele ondernemingen in de steekproef aanwezig zijn, telt het Verenigd Koninkrijk ruim twee duizend ondernemingen. Uit de analyses van het wettelijke belastingtarief en de verschillende EBD-tarieven blijken grote verschillen tussen landen. Indien op basis van de eerste definitie van de EBD het verschil tussen 
het wettelijke en effectieve tarief wordt onderzocht, blijkt dat een aantal landen (zoals Zweden, Frankrijk en Nederland) een klein verschil heeft, terwijl andere landen (zoals Oostenrijk, België en Portugal) een (veel) groter verschil hebben. Dit verschil loopt op tot circa 20 procentpunten voor de laatst genoemde landen. Hoewel de resultaten van de twee andere EBD-definities enigszins afwijken, blijken ook uit deze definities grote verschillen tussen landen. Om na te gaan of er in de EBD minder variatie is dan in het wettelijke tarief (conform de gedachten van een "tax race to the bottom"), is gebruik gemaakt van de "coefficient of variation". Op basis van analyses van deze "coefficient of variation" kan niet worden gesteld dat de variatie in EBD kleiner is dan de variatie in het wettelijke belastingtarief.

Uit de analyses in hoofdstuk 2 komen dus grote verschillen tussen landen in EBD en wettelijk belastingtarief naar voren, maar geen directe bewijzen voor een "tax race to the bottom", waarin de EBDen van de Europese Unie lidstaten naar een lager niveau zouden moeten tenderen.

Hoofdstuk 3 van dit proefschrift is een onderzoek naar de determinanten van de EBD in Nederland. Hierbij wordt in het bijzonder gekeken naar ondernemingsspecifieke factoren die van invloed kunnen zijn op de relatieve hoogte van de EBD. Uit eerder Amerikaans onderzoek komt namelijk naar voren dat verschillende ondernemingskenmerken (zoals ondernemingsgrootte en kapitaalintensiteit) een invloed kunnen hebben op de EBD. Overheden gebruiken immers vaak belastingprikkels om ondernemingen te sturen in hun economische gedragingen.

De vraag in dit hoofdstuk is, in hoeverre dit ook in Nederland het geval is. Op basis van het genoemde onderzoek en de specifieke attributen van de Nederlandse vennootschapsbelasting zijn een zestal ondernemingskarakteristieken opgenomen in het empirische model. Voor de steekproef is gebruik gemaakt van de CD-ROM database $R E A C H$ die de gegevens bevat van Nederlandse jaarrekeningen. Op basis van een zestal selectiecriteria is er een steekproef geselecteerd. Om rekening te houden met extreme waarnemingen en jaar tot jaar verschillen in de externe verslaggevingsdata is er gebruik gemaakt van een steekproef voor de jaren 1994-1999 en zijn de EBD data gefilterd op twee standaard deviaties van het gemiddelde. Tevens zijn er twee EBD definities gebruikt. Bij de eerste definitie is EBD gedefinieerd als huidige belastingkosten (totale belastingkosten - dotatie aan voorziening latente belastingen) gedeeld door winst voor belasting, terwijl bij de tweede definitie, EBD is gedefinieerd als huidige belastingkosten gedeeld door kasstroom. Zowel univariate als multivariate analyses zijn gebruikt om de steekproef te onderzoeken. Uit deze analyses komt naar voren dat er een relatief klein verschil is tussen EBD en het nominale belastingtarief. Dit (kleine) verschil kan voor slechts een zeer klein gedeelte worden toegerekend aan ondernemingskarakteristieken. Zowel kapitaalintensiteit als de verhouding tussen vreemd en eigen vermogen zijn 
negatief geassocieerd met EBD. Zoals reeds eerder aangegeven, kan deze associatie echter slechts een klein gedeelte van de verschillen in EBD verklaren. Op basis van deze resultaten kan gesteld worden dat de heffing van de vennootschapsbelasting op een relatief neutrale wijze plaatsvindt. Om na te gaan of deze resultaten ook robuust zijn bij andere modelspecificaties, zijn verschillende additionele analyses verricht. Deze analyses bevestigen de eerdere bevindingen.

Hoofdstuk 4, het laatste empirische hoofdstuk, onderzoekt impliciete belastingen in de Europese Unie. Overheden maken gebruik van belastingprikkels om het gedrag van ondernemingen te sturen. Deze belastingprikkels zullen de winst $n a$ belasting verhogen ten opzichte van investeringen waaraan geen (of minder) belastingprikkels verschaft worden. Door middel van "arbitrage" zullen de rendementen voor belasting van deze lager belaste investeringen omlaag moeten gaan, zodat de rendementen na belastingen van verschillende belaste investeringen gelijk zullen zijn. De verschillen in rendementen voor belasting van verschillend belaste investeringen worden impliciete belastingen genoemd. Dit alles onder het voorbehoud van een gelijk risiconiveau en de afwezigheid van fricties.

In dit hoofdstuk wordt expliciete aandacht geschonken aan de fricties die de werking van "arbitrage" kunnen bemoeilijken. Hiertoe zijn een aantal proxies voor product en factor markten opgenomen. Voor het meten van de impliciete belastingen zelf is aangesloten bij eerder onderzoek. De steekproef is verzameld uit de CD-ROM database Osiris die de jaarrekeningen van ondernemingen uit de Europese Unie bevat. Diverse univariate en multivariate modelspecificaties zijn gebruikt om te onderzoeken in welke mate impliciete belastingen aanwezig zijn in de Europese Unie. Indien er geen verstorende factoren zouden zijn, zou de coëfficiënt voor het verband tussen PTROE (proxy voor winst voor belasting) en PTTIE (proxy voor impliciete belastingen) -1 moeten zijn $\left(\mathrm{R}^{2}=\right.$ $100 \%$ ). Uit de resultaten komt een relatief sterk model naar voren dat circa $90 \%$ van de variatie van PTROE verklaart, duidelijk meer dan in eerder onderzoek. Uit de resultaten komt ook naar voren dat de proxies voor product- en factormarkten een significante invloed hebben op de impliciete belasting relatie. Voorts hebben verschillen in statutaire belastingtarieven ook een invloed op de sterkte van de impliciete belasting relatie.

Hoofdstuk 5 rondt dit proefschrift af. In dit hoofdstuk wordt onder andere aandacht besteedt aan:

- Het gebruik van externe verslaggevingsdata;

- De sterktes en zwaktes van de empirische studies;

- Implicaties van de resultaten van de empirische studies. 
Alle drie de empirische studies in dit proefschrift maken gebruik van externe verslaggevingsdata. Zulke data heeft specifieke voor- en nadelen vergeleken met andere databronnen. Een van de belangrijkste voordelen is de beschikbaarheid van data voor een groot aantal ondernemingen. Een belangrijk nadeel is dat door de verschillen in externe verslaggeving, de data niet volledig met elkaar te vergelijken is. Dit is tevens een zwakte van de gekozen onderzoeksopzet in dit proefschrift. Tot de sterktes van dit proefschrift behoren het gebruik van data over Europese Unie landen en data die een representatie geven van de werkelijke belastingdruk in tegenstelling tot bijvoorbeeld simulatiedata.

Op basis van de resultaten van de empirische hoofdstukken kunnen een viertal implicaties worden gemaakt. Ten eerste gebruiken beleidsmakers vaak macro-economische data. Dit soort data mist het detail van micro-economische data zoals deze in dit proefschrift wordt gebruikt. Beleidsmakers zouden er dan ook goed aan doen om dit soort data ook te gebruiken om hun beslissingen op te baseren. Op de tweede plaats dient bij onderzoek naar de belastingdruk niet enkel gekeken te worden naar het wettelijke belastingtarief, maar ook naar de EBD. De EBD is immers de resultante van wettelijk belastingtarief en verschafte belastingprikkels. De derde implicatie is dat het algemene niveau van verschafte belastingprikkels redelijk laag is, maar dat deze belastingprikkels wel gerelateerd zijn aan winstgevendheid (positief) en kapitaalintensiviteit (negatief). Laatste en vierde implicatie is dat verschafte belastingprikkels het niveau van winst voor belasting beïnvloeden, maar dat daarnaast ook product en factor markt variabelen de impliciete belastingen relatie beïnvloeden. 


\section{curriculum vitae}

Boudewijn Janssen was born on March 26, 1972 in Maastricht. From 1985 until 1991, he attended grammar school at Stella Maris College in Meerssen. Subsequently, from 1991 to 1996, he studied Business Administration at Universiteit Maastricht. Starting in 1996, he worked as a lecturer at the Accounting department of Universiteit Maastricht. As of 1998, the position was changed to assistant professor. From 1999 until 2002, he was also project coordinator of a MARC research project. During 2000, he spent three months as a visiting scholar at the accounting department of The University of Arizona.

Boudewijn Janssen is op 26 maart 1972 geboren in Maastricht. Gedurende de jaren 1985-1991 ging hij naar middelbaar onderwijs op het Stelle Maris College in Meerssen. Vervolgens studeerde hij van 1991 tot en met 1996 bedrijfseconomie aan de Universiteit Maastricht. In 1996 begon hij als docent aan het departement accounting van de Universiteit Maastricht. Met ingang van 1998 werd hij benoemd tot universitair docent. Van 1999 tot en met 2002 was hij daarnaast ook project coördinator van een MARC onderzoeksproject. Gedurende 2000 verbracht hij drie maanden aan het departement accounting van The University of Arizona. 
